
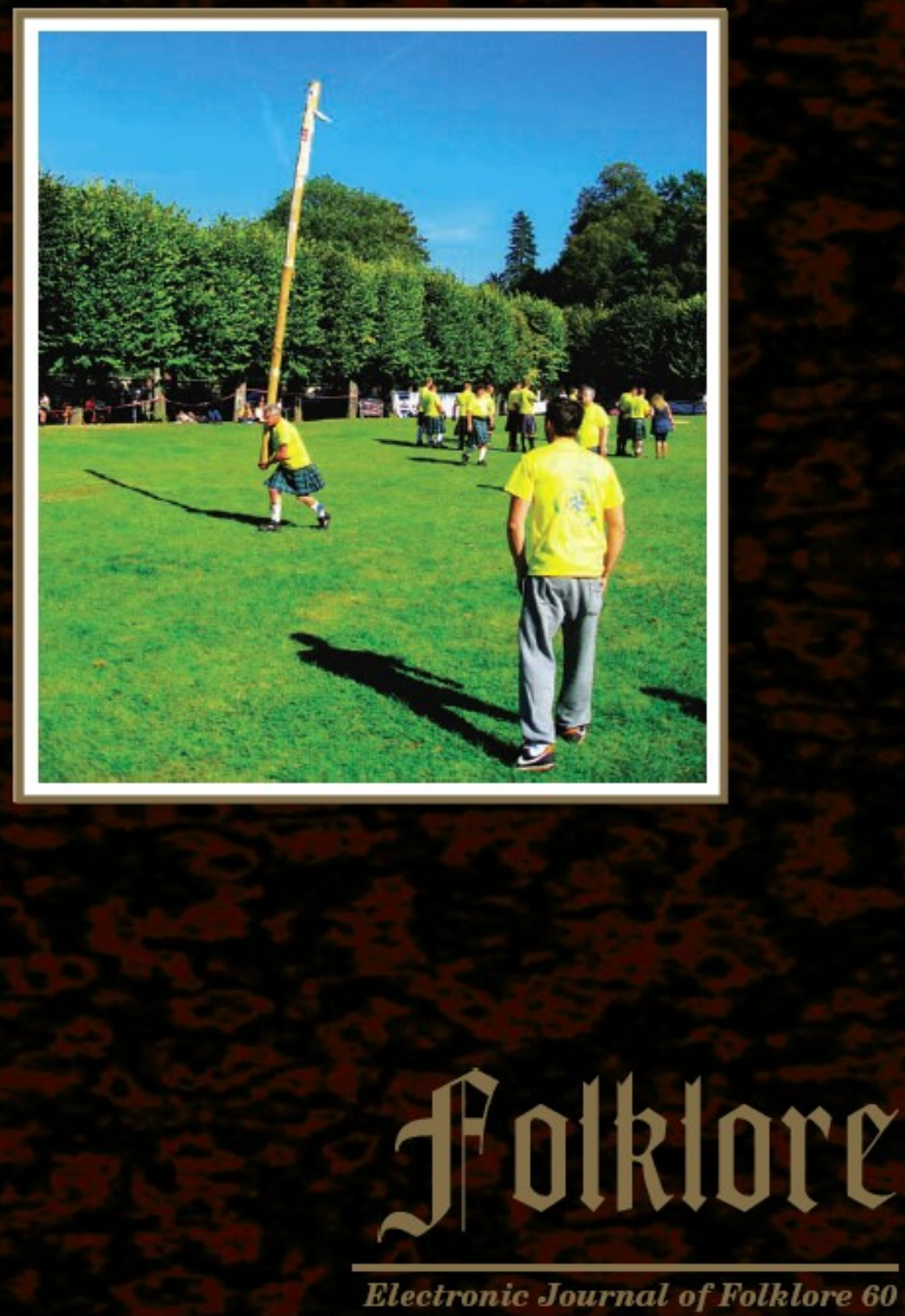


\section{Folklore}

Electronic Journal of Folklore

http://www.folklore.ee/folklore Printed version

Vol. 60

2015 
Folk Belief and Media Group of the Estonian Literary Museum

Estonian Institute of Folklore

\section{Folklore}

Electronic Journal of Folklore Vol. 60

Edited by Mare Kõiva \& Andres Kuperjanov Guest editors: Laurent Sébastien Fournier \& Irina Sedakova

Tartu 2015 
Editor in chief

Co-editor

Guest editors:

Copy editor

News and reviews

Design

Layout
Mare Kõiva

Andres Kuperjanov

Laurent Sébastien Fournier \& Irina Sedakova

Tiina Mällo

Piret Voolaid

Andres Kuperjanov

Diana Kahre

Editorial board 2015-2020: Dan Ben-Amos (University of Pennsylvania, USA), Larisa Fialkova (University of Haifa, Israel), Diane Goldstein (Memorial University of Newfoundland, Canada), Terry Gunnell (University of Iceland), Jawaharlal Handoo (University of Mysore, India), Frank Korom (Boston University, USA), Jurij Fikfak (Institute of Slovenian Ethnology), Ülo Valk (University of Tartu, Estonia), Wolfgang Mieder (University of Vermont, USA), Irina Sedakova (Russian Academy of Sciences).

The journal is supported by the institutional research funding IUT22-5, the state programme project EKKM14-344, and the Estonian Literary Museum.

Indexed in EBSCO Publishing Humanities International Complete, Thomson Reuters Arts \& Humanities Citation Index, MLA International Bibliography, Ulrich's Periodicals Directory, Internationale Volkskundliche Bibliographie / International Folklore Bibliography / Bibliographie Internationale d'Ethnologie), DOAJ, C.E.E.O.L., ERIH (B), Scopus

\section{Editorial address:}

Folklore: Electronic Journal of Folklore

Vanemuise 42-235

51003 Tartu

Estonia

phone: $\quad+3727377740$

fax: $\quad+3727377706$

e-mail: folklore@folklore.ee

home page: http://www.folklore.ee/folklore

All rights reserved

(C) Folk Belief and Media Group of the Estonian Literary Museum

EKM Teaduskirjastus / ELM Scholarly Press

Estonian Institute of Folklore

Authors

Design Andres Kuperjanov

ISSN 1406-0957

doi:10.7592/FEJF2015.60 


\section{CONTENTS}

Introduction: Differentiation of Ritual Year(s) through Time

and Space

Laurent Sébastien Fournier, Irina Sedakova

Circulation and Differentiation of Scottish Games and Sports

Laurent Sébastien Fournier

A Festive Bricolage: The Holiday Calendar in Slovenia

Over the Last Century

Ingrid Slavec Gradišnik

Political Rituals and Discourses: The Case of Carinthia

Jurij Fikfak

Politicising St. Martin and Constructing Heritage:

A Case Study of a Small Town in Croatia

Juraj Belaj, Marijana Belaj, Petra Kelemen, Filomena Sirovica

The Age-Old Cossack Feast of the Protecting Veil:

A Contemporary Interpretation of a Traditional Calendar Date

Nina Vlaskina

Užgavėnès: A Rural and Urban, Religious, Socialist, and Lithuanian Festival of Shrovetide

Žilvytis Šaknys

In MEMORIAM

Ülo Tedre. Arvo Krikmann

NEWS IN BRIEF

Magic in the Ritual Year. Irina Sedakova

Natalia Ermakov Defended a Doctoral Thesis on Erzya Lamentations.

Ingrid Rü̈̈tel 
Seminar on Digital Humanities at the Estonian Literary Museum:

Infotechnological Innovation in Humanities and Education. Kaisa Kulasalu

Estonian Folklore, Cultural History and Literature in a Digital Form:

The File Repository and Archival Information System Kivike. Kaisa Kulasalu

International Winter School "Circulation and Collaboration: Perspectives

for/in Interdisciplinarity”. Reet Hiiemäe, Kristin Kuutma

\section{BOOK REVIEWS}

Travels of an Exiled Writer. Aimar Ventsel

146

Islamic Civilisation and Muslim Networks. Aimar Ventsel

148 


\title{
INTRODUCTION: DIFFERENTIATION OF RITUAL YEAR(S) THROUGH TIME AND SPACE
}

\author{
Laurent Sébastien Fournier, Irina Sedakova
}

The idea of this issue of Folklore: Electronic Journal of Folklore originated in a panel that we presented at the 11th congress of the Société Internationale d'Ethnologie et de Folklore (SIEF) held in Tartu, Estonia, in July 2013. During the panel meeting we focused on the differentiation of the ritual year and its various elements. After nearly ten years of research and conferences, ${ }^{1}$ we identified the ritual year as a general frame within which calendrical rituals, festivals, and other cultural performances take place and can easily be studied and interpreted. The idea of the ritual year has proved to be productive as it enables collaborative and interdisciplinary research with no historical or geographical limits. Not only folklorists and ethnologists, but also archaeologists, linguists, sociologists and political scientists can contribute something to the study of the ritual year because the idea of connecting nature and culture seems to be present in all societies throughout all eras of history.

\section{RITUALS IN A GLOBAL WORLD}

Out of general interest in calendars and rituals, we developed a special interest in the ways that, and reasons why, some elements of the traditional ritual years were picked up by individuals or political bodies and selected in order to construct or revive identity, to address the preferences of new audiences in a globalised world, to create or improve the image of a locality, etc. We have become especially interested in the ways that traditional rituals can be adapted and transformed in new social and cultural settings, new historical contexts, or in relation with migrations or other geographical changes.

In a globalised world, with a high rate of migration and crucial political changes in Eastern European countries, we can see that some of the traditional rituals have survived and even developed into huge national festivities, while 
other customs fade away and finally disappear. ${ }^{2}$ In this context, we suggest that globalisation paradoxically leads both to the differentiation and to the fragmentation of traditional rituals. ${ }^{3}$ Therefore, the notion of differentiation can be grasped through the circulation as well as the mobility, adaptation and (re)construction of traditional rituals and festivals through time and space.

By means of case studies and more theoretical reflections, the contributions to this issue of Folklore: Electronic Journal of Folklore enable us to compare the ritual systems across various countries, so as to uncover the reasons for selectivity and differentiation (migrations, ideology, religiosity, national values, local cultural tourist attractions, etc.). Special attention is paid to the ritual year in the former socialist countries, and the cases of other European countries provide valuable material for a comparative analysis. The contributors to this issue also aim to highlight how material about the traditional knowledge and performance habits is collected, studied and circulated nowadays, and how it leads to reinterpretations of the rituals. ${ }^{4}$

\section{CIRCULATIONS, DIFFERENTIATIONS, SELECTIONS}

Three different sets of questions are connected with our topic. Firstly, why do rituals circulate? This question has several answers. Political, ideological (including religious), and economic reasons immediately come to mind when we think about minorities who have to leave their countries to continue performing their rituals, but the circulation of rituals also depends on the taste for novelties, fantasy, and the initiatives of religious leaders or communities. In some cases the political opponents of a regime decide to create their own ritual year with new symbols, emblems and dates, using and adapting rituals that they borrow from other societies or cultural settings. In other cases, old rituals are re-enacted to bring back the memories of a legendary past.

Secondly, how do rituals differentiate in time and space? This question makes us reflect on the rhythms of the differentiation processes. Different rituals can change at a quicker or slower pace according to the context and the dynamics of the cultural systems to which they belong. In some cases the differentiation of the rituals is not even perceptible and people speak about unchanged traditions, but in other cases sudden shifts can occur and totally change the local ritual landscape in a few years' time. The differentiation of rituals is then useful to understand the social changes and evolutions in general.

Thirdly, which elements are selected when rituals circulate? This question is concerned with the adaptability of the different cultural parts of which rituals 
are composed. In the differentiation process, ritual emblems can be re-used with different meanings and new symbols can appear. It is interesting to compare the elements that travel easily from one context to another and the ones that are left behind and progressively forgotten. Selectivity has its own reasons which can be grasped through empirical investigation and reveal both the more and the less powerful charge of the different elements of the rituals.

The question of the differentiation of rituals in time and space eventually appears as a very complex one because it mixes the idea of the global evolution of rituals and the notions of circulation and diffusion. Focusing on the differentiation of the ritual year is also a means to simultaneously study the rituals and their significations. The calendar is a complex meaningful system, and the different sorts of rituals need to be connected with their respective meanings. Looking at the ritual years in the plural, as suggested in the title, opens for investigation new invented rituals and different local celebrations of religious festivals, but also those of national holidays. By means of the notion of differentiation, we then aim to pay attention to the ways that dissimilar rituals still share the same problems when they are confronted with a new context.

\section{THE IMPORTANCE OF CASE STUDIES}

The contributions to this issue of Folklore: Electronic Journal of Folklore provide only a few elements to answer the general questions raised by the differentiation process in which the different rituals worldwide are caught. However, they show the importance of case studies and their usefulness in addressing more general or theoretical problems.

All the cases investigated by the authors are based on various ethnological data and present different views on the circulation, differentiation, and selectivity of the ritual year(s), yet the general reasons for modifications are common and vary only in details.

This volume contains six articles that geographically cover Eastern Europe (Russia), including the south-east (Croatia) and north-east (Lithuania); there are also cases from Central (Slovenia, Austria) and Western Europe (Scotland). The majority of them focus on the national ritual years that circulate also abroad, in new cultural contexts, and reveal differences between the diasporas and the motherland.

Laurent Sébastien Fournier (France) in his article "Circulation and Differentiation of Scottish Games and Sports" investigates a unique case of selectivity in the status and spread of traditional folk sports. The two major types of the 
Scottish traditional games - the folk-football and the Highland games - exemplify a paradoxical differentiation regarding the mobility of sport festivals. The former remains popular mainly in Scotland, whereas the latter has migrated within the British Commonwealth and almost around the world and is taken as a master sample of Scottishness, in terms of tartans, bagpipes and other national stereotypes. The differentiations between sports in Scotland and abroad, as Fournier argues, show that "the Scottish identity is disconnected from any spatial references in the new context of a global circulation of ritual patterns". Interestingly enough, the exported version of the Highland sports contributes to their development in the home country.

Two of the articles trace the changes in the festive systems of a nation during the last century and up to the present day. An interesting case of the differentiation of the ritual year is given by Ingrid Slavec Gradišnik (Slovenia) in her article "A Festive Bricolage: The Holiday Calendar in Slovenia over the Last Century". During the 19th and 20th centuries this country underwent at least four changes of political regimes and was part of different countries until it gained independence in 1991. Each political formation brought along new languages, new co-members, new values, various attitudes towards the Church and, correspondingly, new holidays to be celebrated. Being an independent state or a dependant one, i.e., a part of a bigger country (like Slovenia in the two Yugoslavias - the royal one and the federative republic), and being a majority or a minority greatly influences the character and the content of the ritual year. As this and some other cases presented in this volume show, the intention to keep the national identity and to oppose the Other is demonstrated through the selection and circulation of certain "own" festivals. Thus the commemorative day of the Slovene poet France Prešeren (February 8) has preserved its value through all the regimes and in the present-day state has obtained the status of the Slovenian Culture Day. At the same time official holidays of the ritual year are often perceived as foreign and thought of as "their" holidays. In socialist Slovenia, this is the case with the Serbian and Croatian Saint Vitus' Day, and Tito's birthday on May 25 celebrated as the Youth Day.

The modern Slovenian ritual calendar, as well as festive systems in other post-socialist countries, is seen by ethnologists as a "bricolage", a mixture, consisting of a combination of old, authentic, and new traditions, including many borrowed and adopted holidays.

Two political rituals in the Slovene diaspora in Austria are described by Jurij Fikfak (Slovenia) in his article "Political Rituals and Discourses: The Case of Carinthia". The author investigates the celebration of a very special event, which marks the historical plebiscite of 1920 for Carinthia to stay "free 
and undivided" in Austria, and deals with the concepts of national mentality. Both ethnically and regionally, this festival has a strong state image, yet is unconnected to other calendrical festivals, which are very popular among Slovenes and Austrians. Still the official celebrations (processions, presentations, concerts, etc.) with the participation of statesmen play an important role in political life; the attendance of statesmen at the festival influences elections and has an impact also on other issues. The second, newer, commemorative ritual Fikfak investigates is a recent acquisition introduced in 2008 - an anti-fascist procession, remembering the martyrs of the concentration camps, mainly from the Slovenian community. The mass media discourse investigated in detail by Fikfak proves to be extremely important for the differentiation and circulation of the festivals, be they political or not.

A few more interesting and important details are added to the topic of the volume through the case analysed by Juraj Belaj, Marijana Belaj, Petra Kelemen, and Filomena Sirovica (Croatia) in their co-authored article "Politicising St. Martin and Constructing Heritage: A Case Study of a Small Town in Croatia". This article deals with an example of how a religious festival, the commemoration of Saint Martin (November 11), after having been ousted from the public festive life of former Yugoslavia for a period of 45 years, eventually turns into a major significant ritual complex. This process of "martinisation" started in the 1990s, in the small town Dugo Selo, not far from the capital Zagreb, where in 1993 this day was declared a municipal holiday, and St. Martin was declared the patron saint of the town. The selection of this day is associated with many factors, for instance, commerce, winemaking, and tourism. ${ }^{5}$ The process of constructing the festival as an old Slovenian one is supported by the new archeological finds in Dugo Selo, which date back to the epoch of the Templars and are interpreted as proof of St. Martin as one of the pro-European symbols in this exact location.

The reconstruction, invention and circulation of a selected holiday in presentday Russia is investigated by Nina Vlaskina (Russia) in her article "The AgeOld Cossack Feast of the Protecting Veil: A Contemporary Interpretation of a Traditional Calendar Date". The author describes the construction process of the ritual year by Don Cossacks, who have historically been engaged in military activity and hunting. Usually a date from the religious or historical calendar is selected and being "privatised" by an ethnic, professional, or religious group, which puts in an enormous amount of work to prove that this is a traditional holiday, associated with this particular group from time immemorial. After perestroika, when the process of the Cossaks' revival started and they re-inforced their identity, they declared the Christian Orthodox feast of the Protecting 
Veil of the Mother of God as "the main Cossack national holiday". The reason for selecting this holiday as their own is associated with the meaning of the feast - the idea of protection and commemoration.

The Lithuanian metamorphosis of the well-known European holiday of Shrovetide (Užgavènès) is investigated by Žylvytis Šaknys (Lithuania) in his article "Užgavėnès: A Rural and Urban, Religious, Socialist, and Lithuanian Festival of Shrovetide". The original agrarian and seasonal meaning of the festival as a "farewell to winter", with ritual food, masking, guising, and merrymaking has been selectively modified with urbanisation, change of ideology and globalisation. In the beginning, under the Soviet occupation, the socialist government marginalised this feast similarly to other religious and folk celebrations. Later on the general meaning was transformed and the festival took the form of fighting against evil, as most of the Soviet holidays had to be flavoured with antagonism. In the 1990s the Shrovetide festival turned into one of the major seasonal celebrations, and as such has been attracting and absorbing many festive components and developing new semantics, with new images, masks, and new games created. As this case makes evident, the return to a pre-Soviet state does not entail a return to authentic ethnographic celebrations. Many Soviet Lithuanian innovations in Shrovetide celebrations have been preserved, and are now combined with new adopted globalised forms of entertaining. Celebrating Shrovetide abroad in the Lithuanian diasporas is strictly connected with Lithuanianness.

In summarising these six cases, it should be mentioned that the selection and circulation are often carried out by the governmental elites and are not felt as "our own" by the population. Folk celebrations, on the other hand, are not welcomed by the state, but they are preserved and survive until the regime changes. The 1990s formally destroyed the socialist camp and brought along drastic changes in the ritual years, usually supported by state decrees giving up the existing festive system. This happened in Slovenia, Russia, and also in other countries. The festivals suppressed during socialism turned into major ones and were chosen to express national identity, both in the homeland and abroad.

With regard to selectivity and circulation, the contemporary ritual years are subject to various modifications. Among these we would like to stress the quantitative growth of the festivals due to people's intention to celebrate more often and follow the examples of mass culture, the development of the commercial and touristic activity, and the openness of the borders. All these processes facilitate the cultural and festive interchange between neighbouring countries and the migration of festivals, as well as enhance Western and 
Eastern influences and globalisation. If we take into account the selection and preservation of the national, local, or regional holidays as essential fragments of heritage, we find unrestricted possibilities for constructing the modern ritual year and the rhythm of celebrating.

\section{NOTES}

1 See the webpage of the Ritual Year Working Group on the SIEF website: http:// www.siefhome.org/wg/ry/index.shtml. Reports on the Ritual Year Working Group conferences have been published in English in journal Folklore: Electronic Journal of Folklore (EJF). For the reports on the 6th, 7th and 8th international conferences see: Sedakova 2010; Sedakova \& Sidneva 2012; Sedakova 2013. The report on the 10th conference is published in the current issue.

2 Concerning the analysis of the increase or decrease of rituals in contemporary Europe, a fine introduction can be found in Jeremy Boissevain's book Revitalizing European Rituals (1992).

3 As concerns the relation between globalisation and fragmentation, see, for instance, how Saskia Sassen connects globalisation with the local places in which the global dimension is discussed and built up (Sassen 2007).

4 In this respect, our aim is to combine the study of rituals and the study of performances. For a general overview, see Bell 1992 for rituals and Schechner 2003 for performances.

5 St. Martin's Day is celebrated in other countries of the region. On November 11, 2012, during the 7th International Conference of the SIEF Ritual Year Working Group in Slovenia, the ritual martinuvane, the tasting of the new wine, was performed in a local restaurant, showing a fine example of the adaptation of a traditional ritual to an international scholarly audience.

\section{REFERENCES}

Bell, Catherine 1992. Ritual Theory, Ritual Practice. New York \& Oxford: Oxford University Press.

Boissevain, Jeremy 1992. Revitalizing European Rituals. London \& New York: Routledge. Sassen, Saskia 2007. A Sociology of Globalization. New York: W.W. Norton \& Company. Schechner, Richard 2003. Performance Theory. London \& New York: Routledge.

Sedakova, Irina 2010. The Inner and the Outer in the Ritual Year: Traditions and Today. Folklore: Electronic Journal of Folklore, No. 46, pp. 198-202. Available at http://www.folklore.ee/folklore/vol46/n01.pdf, last accessed on March 3, 2015.

Sedakova, Irina \& Sidneva, Svetlana 2012. Rituals and Customs as Cultural Heritage through the Eyes of Researchers and Performers. Folklore: Electronic Journal of Folklore, No. 50, pp. 162-167. Available at http://www.folklore.ee/folklore/vol50/ n05.pdf, last accessed on March 3, 2015. 
Sedakova, Irina 2013. Migration in the Context of Rituals and Practices. Folklore: Electronic Journal of Folklore, No. 53, pp. 173-179. Available at http://www.folklore. ee/folklore/vol53/n01.pdf, last accessed on March 3, 2015. 


\title{
CIRCULATION AND DIFFERENTIATION OF SCOTTISH GAMES AND SPORTS
}

\author{
Laurent Sébastien Fournier
}

\begin{abstract}
The circulation and differentiation of the Scottish games and sports through time and space offers a fine example to study the mobility, adaptation and reconstruction of traditional rituals and festivals in general. On the one hand, traditional games such as folk-football or 'handba' remain closely connected with their original spaces and still take place at special times in the traditional Scottish calendar. On the other hand, the athletic sports and competitions known as the Highland Games have followed the Scottish diaspora in the British Commonwealth and have eventually spread all around the world. While the former address only a limited audience in the original communities, the latter have become famous and address a massive audience worldwide. While folk-football and 'handba' have remained strictly local, the Highland Games have become globalised sports. There is a paradox here, because the globalisation of the Highland Games contradicts the primitive image usually associated with the Scottish Highlands. In this article, I present some data collected both in Scotland and in the United States of America in order to show the changes in the ways that the traditional Scottish games and sports are performed in their original context and abroad. I especially try to show how the Scottish identity is disconnected from any spatial references in the new context of a global circulation of ritual patterns.
\end{abstract}

Keywords: diaspora, diffusion, games, migration, Scotland, sports, United States

\section{INTRODUCTION}

In this paper I would like to take the example of games and sports to study the mobility, adaptation and reconstruction of traditional rituals and festivals in general. To this end, I do not focus on contemporary sports, which are part of the modern mass culture and are closely related to globalisation ${ }^{1}$. Instead, I study the case of some traditional games which I first observed in Scotland but which also exist in other countries and which considerably change when circulating and being adapted to new cultural contexts. These games are connected with the ritual year of the Scottish communities worldwide: they are organised once a year in a given place and constitute moments when the Scots abroad experience their 'Scottishness', which I broadly understand here as the fact of loosely claiming Scottish roots and Scottish 'culture', considering that 
in most of the cases the players do not really know much about the language and the history of this nation.

How do national games and sports change when they are exported to a new country or to a new cultural setting? What happens to them, and how does this transfer change the culture they come from? How does this example help to grasp better the general processes of diffusion and globalisation, and how does it help to understand the circulation and differentiation of rituals and festivals in general? In order to answer these questions, I first focus on the notions of diffusion and globalisation and show that they have recently become the core ideas in the study of games and sports. Second, I describe two different types of Scottish games: the Highland Games and the traditional ball games. Third, I compare the different ways in which these two types of games circulate. I eventually come back to the Highland Games example to enlighten the reader about the differences between the ways they are performed inside Scotland and abroad. Such a comparison shows that even 'national' cultures and stereotypes can dramatically change when confronted with globalisation, circulation and diffusion.

\section{DIFFUSION AND GLOBALISATION}

On the example of games and sports I first ask some questions about the processes of circulation and differentiation of rituals and festive events in general, and then proceed to show that the study of games and sports helps to get a better grasp of these general processes. By doing so, I have reassessed some of the theories concerned with the historical diffusion of Western sports, currently being discussed in France and Great Britain. ${ }^{2}$ Until now, some authors have strongly emphasised the relations between the worldwide success of sports and the history of British imperialism (Darbon 2008). According to this theory, the success of the British Empire in the 19th century would have led the colonies to adopt some of the English sports, except when the body culture of the colonised people was too different to accept them. In India, for instance, cricket has become very popular in the last two centuries, but not rugby, because the caste system has made it difficult for the players to have a close physical contact with one another. The traditional Indian body culture therefore prevented rugby from being diffused in the Indian sub-continent, while rugby was very easily spread, for instance, through South Africa and New Zealand.

Other authors have emphasised the influence of Spanish culture in America, showing how the Spanish traditional bullfights had been transformed in Mexico with regard to the Native American mythologies (Saumade 2008). From Mexico, 
this transformed Spanish culture then reached California and New Mexico, eventually fuelling rodeos and different cowboy games in the south of the United States. In a similar way, different researchers have tried to compare the ways that different sports and games have spread around the world. They have come to the conclusion that some sports - like football - have easily reached the shores of other cultures, while some others have never crossed the boundaries of their country of origin or have remained within the limits of some regions. In this respect, globalisation is an uneven process and does not concern all the different sports.

In another perspective, some studies have emphasised the standardisation of sports in the new contemporary mass culture, while some others have insisted on the new hybrid sports that have appeared at the same time. As usual, when dealing with the notions of circulation and globalisation, some scholars have put the emphasis on the homogeneity of different regional or national cultures, while some others have conceptualised modernity as a means of increasing the diversity and complexity of different cultural practices. A whole range of processes can be observed when discussing sports and globalisation. When moving from one place to another, sports can be more or less acculturated in their new contexts, after being appropriated by new players. In this acculturation process, sports can be hybridised or, on the contrary, they can remain the same if cultural imperialism is strong enough to keep them identical to what they were at their starting point. Globalisation can be viewed as a synonym for uniformity and differentiation or syncretism, which implies a careful look at the empirical data to understand how different practices are influenced by the new settings in which they develop after being separated from their original contexts.

Answers to such questions are never simple, and I would suggest that the increasing circulation of cultural motives in our globalised world involves both unification and diversification processes. This is what makes this field of studies simultaneously difficult and fascinating. But as there are no clear-cut answers to these questions, I have relied on some ethnographic data to clarify the situation.

\section{SCOTTISH HIGHLAND GAMES}

The games and sports I first focus on in this article are called 'Scottish' but they are also practised abroad, on a worldwide level, in a good number of countries. I here consider the category of Highland Games, which are the most famous among the Scottish games. These games originally refer to the Scottish Highlands, but they are played in all sorts of landscapes and places. They take place both in the mountains and on flatlands, all around the world and especially in 
Canada and in the United States, where they have been performed as early as from the middle of the 19th century by the descendants of the Scottish diaspora. As I show further on, these games keep more or less the same structure everywhere. One part of them is especially devoted to athletics, which mainly consist in throwing heavy weights, stones, hammers, and eventually, 'tossing the caber', which is often considered as the most spectacular activity in the games, using heavy trunks and throwing them for distance. ${ }^{3}$

These sports, known as 'the heavies' or 'the heavy events', are often connected in the imagery with the times when the clan chiefs had to select the strongest men for the war, or those with professional skills when work needed considerable strength, like, for instance, in woodcutting. The method of 'tossing the caber' is said to be related with the technique of throwing trees to cross rivers and bring them down in the valleys of the Scottish Highlands. Besides these sports, the Highland Games usually feature other disciplines like the tug-of-war, races, or jumping, and also traditional dancing and piping with the emblematic Scottish bagpipe. Around these different competitions, the spectators can also drink, eat, and have fun at the funfair. Throughout years, the Highland Games have become an important touristic attraction in the summer, as they globally represent the Scot-

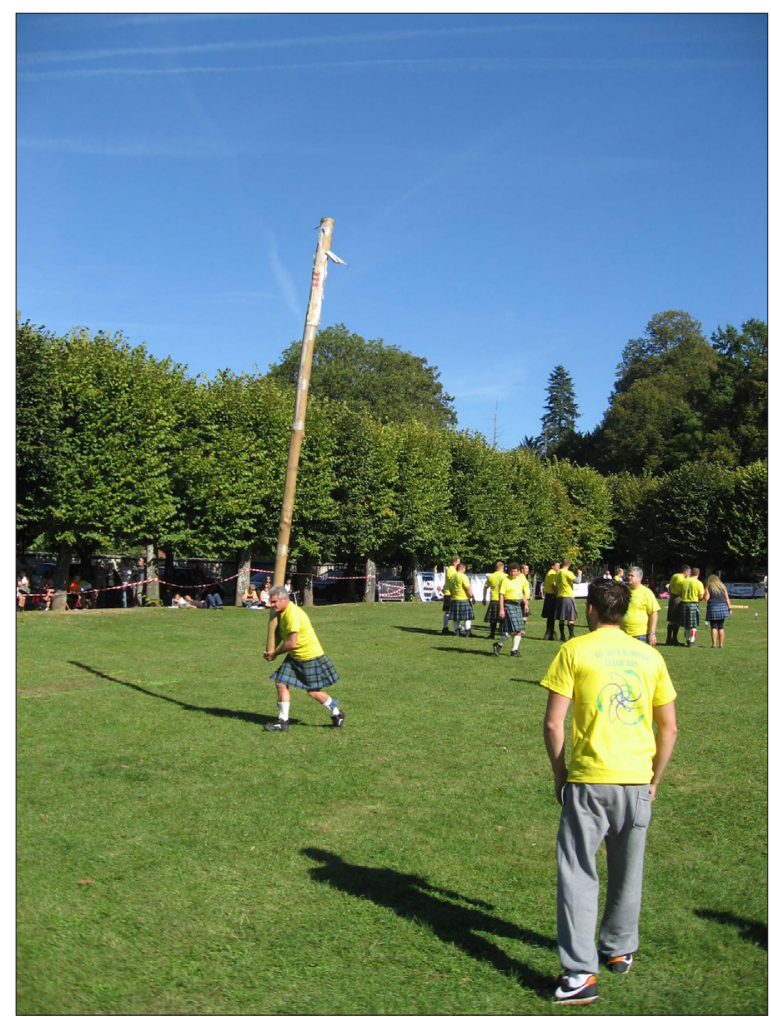
tish identity and values. This is the reason why they have been organised annually in several dozen of Scottish towns since the 19th century.

Figure 1. Caber tossing. Luzarches, France. Photograph by Laurent Sébastien Fournier 2012. 
Interestingly, the model of the Highland Games, although being presented as 'typically Scottish', has not remained in Scotland only. Already in the 19th century, the Highland Games were transferred and adapted to all the places where the Scots had emigrated. Of course, Canada and the United States have been massively concerned (Redmond 1971; 1982), but the games have also become popular in the countries of the British Commonwealth, in Australia and New Zealand, and more recently they have reached other places, such as Japan, France, the Netherlands, Germany, Hungary, the Baltic countries, etc. In all these countries, the Scottish origins of the games are clearly emphasised and athletes circulate around the places where the best stone throwers or specialists in 'caber tossing' in the world can be found. In spite of having a traditional 'Scottish' image, the contemporary Highland Games feature a truly globalised sportive event, involving special championships, prizes, and specialists. Each year, hundreds of thousands of people attend the games, which simultaneously perform different competitions and present a distinctive image of the Scottish identity.

Fieldwork in the different places where the Highland Games are organised shows that they can vary considerably, being rural or urban, bigger or smaller, more or less conservative. However, in all the places where I have attended a number of them - in Scotland, but also in France and in the United States participant observation and interviews show that they all present the same key features: heavy athletics, traditional dances, and bagpipe competitions. Moreover, there are some federations like the Scottish Highland Games Association (SHGA) or the International Highland Games Federation (IHGF), who act as powerful bodies in reinforcing the homogeneity of the games and helping the circulation of unified standards. ${ }^{4}$ Over the years, the Scottish Highland Games have become famous and have plenty of followers. They address a massive audience worldwide and are organised as modern athletic sports, often compared with track and field sports.

\section{SCOTTISH TRADITIONAL BALL GAMES}

It is interesting to compare this highly standardised Highland Games model with other forms of traditional games and sports in Scotland. Scotland has been the cradle of golf, shinty (a team game played with sticks and a ball), and curling. Golf has become a successful sport in the modern times, and some valuable analyses still need to be undertaken to understand the history of the diffusion of this sport. Yet, some traditional ball games also exist in Scotland, and below I would like to concentrate on this example. In the Scottish Borders region in 
the south, but also in the Orkney Islands up north, some villages annually play the games called folk-football or handba. These games are interesting because they are strongly connected with the traditional calendar as well as with their places of origin.

The game of folk-football or 'ba' game', as it is often called, usually takes place once a year in a special place. Nowadays it is played in less than ten places in Scotland but, according to archival records, it used to be played in more places in the past. On a fixed date, which can be Christmas in the Orkney Islands or around Shrovetide in the Borders, the villages are divided into two groups, which contest for one or several leather balls. The two groups are known as 'uppies' and 'downies' because they come from the upper and the lower parts of the villages, respectively. Some officials throw up the balls and the game - or the different sets of the game, according to the places - features a large melee which people often compare with primitive rugby. ${ }^{5}$ The melee is quite spectacular and attracts spectators, including journalists, but the game is played out of season and it is often presented as violent and dangerous, although it does not cause much damage in reality (Fournier 2013). However, the bad reputation of the game and its supposed violence lead the players to advertise it as little as possible, and therefore the game usually remains mainly local.

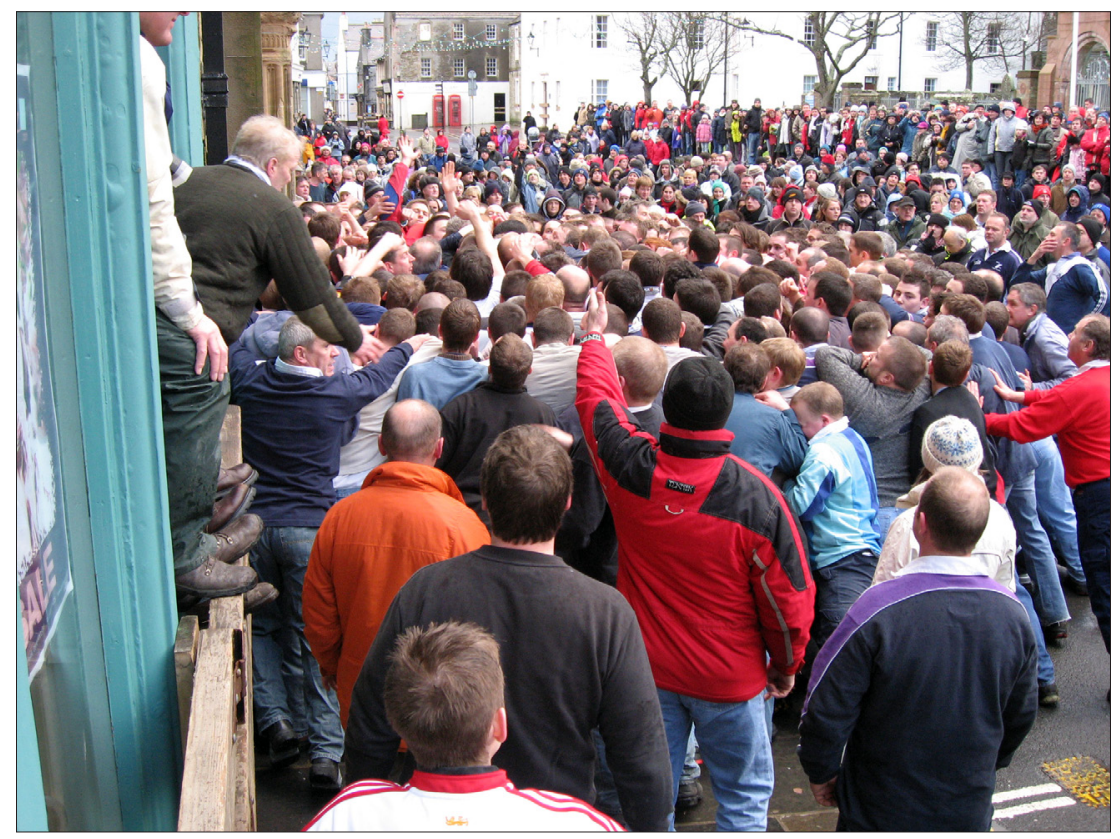

Figure 2. Folk-football. Kirkwall, Scotland. Photograph by Laurent Sébastien Fournier 2007. 


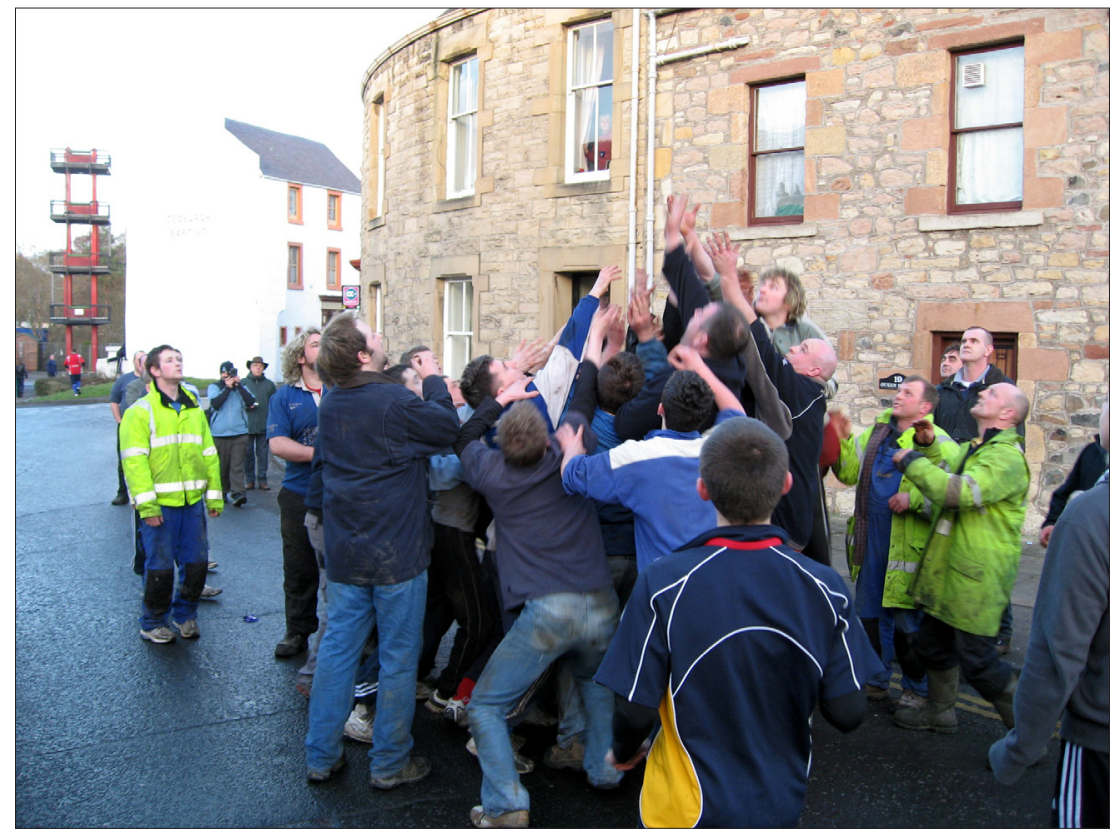

Figure 3. Handba. Jedburgh, Scotland. Photograph by Laurent Sébastien Fournier 2008.

This example is interesting as regards the question of circulation, because it has not been adapted abroad in spite of its important role in the shaping of the traditional ritual calendar of Scotland. Many people know about the game, especially in its Orcadian version, and everybody regards it as a typical local custom. However, unlike the Highland Games model, folk-football has not been exported as such, except if we consider soccer and rugby as the modern evolutions of the game. Interviews after folk-football matches showed that the locals who had emigrated sometimes came back for the game, especially in the Orkney Islands, where the game is played at Christmas, but nobody has tried to play the game abroad, except as a re-enactment in an Italian festival of traditional games in Verona, two or three years ago.

\section{DIFFERENT GAMES, DIFFERENT CIRCULATIONS}

I do not insist here on the cultural importance of the game of folk-football. In a previous article, I already suggested that in spite of its apparent roughness, the game structures are extremely complex (Fournier 2013). In her works on seasonal contests, Emily Lyle (1990) has brought evidence that this game could 
be connected with the structure of the ritual year in a larger Indo-European context.

Rather, I would like to question the contrast between the games that are easily exported, like the Scottish Highland Games, and the ones that are not. The Scottish material I have presented here shows, on the one hand, a set of games which have turned global and have followed the Scottish diaspora abroad, and, on the other hand, another set of games that have remained strictly local and only address a few thousand people in the country. At the same time, only the Highland Games explicitly claim their 'Scottishness', whereas the folk-football is said to be 'local' and 'traditional', but not especially 'Scottish'. Only the Highland Games refer to tartans and bagpipes and have a clear connection with the Scottish national stereotypes. They are also the only ones that have been commoditised for the needs of tourism industry. Some people certainly claim that folk-football is a national game because Sir Walter Scott played a role in advocating it: according to historian John Burnett (2000), he organised a match in Carterhaugh in 1815. In these games, however, the players very rarely refer to Scotland as a whole. They are much more concerned with the identity of a local town, through the opposition between the 'uppies' and 'downies', for instance, than with any claim of national identity.

This comparison eventually brings us to a paradox. The globalisation of the Highland Games contradicts the primitive image usually associated with the Scottish Highlands, and at the same time the Highland Games have become famous among strangers, for whom they represent a typical image of Scotland. It is interesting to observe that the Highland Games have been selected by strangers, as well as by the Scots abroad, as the best means of representing Scotland. In this context, there is a disconnection between the image of Scotland abroad and what is really going on in Scotland today, because abroad the image of Scotland is still orientated by the primitive Highlands, while the towns and the low country are much more valuated inside contemporary Scotland.

As it often happens in diffusion processes, the older cultural traits remain the most important outside while inside the self-image of the culture has already dramatically changed. The world still follows the 19th-century romantic images of the Scottish Highlands through the Highland Games, while new 'modern' priorities have appeared in contemporary Scotland. At the time when Scotland is seeking for national independence, it is not a real surprise to see that tartans and bagpipes are often considered old-fashioned and even ridiculous by the new Scottish creative classes (Nairn 2003 [1977]). However, these emblems are still massively used to represent Scotland in the United States or in the former British colonies. Interestingly, the new places that are willing to be identified with Scotland, in Europe or elsewhere, also use the old models instead of looking 
closer at the contemporary Scottish culture. In a way, the accepted romantic image of Scotland, as it was developed in the 19th century, is like a ghost still haunting contemporary Scotland with outdated images and stereotypes.

\section{COMPARING HIGHLAND GAMES IN SCOTLAND AND ABROAD}

It is interesting to compare in more detail the Highland Games of Scotland and the Highland Games abroad, in order to grasp their differences and to ascertain what elements have been selected and why. Attending the Highland Games in Pleasanton, California, and in Grandfather Mountain, North Carolina, is extremely instructive in this respect. ${ }^{6}$ These two Highland Games are clearly the most populous in the world, with tens of thousands of visitors every year. In spite of their obvious differences - the former occur in an urban area on the western coast and are more than a hundred years old, while the latter take place in the very heart of the Appalachians in the southeast of the country and originate in the $1950 \mathrm{~s}$ - these two events have much in common if you compare them with their Scottish counterparts.

Indeed, the organisers of the American Highland Games are usually highly respectable people, but they are rarely part of the national intelligentsia, as they can be in Scotland, for instance, in the Braemar Games where the royals themselves ritually open the ceremony. Of course, a great number of WASP representatives can be found in the American Highland Games, and the fact of claiming Scottishness in America is clearly connected with the older layers of European settlers and with a special form of establishment. Most of the Scots arrived in North Carolina in the 18th century, if not before, and some of the participants in today's games claim an uninterrupted ancestral line in the region since these times. But at the same time, in the United States, even the most powerful sponsors of the Scottish games do not have any real political or symbolic influence in the country as a whole. Scottish culture only represents one of the many minorities which form the American 'melting pot'. Even if the United States have officially acknowledged the role of Scottish culture in the building up of the country, and even if April 6th was proclaimed 'Tartan Day' by the Senate in 1998, most of the public decisions regarding the valorisation of Scottish culture in America remain purely symbolical. They address the nostalgia of a few veterans and military personnel who consider Scotland as a model of strength, courage, and military virtue, but the dominant American decision-makers and stakeholders may never have heard about Scottish culture in America. In general, the American Highland Games are considered as family events, in which folklore and entertainment take a major place. Even if 
the American Highland Games actually gather more people than the Scottish ones, it is important to remember that they only represent a minority among many others in the United States.

It is, however, interesting to examine the differences in the programmes and in the styles of different Highland Games, both in Scotland and in the United States. I have already pointed to the similarities among all the different games. The Highland Games usually feature the heavies, the tartan and bagpipe folklore, as well as the fair. But under these apparent similarities, things can happen in very different ways. First, the American Highland Games feature a few sequences that do not exist in Scotland, for example, the Kirking of the Tartans, a moment when the flags of the Scottish families are blessed by a priest before the United States anthem is played, which appears to be a purely invented tradition of the American Highland Games. ${ }^{7}$ This is also the case with the Drum Major competitions which are gaining popularity in America, especially on the western coast, but which do not really exist in Scotland.

Yet, the differences are not limited to these particular sequences. Staying outdoors in a camping and talking to people at the Grandfather Mountain Highland Games shows how the American Scots manage to hybridise and combine the Scottish culture

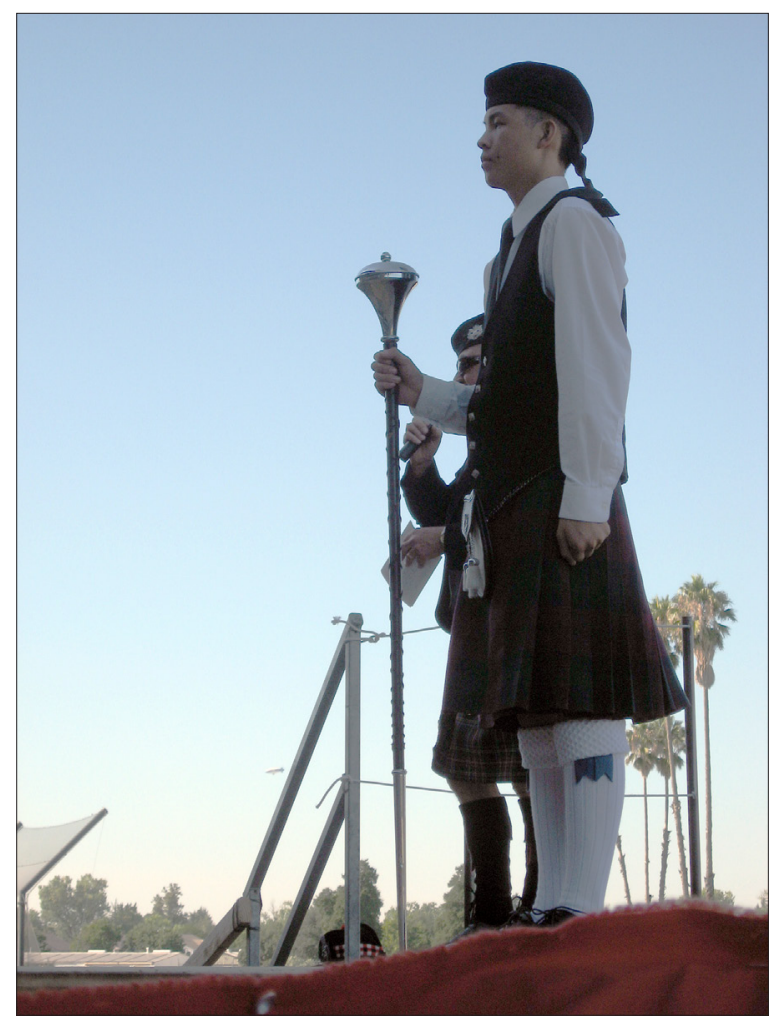
they are claiming and the Southerners' culture they are more familiar with. Indeed, most of the people here come in big RVs and look considerably more American than Scottish. Even if they wear kilts, they bring with

Figure 4. Drum major competition. Pleasanton, California. Photograph by Laurent Sébastien Fournier 2012. 
them plenty of clues concerning their American way of life. In interviews, they easily confess that they are not really Scots: some of the people I met in the American Highland Games told me they loved 'playing Scots' and liked 'everything Celtic', but most of them did not really claim any 'Scottishness'. Some of them have been involved in living history events and re-enactments before attending Scottish gatherings. When they celebrate, the 'Scottish' music they listen to often relies on heavy American references, either in the country or blues style. The American Scots are also much more preoccupied with their DNA than the Scottish Scots are. Several companies come to the games to propose DNA tests in order to trace back Scottish ancestry and reinforce the clan system which has developed in the United States in recent years. ${ }^{8}$ Last but not least, most of the campers have never been to Scotland, and the centre they take their Scottish references from is often Newfoundland, Canada, where the Highland Games existed already as early as in the middle of the 19th century.

\section{DISCONNECTED CULTURES?}

On the example of the American Highland Games, it is interesting to observe how, in the new context of a global circulation of ritual patterns and ideas, Scottish national identity manages to detach itself from its homeland and gets disconnected from any spatial references. How does this disconnection occur and how does it work?

According to the time scale that we use to analyse the circulation and differentiation of the Scottish Highland Games, we can reach different results. Looking at the process throughout history brings awareness of the sad period of the Clearances, when the Scots were forced to emigrate in the 18th century (Prebble 1966). A large number of Highlanders were then replaced by sheep on the lands of the powerful lairds. Boat registers show the importance of Scottish emigration to the United States in this period, after the disaster of the Jacobite rebellion in 1745 . It is not surprising that a number of 'Scottish societies' were founded outside Scotland by the Scots who were trying to help each other in the new hostile world. The first Scottish society was actually founded in London in the $1780 \mathrm{~s}$, but a number of similar organisations appeared in the biggest American towns in the 19th century. Some Highland Games and gatherings were already organised during this period in the United States, as historians have shown (Redmond 1971; 1982), and in some cases they have survived until today, which enables to trace their history back to the moment when they first emerged. 
The historical perspective might, however, be a tricky one when considering the gaps and changes in the American Highland Games through time. Indeed, it would be a mistake to consider the history of these games as being only linear. Most of the games that were organised in the 19th century disappeared at the beginning of the 20th century, before World War I. It is only later that some of them have been revived. According to some specialists, the geography of the games in America has dramatically changed in the past century. While the 19th century games were concentrated in Canada and in the north, many games appeared in the south of the country in the second half of the 20th century (Ray 2001). In these cases, there is no continuity at all with the historical arrival of the Scots in the United States. For most of the participants, memories of the games cover only a few years back. The ethnographic perspective is more productive here than the historical one, allowing to explore the ways the participants identify with Scotland independently from any genuine Scottish ancestry. Most of the people here invent new relations with Scotland and develop a totally free relationship with this imaginary 'motherland'.

In this context, the relations between Scotland and the United States regarding the Highland Games are very complex ones. Interestingly, these relations have evolved in both directions. Historically it is obvious that the American games were strongly influenced by the Scottish ones, as the American Scottish societies were still connected with Scotland and most of their members were born in Scotland. At one point, however, things changed. Professional sports replaced the traditional Highland Games in which amateurs predominated, and the Scottish gatherings progressively faded out. But after World War II the Highland Games were launched on a new basis. American athletes, dancers and pipers became more and more professional and started to attend the Highland Games in Scotland. A few years later they managed to win competitions and travelled more and more to different Scottish games around the world. In Scotland, on the contrary, plenty of participants were quite reluctant about the idea of going abroad and mainly remained amateurs. Most of the Scottish participants still think that the proper place for the Highland Games is Scotland, and only some of them are interested in international competitions. Today, the Scottish Highland Games Association (SHGA) runs the games inside Scotland, while the International Highland Games Federation (IHGF) promotes the games abroad. According to interviews, there are fewer and fewer Scots in the circuit, and more and more international professionals coming from America but also from different European countries. These people certainly remain very interested in Scottish culture and the moral values that Scotland is supposed to carry with the games. They are also very good athletes; they train hard and set records. In this new context, it is interesting to note that 'Scottishness' in the Scottish games and sports is no more a Scottish privilege. The internationalisation 
of the Highland Games has disconnected the Scottish culture from Scotland: international athletes proudly compete in the games, showing how a national culture can survive and develop even if being cut off from its geographical roots.

\section{CONCLUSION}

In comparison with the aforementioned, it is interesting to note that the 'remains' of traditional games still practised in Scotland, like folk-football, do not really claim any connection with 'Scottishness' or any national reference. Still practised at a local level, they have not been exported at all. Due to this, they do not need to seek for any differentiation. They just continue in a customary way, far from the modern arguments between amateurs and professionals, or between Scottish and alien versions of the games. If we consider both these examples, we eventually learn that an outside point of view is always needed to become conscious of one's identity. In the folk-football example, nobody threatens the practice of the local game by imitating it outside. The only threats come from the media and the insurance business, who consider the game as violent and risky. The Highland Games example is totally different. Here, national stereotypes are deeply challenged by their re-enactment abroad. The success of the games abroad leads to dramatic evolutions inside Scotland as well, because the stereotypes now represent much more than merely Scotland. Circulation has led to the definition of a double Scotland: a real one and an imaginary one, whereas the latter can be more competitive and more powerful than the former. This is why the idea of circulation is so important in understanding identity matters.

\section{NOTES}

1 When speaking about the globalisation of sport cultures, I use the definitions discussed and the different case studies published in France, in a recent issue of the Journal des Anthropologues (Fournier \& Raveneau 2010).

${ }^{2}$ On the diffusion of sports, see the recent thematic issue of the journal Ethnologie française (Darbon 2011).

3 See, for instance: http://www.youtube.com/watch?v=ujpfCRpqkFs, last accessed on December 10, 2014.

4 Compare the websites http://www.shga.co.uk and http://www.worldheavyevents.com (both last accessed on December 11, 2014) to find out more about the different ways the Highland Games can be advertised.

5 Compare the videos of the Kirkwall game in 1939 (http://www.youtube.com/ watch?v=CDmZR11B8BQ) and in 2011 (http://www.youtube.com/watch?v=eaBi6VCGrpw) (both last accessed on December 11, 2014) to have an idea. 
6 The fieldwork was conducted in California in August 2012, and in North Carolina in July 2013, thanks to the French CNRS programme "Diffusion internationale, revitalisations et transformations sociales des jeux athlétiques traditionnels: ethnographie et comparaison des modes de pratique en Ecosse et aux Etats-Unis" (IDEMEC, UMR 7307 CNRS et Aix-Marseille Université). See also the websites of the two events: http://www.thescottishgames.com and http://www.gmhg.org (both last accessed on December 12, 2014).

7 See Hobsbawm and Ranger (1983) on the invention of the tradition. Hugh TrevorRoper's contribution to this reflection is especially relevant because it shows how the tartans were already an invented tradition in the 19th century (Trevor-Roper 2009).

8 The Council of Scottish Clans and Associations (COSCA) was founded in the United States in 1974. See: http://www.cosca.net, last accessed on February 11, 2015.

\section{REFERENCES}

Burnett, John 2000. Riot, Revelry, and Rout: Sport in Lowland Scotland Before 1860. East Linton: Tuckwell Press.

Darbon, Sébastien 2008. Diffusion des sports et impérialisme anglo-saxon. Paris: Maison des Sciences de l'Homme.

Darbon, Sébastien 2011. Introduction. La diffusion des sports: Confrontations disciplinaires et enjeux méthodologiques. Ethnologie française, Vol. 41, No. 4, pp. 581592. http://dx.doi.org/10.3917/ethn.114.0581.

Fournier, Laurent Sébastien 2013. Violence and Roughness in Traditional Games and Sports: The Case of Folk Football (England and Scotland). Folklore: Electronic Journal of Folklore, Vol. 54, pp. 39-50. http://dx.doi.org/10.7592/FEJF2013.54. fournier.

Fournier, Laurent Sébastien \& Raveneau, Gilles 2010. Anthropologie de la globalisation et cultures sportives. Journal des Anthropologues, Nos. 120-121, pp. 39-63.

Hobsbawm, Eric \& Ranger, Terence (eds.) 1983. The Invention of Traditions. Cambridge: Cambridge University Press.

Lyle, Emily 1990. Winning and Losing in Seasonal Contests. Cosmos, No. 6, pp. 161-171.

Nairn, Tom 2003 [1977]. The Break-Up of Britain: Crisis and Neo-Nationalism. Altona: Common Ground Publishing.

Prebble, John 1966. The Highland Clearances. Swindon: The History Book Club.

Ray, Celeste 2001. Highland Heritage: Scottish Americans in the American South. Charlotte: The University of North Carolina Press.

Redmond, Gerald 1971. The Caledonian Games in Nineteenth-Century America. Madison, NJ: Fairleigh Dickinson University Press.

Redmond, Gerald 1982. The Sporting Scots of Nineteenth-Century Canada. Madison, NJ: Fairleigh Dickinson University Press.

Saumade, Frédéric 2008. Maçatl : les transformations mexicaines des jeux taurins. Bordeaux: Presses Universitaires de Bordeaux.

Trevor-Roper, Hugh 2009. The Invention of Scotland: Myth and History. New Haven \& London: Yale University Press. 


\title{
A FESTIVE BRICOLAGE: THE HOLIDAY CALENDAR IN SLOVENIA OVER THE LAST CENTURY ${ }^{1}$
}

\author{
Ingrid Slavec Gradišnik
}

\begin{abstract}
Over the last century, and especially after the Second World War, the festive landscape in Slovenia changed radically due to political upheavals and restructuring of the economy and society, and in recent decades due to increasing global integration. This article shows how changes in the public calendar before and after the socialist period are manifest in holidays, reflecting changes under four political systems. These changes have affected not only the official holiday calendar, which usually marks the events that the national community identifies itself with. The post-socialist decades have featured a festive bricolage of reinstituted religious holidays, new state holidays, popular cultural celebrations, revived folk or traditional holidays, and traces of socialist holidays.
\end{abstract}

Keywords: calendar, holidays and politics, post-socialism, Slovenia, socialism, Yugoslavia

\section{HOLIDAYS AND CELEBRATIONS}

The meaning and relevance of holidays for individuals, groups, and communities is multilayered. The most emphasised and outstanding function of holiday and ritual efficacy ${ }^{2}$ is social and symbolic cohesion that crisscrosses religious, political, territorial, generational, self-delimiting, and other dimensions of social life.

Social cohesion is the outcome of the transformation of chaos into order, if one agrees that social life proceeds somewhere between the imaginary extremes of absolute order and absolute chaotic conflict and anarchic improvisation. There is an endless tension between the two, and also a remarkable synchrony. This idea is implicit in Victor Turner's phrase "structure and anti-structure". He sees the two as existing in a perpetual dialectic relationship over time (Turner 1969: 112, 203). As Moore and Myerhoff have argued, "with such a view of culture and social life in mind, collective ritual can be seen as an especially dramatic attempt to bring some particular part of life firmly and definitely into orderly control. It belongs to the structuring side of the cultural/historical process" (Moore \& Myerhoff 1977: 3). 
Imposing cohesion simultaneously has its converse side because festivities and their celebrations are not only polysemous phenomena, but also heteroglossic and contested.

Personal celebrations as milestones in one's life mark relevant passages and events in individual trajectories, whereas the trajectories of societies are referred to in official national calendars that redirect attention from individuals' everyday lives to collective issues. Calendars institute and control religious and economic life, and they codify the passages and ruptures of larger groups and communities by inscribing crucial events and historical figures in calendars. The long history of calendars voices not only concerns, but also the interest, will, and power to regulate society's life: they impose regulations of when and how people should work, when they can rest, whom they can worship, or what they can celebrate (Jezernik 2013a; cf. Makarovič 1995).

Calendars are subject to a selection process by which the authorities or dominant ideology determines what is important in society and what is not, and which personalities, events, and actions are constitutive for various groups and communities (e.g. nation, country, and religious congregation). An important effect of calendars is defining and controlling the rhythms of time (RihtmanAuguštin 2001) and the momentary stopping of time through remembering 'holy' days (Velikonja 2013). By so doing, they more or less explicitly appropriate power over the past, present, and future, and over collective memory and oblivion.

In this regard, calendars have a regulatory and integrative, and simultaneously also a stratifying or segregating function. The integrative function is oriented toward the collective horizon of the community and toward connecting people by emphasising their similarity, shared heritage, and especially values through holiday rituals ${ }^{3}$, and striving to reduce differences between people so that they think, feel, and act as in tune as possible, and to strengthen social and ethical norms. The stratifying or segregating effect is the opposite: social cohesion, which ought to be created and strengthened by the calendrical and ritual ordering of time, is never absolute. During holidays and holiday practices certain individuals and groups are excluded or marginalised because they cannot or do not wish to identify with them. In practice, it means that holidays carry a built-in conflict.

Both functions of the calendar reflect power relationships, and in this sense the calendar is an instrument of power that governs people's lives in various ways in a top-down manner. On the other hand, calendrical signposts established through red-letter days (i.e., days off), and usually also more or less entrenched scenarios of celebration, largely leave people at least partially spend them in their 'own way', as, for instance, Sundays. In this respect, the 
enactments of calendars reflect a constant negotiation between hegemonic acts of instituting calendar holidays as special days, and a multitude of alternative ways of how people/citizens celebrate them or not. Holidays are or create venues for socialising, enabling individuals and groups in these venues to (not) identify with others in order to maintain old bonds and create new ones during them. In Geertz's terms, their ritual forms and contents are a metasocial commentary.

From this perspective, a festive calendar is some sort of social seismograph. When I refer to the calendar as a social seismograph, I am thinking of patterns of distribution of holidays or festive days through the calendar year, of the phenomena that festive days stand for (i.e., as signifiers), and of social agents. Speaking of social agents means bringing into discussion the articulation of power that takes different forms and reaches different levels of society. By social agents, I refer to those that use specific political, ideological, or ethical intentions to institute red-letter days and canonise the 'right' version of communities' pasts, presents, and futures, and those that are meant to celebrate them, irrespective of whether they do so or not.

Here it is important that (calendar) holidays and celebrations not only represent, symbolise, or express the structure of a social landscape, but they also help create it; they are not only a representation; they are also a form of practice, as emphasised, for example, by Pierre Bourdieu (1977, 1990) and Catherine Bell $(1992,1997)$. An important characteristic of these practices is that they are embodied (Bell 2008), which is very much in the foreground in holiday rituals: namely, the performing of rituals is most closely connected with sensory experience; that is, embodied cognition and embodied practice (Sax \& Quack \& Weinhold 2010: 8). This fact is central in dealing with social actors because it is one of the mechanisms or parts of the equipment that explains how a feeling of affiliation is socialised, how a sense of belonging is expressed, and, last but not least, why traditions are tenacious.

Another important characteristic of the calendar is that it amalgamates two basic conceptions of time: the linear and the cyclical one. Very generally, the linear conception implies dynamics, innovations, and change, whereas the cyclical conception, grounded in repetition, points to various traditions.

With their regular annual repetition, calendar and festive calendar events are so much anticipated that they are submerged into everyday life. Still, such cultural constructs often directly determine our lives and form our worldviews. We accept calendar and festive calendar rhythms as something understandable in themselves, and only notice them when something about or within them changes. (Rihtman-Auguštin 2001: 1) 
The next characteristic that significantly defines holidays both from the historical perspective and in images of the variegated contemporary holiday landscape is that they preserve a paradigmatic (universal) and syntagmatic (particular) nature:

[---] holidays are both paradigmatic and syntagmatic: that is, they are generally known and widely celebrated, but always under particular circumstances, at particular places, with a particular group. In one sense, all celebrations of a holiday are the "same," because the occasion and frequently the symbolic components are socially and historically derived. In another way, no two celebrations are ever the same. Holidays are always manifested as particular instances, particular events. (Santino 1996: xvi-xvii)

The fused perspective of a paradigmatic chain and syntagmatic polyphony also offers a tool for understanding the research focuses when dealing with holidays and holiday or ritual events; it emphasises the character of long-lasting phenomena and the simultaneous cultural transformations, and indirectly also facilitates the revelation of both transnational and inter-local flows of exchange and intertwining among central and marginal cultures, between global and local variants of individual holidays, and especially holiday practices, in particular also the relationship between politics and holidays. ${ }^{4}$

Political regimes are keen to mark their ideologies into calendars by eliminating older incongruous holidays and introducing more 'proper' ones. Sometimes the changes may be radical, as is demonstrated by the French Republican calendar. This has not been the case with the Slovenian festive calendar. However, changes of political systems have introduced new holidays that reinforce new political ideas and goals, institute new values, and, especially, evaluate the past differently.

The history of the Slovenian festive calendar over the last century falls into four state formations and the respective political regimes: until 1918 the Slovenian territory was part of the Habsburg or Austro-Hungarian monarchy, from 1918 to 1941 it was part of royal Yugoslavia ${ }^{5}$, and from 1945 to 1991 part of socialist Yugoslavia; since 1991 Slovenia has been an independent country (and since 2004 also a member of the European Union). 


\section{SLOVENIA IN THE HABSBURG MONARCHY}

In pre-modern times, the social rhythm of work, rest, religious contemplation, and rituals was dictated by religious holy days of obligation and Sundays. The religious and agrarian calendars matched. In the rural environment, even in the 19th century, the general awareness of the calendar or experience of time was very rudimentary, much like in the Late Middle Ages: the calendar of work and holidays was socialised mainly orally and through church, by repeating the traditional holiday practices in the annual cycle.

Such is also the image provided by traditional ethnographic research on folk culture. With regard to the 19th century, ethnographic writing does not specify when the first national holiday or other memorial days were mentioned. It is true, however, that Slovenian society at the time was not very differentiated; secular holidays to mark important historical events and personalities were predominantly held in urban areas.

The first real national holiday in Slovenia was the birthday of Emperor Franz Joseph I, which was first celebrated in Ljubljana on August 18, 1849. It was presented in a markedly political manner: reflecting the unity of all the peoples within the Habsburg monarchy and their loyalty to their ruler. The great celebration took place in Ljubljana, the centre of all Slovenians, and for this occasion the city was decorated accordingly: houses were adorned, thousands of lights were burning, and a colourful Austrian eagle was sparkling from the castle, bearing the inscription Vivat! This was also the only national holiday until the Austro-Hungarian monarchy dissolved (Jezernik 2013a). However, until 1911, there were sixteen holy days of obligation aside from Sundays. Also important were saints' days conceived as turning points from farm work and chores, but their number had been shrinking noticeably in the spirit of the motto 'time is money', typical of the time of industrialisation (Makarovič 1995). ${ }^{6}$ Gradual secularisation of society was also hinted at through celebrations organised by various associations and celebrations of anniversaries with regard to worthy men, especially men of cultural importance, such as the poet France Prešeren. Today the day of his death (February 8, 1849) is a Slovenian cultural holiday.

Alongside traditional folk holidays, the celebration of Labour Day on May 1 acquired special prominence towards the end of the 19th century, and it became traditional in urban and workers' areas. The first celebrations accompanied by social democratic demands were held in major cities as early as 1890. Typical celebratory iconography was present: a reveille by a workers' brass band, a parade of festive workers decked out in their best, speeches at gatherings, and 
a feast with music, dance, food, and drinks. Elements of folk feasts made their way into the celebration: setting up maypoles, lighting bonfires, and decorating with greenery. It should be emphasised that the holiday was not exploited to stress ethnic or national conflicts (Slovenians vs. Germans or Italians) and confessional differences; the Catholics added their religious ceremonies to the celebrations of the day. The holiday was given publicity in newspapers of the time, although the Slovenian social democrats were not a strong political grouping. In the final years of the First World War, the celebrations acquired a marked peace and antiwar note (Rozman 1999).

\section{BECOMING YUGOSLAVS}

In the new state of three South Slavic nations (Serbs, Croats, and Slovenians), three national holidays were established: June 28 (Saint Vitus' Day (Srb. Vidovdan), a memorial day of those who have died for faith and fatherland), July 12 (Peter's Day, the birthday of King Peter I), and December 1, the day of the union of the 'three-named nation'. The first one was meant to ensure the continuity of celebrating the emperor's birthday, whereas the other two were new. To Slovenians, these were holidays established authoritatively by the hegemonic nation, the Serbs, and their reception was therefore quite dissonant. The disputable nature of these holidays is best demonstrated in Saint Vitus' Day, which was a Serbian religious (Orthodox) and national holiday to mark the resistance to the Ottomans. It was particularly stressed in 1889, when the Serbs observed the 500th anniversary of the Battle of Kosovo, but it only became established as a red-letter day in the calendar of the Kingdom of Serbia in 1914. Among the South Slavs, it began to be popularised during the First World War, when, in 1916, the Yugoslav committee in London pronounced Saint Vitus' Day the national holiday of Serbs, Croats, and Slovenians finally being liberated from the Ottomans, at the same time hoping for prompt liberation from Austro-Hungarian rule, for which they were seeking international support. Special emphasis was placed on the historical and mythicised role of the Serbs, which in this case particularly referred to their role in protecting Christian Europe from the Ottomans (Jezernik 2013b). However, in the new country the Croats and Slovenians, who had already formed their national and confessional (Catholic) identity earlier, opposed Serbian heroism, also by resisting this holiday. Rather than integrating them at a symbolic level, the holiday disintegrated the three nations, undermining them from within (based on their liberal or conservative standpoint), while also excluding minorities, 
particularly the Muslims, all this despite having an additional emphasis after 1919 - to commemorate the soldiers fallen in the First World War. In Ljubljana, Orthodox worshippers also celebrated Saint Sava's Day on January 27. Religious holidays aside, national holidays in the three-nation state were an important instrument of Yugoslavisation that was orchestrated by the Serbian hegemony. Celebrations were held by decorating the towns, military band concerts, dances for officers, choral concerts, town council sessions, and also religious rites. This period also saw a growing number of celebrations of memorial days of worthy men, political anniversaries, and anniversaries of associations, organisations, and institutions (Melik 1999).

What was left from the times of the Austro-Hungarian Monarchy was religious and folk celebrations.

In the first Yugoslavia, the authorities were not in favour of celebrating May 1, which they saw as a manifestation of socialism: processions were forbidden, but people in major workers' towns still celebrated it by attending gatherings (Simonič 2000).

\section{CELEBRATIONS IN EXTREME WAR CONDITIONS}

During the Second World War, circumstances were specific: the Slovenian territory was divided by Italian, German, and Hungarian annexation, and the Axis forces imposed their own national holidays. An alternative to these were Partisan holidays; initially they bolstered the self-esteem of people at war and aimed to integrate the Yugoslav peoples, but towards the end of the war they also reinforced more specific class-related and ideological ends (Repe 1999). The most accentuated and widespread were celebrations of Prešeren's death and Labour Day on May 1. A holiday was formed based on an event during the war, celebrating the establishment of the Anti-Imperialist Front (later renamed the Liberation Front) on April 26, 1941, and it still continues to divide the Slovenian political scene, the media, and the public. However, the Partisans also celebrated Christmas, New Year, and other religious holidays. After 1943, the cult of Tito began to take root, and after the war Tito became a real symbol of Yugoslavia, and his fictitious ${ }^{7}$ birthday became Youth Day (May 25).

From the perspective of what had to be and what actually was celebrated, the years of the Second World War seem to be the beginning of establishing the socialist calendar, which at the time was not yet simply stripped of traditional, particularly religious, holidays. 


\section{THE SOCIALIST FESTIVE LANDSCAPE}

This process was realised gradually, beginning right after the Second World War with two main directions: by introducing new holidays and eliminating the old ones, particularly religious holidays, but also by blurring or displacing the content of some previously widespread holidays, both religious and secular. Following the separation of church and state, former religious holidays became working days.
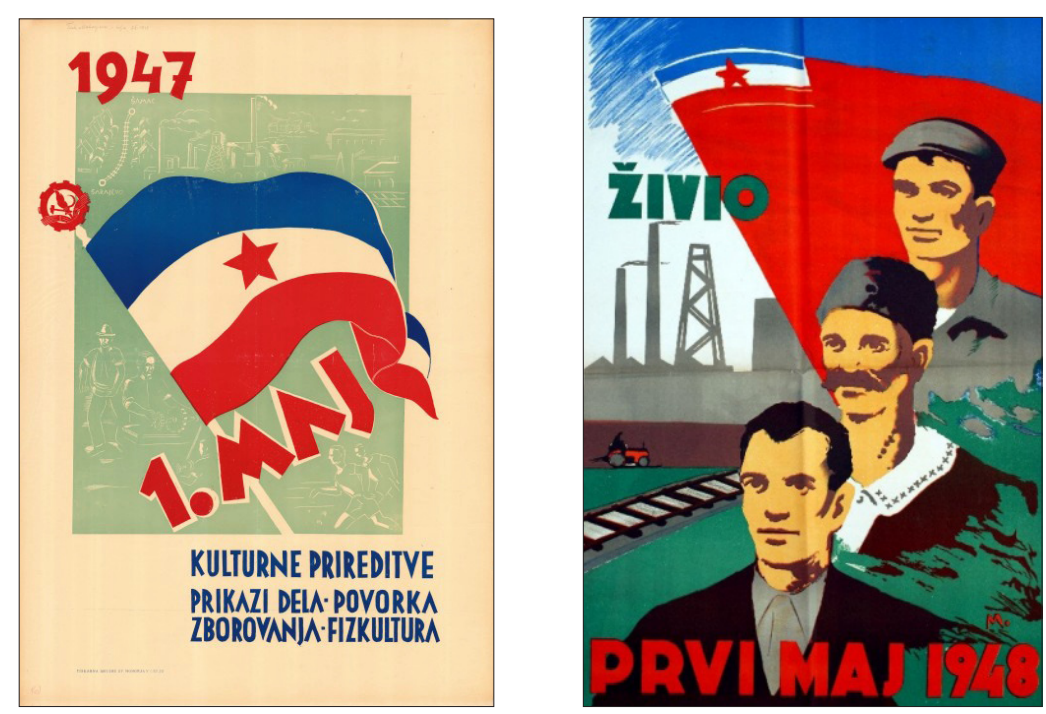

Figure 1. May 1 posters from 1947 (http:/ / www.dlib.si/details/URN:NBN:SI:IMGDI65QBP8) and 1948 ( http: / / www.bhbrands.ba / shop /product/293/plakat-1.maj-1948).

The function of new holidays was a thoroughly planned celebration and strengthening of the political and ideological system, the herald of which was the Communist Party. During the war, the party worked towards two objectives: national liberation and seizing power after the war. In the first years, it followed the Soviet example closely, but liberated itself from its influence in 1948, following the conflict between Tito and Stalin, thus winning the favour of Western countries. Afterwards, its position was specific, lying outside the Soviet Bloc, which is why the socialism of Yugoslavia is considered 'socialism with a human face'; even so, it permeated all the pores of the social life like a pyramid scheme. ${ }^{8}$ 

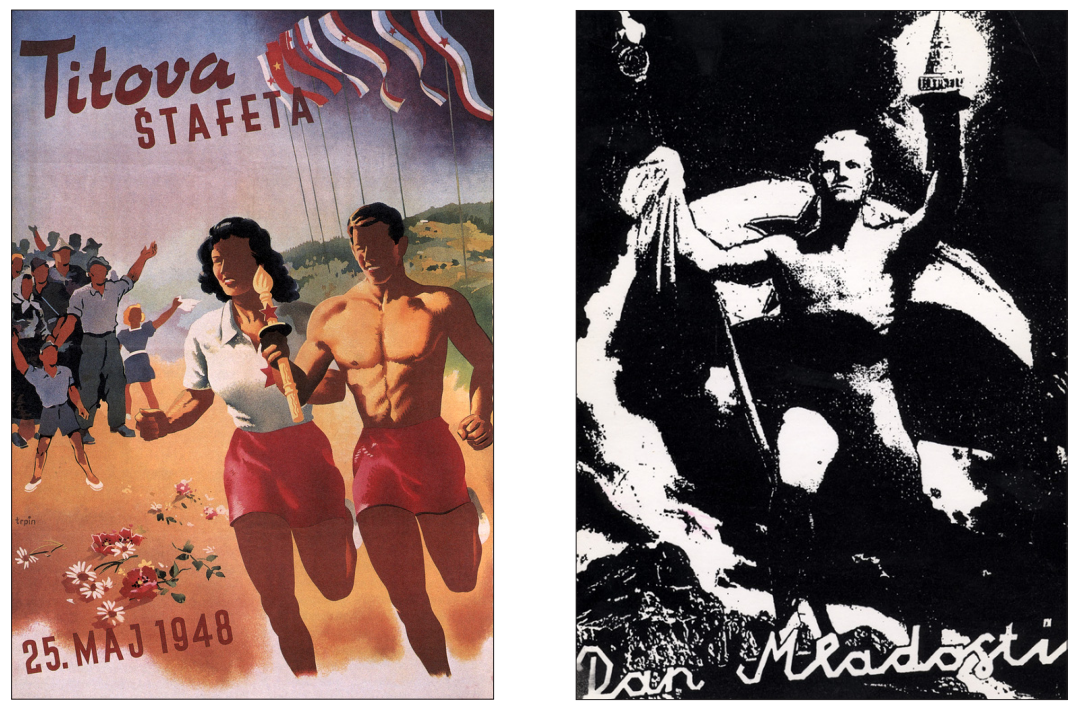

Figure 2. Posters for Youth Day from 1948 (http: / / www.delo.si/druzba/panorama/titovastafeta-in-dan-mladosti.html) and 1987 (http: / / www.mladina.si/109360/no-fear-no-f-hrer/).

The new holidays celebrated the fight for freedom (such as Combatants' Day and days of uprising against the Axis powers in each republic at the beginning of the Second World War), the new country and communism as 'the best system in the world' (Republic Day), its army (Yugoslav People's Army Day), its leader (Youth Day, Tito's Birthday), and the brotherhood and unity of the Yugoslav nations. The first three days were public holidays. There were two days off for Republic Day, New Year, and May 1. There was also a series of memorial days commemorating major victories, important personalities, and events, from the national level to the micro-local level. The celebratory scenarios were very similar: at the national level there were military parades with speeches by Tito and prominent politicians, formal events, and award ceremonies for major achievements in factories, companies, institutions, and schools. Everything was performed in the spirit of re-reading history and re-evaluating the past, and particularly emphasising the achievements of and new challenges to the socialist economy and society. Election days that reinforced the single-party system were also considered major holidays. This ensured that people attended all public celebrations in great numbers. Of course, all this was not specific to Yugoslavia but held true for socialist bloc countries, all of whom had to follow the Soviet model. The features discussed above represent its localised variations. 


\begin{tabular}{|c|c|c|}
\hline Date & Public holiday & Remarks \\
\hline January $1-2$ & New Year & National holiday \\
\hline February 8 & Prešeren Day & $\begin{array}{l}\text { Death anniversary of the Slovenian } \\
\text { poet, established as the national } \\
\text { cultural day in } 1944\end{array}$ \\
\hline April 27 & $\begin{array}{l}\text { Liberation Front } \\
\text { Day }\end{array}$ & In Slovenia \\
\hline May 1-2 & Labour Day & $\begin{array}{l}\text { National holiday, work-free from } \\
1949 \text { onwards; renamed in } 1947\end{array}$ \\
\hline May 9 & Victory Day & $\begin{array}{l}\text { Commemorating the end of the Second } \\
\text { World War, established in } 1945\end{array}$ \\
\hline May 25 & $\begin{array}{l}\text { Tito's Birthday / } \\
\text { Youth Day }\end{array}$ & $\begin{array}{l}\text { Established in } 1945 \text {, renamed in } \\
1957\end{array}$ \\
\hline July 4 & Combatant Day & National holiday \\
\hline July 22 & $\begin{array}{l}\text { Slovenian Uprising } \\
\text { Day }\end{array}$ & Established in 1951 \\
\hline November 1 & Deceased Day & National holiday \\
\hline $\begin{array}{l}\text { November } \\
29-30\end{array}$ & Republic Day & Established in 1944 \\
\hline December 22 & $\begin{array}{l}\text { Yugoslav People's } \\
\text { Army Day }\end{array}$ & \\
\hline
\end{tabular}

Figure 3. Public holidays in Yugoslavian calendar in 1945-1991. The shaded holidays were celebrated only in Slovenia.

The unease and hesitation of people directing the holidays were noticeable in case of those that were widespread in the past: Christmas, for example, was still marked red in calendars for several years after the war and people could choose whether they wanted to celebrate it or go to work. After 1952 it disappeared from the calendar, which does not mean that people ceased to celebrate it; they only did so in their family circles. Newspapers reported absenteeism on the day and how people bought all the goods in stores before Christmas so that nothing was left for the New Year. New measures were introduced swiftly: Christmas trees were renamed 'New Year's trees', stores were only supplied with goods after December 25, and New Year celebrations began to be fostered systematically: the 
ritual components of Christmas (decorations, greetings, gifts brought by Father Frost imported from the Soviet Union, who replaced Santa Claus and Saint Nicholas) were shifted to the last days of the year, and the two New Year days that symbolised the socialist optimism and progress. Special committees, formed like pyramid schemes from the Central Committee of the Communist Party to local celebration committees, were responsible for directing these as well as all other celebrations (Sklevicky 1988; Rihtman-Auguštin 1990; Repe 1999; Slavec Gradišnik 2013a).

The strategy of renaming holidays was more sophisticated and tried to conceal the authentic meanings of older holidays as in the case of March 8, May 1, and November 1.

March 8, International Women's Day, was renamed Women's Day, and was later also

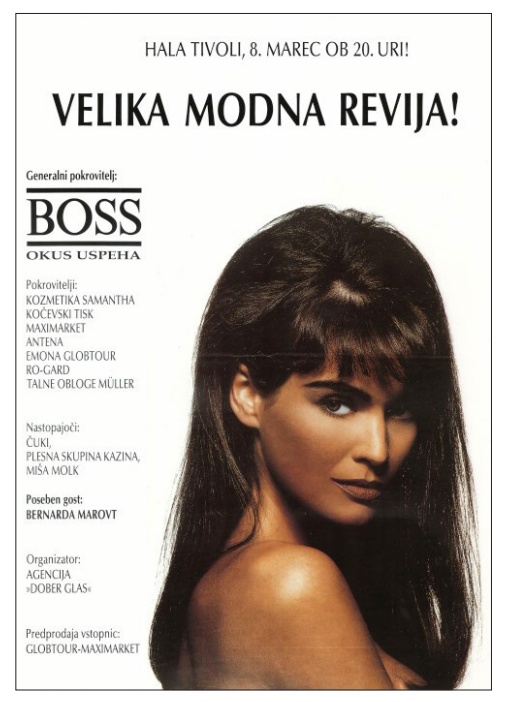

Figure 4. Poster of a fashion show on March 8, 1994 (with a special guest, a famous model) (http:/ / www. dlib.si / ?URN=URN:NBN:SI:imgW8H867EW). interpreted as Mother's Day. Its celebrations took ambivalent forms and meanings: in official ceremonial gatherings, where “[s] peeches on [---] women's struggle for equality were read in combination with rhetoric associated with the directly-linked political campaign, choirs singing revolutionary songs. [---] [A]s time passed, there were fewer and fewer participants in these ceremonial observances. But that does not mean that people had not accepted Women's Day. It was celebrated wholeheartedly, but in an unexpected manner. [---] men as well as women increasingly accepted Women's Day as an opportunity to have a good time. [---] [M]en working at enterprises brought their female fellow-workers inexpensive bunches of flowers [---], and they were treated in return to sandwiches, cake and the obligatory drinks. [---] During the 1960s, the number of variants of the celebration still increased. Some companies gave their women a day off. In later, more prosperous years, companies organised March 8 excursions for their female employees [---] to some nearby spas or recreation centres, but in case the company was a richer one, it organised shopping trips to as far away as Trieste or Graz, and even to London. [---] well-dressed women enjoyed themselves, did a bit of drinking, and danced together. Men were, in any case, excluded, according to the old rituals of the Weiberzechen, the one-day mediaeval Carnival drinking sprees for women only. [---] Against the background of the 1970s' consumer society, towards which the former Yugoslavia was rushing head-on, [---] March 8 increasingly became 
a one-day carnivalesque inversion of the reality in which male dominance, in spite [sic] of the revolutionary dreams, did not disappear. It was a tradition, a step outside of everyday life and a release valve for women's frustrations, which was followed the next day by social relations and male/female relations restored to 'normality'. The strictly criticised 'celebration' of Women's Day thus helped in the functioning of the system, but, paradoxically, it helped even more to maintain - and I would even say, humanise - the bureaucratically dull and boring invented tradition concept. The 'celebration' of March 8 fitted in with the socialist modernisation of society, and even gave an inkling of the post-modern understanding of life" (Rihtman-Auguštin 2001: 4-5).

In 1947, by renaming International Workers' Day Labour Day, the communist regime appropriated and suppressed its social democratic tradition. All Saints' Day was renamed the Deceased Day. This is a typical example of de-Christianisation and secularisation of this public holiday, as is the case also with Christmas. However, All Saints' Day and Christmas also kept their 'folk', traditional, or popular forms of celebration in the private sphere. In the case of Prešeren Day, renamed Slovenian Culture Day, one may observe ideological preferences for common values versus individual creativity.

As the authorities were well aware of the importance of traditional folk culture, some of its elements decorated the scenery of official celebrations. For example, participants dressed in folk costumes, traditional dishes served at receptions, and staged folklore became an important embellishment of the developing tourism in urban and rural areas, sometimes also with the assistance of ethnographers.

\section{THE FESTIVE BRICOLAGE IN CONTEMPORARY SLOVENIA}

In the period between the plebiscite for independence (December 1990) and the declaration of independence (June 1991), Slovenia found itself in a 'holiday mess'. Officially, all Yugoslav and Slovenian national holidays were still in force, but mostly devoid of their ideological significance.

The new Public Holidays Act (as of November 21, 1991) ${ }^{9}$ eliminated all socialist holidays. This act confirmed the following former holidays: New Year (January 1-2), Prešeren Day (February 8), Liberation Front Day (April 27), Labour Day (May 1), Victory Day (May 9) ${ }^{10}$, and the Deceased Day (November 1). Some traditional religious holidays have acquired the status of work-free days: Easter Sunday and Monday, the Assumption, and Christmas mark the re-Christianisation of the public calendar. The new central national holidays are June 25 (Statehood Day) and December 26 (Independence and Unity Day); 
also new is Reformation Day, celebrating the importance of Martin Luther and the Reformation of Slovenian culture (there are approximately twenty thousand Lutherans in Slovenia), and since 2005 there are three other holidays commemorating the major events in Slovenian history that are not work-free days: Day of Slovenians in Prekmurje Incorporated into the Mother Nation (August 17), Day of Restoration of the Littoral Region to the Motherland (September 15), and Rudolf Maister Day (November 23), commemorating his fight against Austria for Slovenia's northern border at the end of the First World War.

\begin{tabular}{|c|c|c|}
\hline Date & Public holiday & Remarks \\
\hline January $1(-2)\left(\mathrm{WF}^{11}\right)$ & New Year & $\begin{array}{l}\text { National holiday; until } \\
2013 \text { two work-free days }\end{array}$ \\
\hline February 8 (WF, 1991-) & $\begin{array}{l}\text { Prešeren Day, } \\
\text { Slovenian } \\
\text { Cultural Holiday }\end{array}$ & $\begin{array}{l}\text { National holiday; } \\
\text { anniversary of the death } \\
\text { of Slovenian poet France } \\
\text { Prešeren, established as } \\
\text { a Slovenian cultural day } \\
\text { in } 1944\end{array}$ \\
\hline March/April (WF, 1992-) & $\begin{array}{l}\text { Easter Sunday } \\
\text { and Monday }\end{array}$ & Dates vary \\
\hline April 27 (WF) & $\begin{array}{l}\text { Day of Uprising } \\
\text { Against } \\
\text { Occupation }\end{array}$ & $\begin{array}{l}\text { National holiday; } \\
\text { renamed (formerly } \\
\text { Liberation Front Day) }\end{array}$ \\
\hline May 1-2 (WF, 1949-) & $\begin{array}{l}\text { Labour Day / } \\
\text { May Day }\end{array}$ & National holiday \\
\hline May/June & Whitsunday & \\
\hline June 8 (not WF, 2010-) & $\begin{array}{l}\text { Primož Trubar } \\
\text { Day }\end{array}$ & National holiday \\
\hline June 25 (WF, 1992-) & Statehood Day & $\begin{array}{l}\text { National holiday, } \\
\text { celebrates the } \\
\text { independence of Slovenia } \\
\text { in } 1991\end{array}$ \\
\hline August 15 (WF, 1992-) & Assumption Day & \\
\hline $\begin{array}{l}\text { August } 17 \text { (not WF, } \\
2006-\text { ) }\end{array}$ & $\begin{array}{l}\text { Day of Slovenes in } \\
\text { Prekmurje Incor- } \\
\text { porated into the } \\
\text { Mother Nation }\end{array}$ & National holiday \\
\hline
\end{tabular}




\begin{tabular}{|c|c|c|}
\hline $\begin{array}{l}\text { September } 15 \text { (not WF, } \\
2005-\text { ) }\end{array}$ & $\begin{array}{l}\text { Day of Restoration } \\
\text { of the Littoral } \\
\text { Region to the } \\
\text { Motherland }\end{array}$ & National holiday \\
\hline October 31 (WF, 1992-) & Reformation Day & National holiday \\
\hline November 1 (WF) & $\begin{array}{l}\text { Day of Commemo- } \\
\text { ration of the Dead } \\
\text { (All Saints' Day) }\end{array}$ & $\begin{array}{l}\text { National holiday; } \\
\text { renamed (formerly the } \\
\text { Deceased Day) }\end{array}$ \\
\hline $\begin{array}{l}\text { November } 23 \text { (not WF, } \\
2005-\text { ) }\end{array}$ & $\begin{array}{l}\text { Rudolf Maister } \\
\text { Day }\end{array}$ & National holiday \\
\hline December 25 (WF, 1992-) & Christmas & $\begin{array}{l}\text { Abolished in } 1953, \\
\text { reinstituted in } 1991\end{array}$ \\
\hline December 26 (WF, 1991-) & $\begin{array}{l}\text { Independence and } \\
\text { Unity Day }\end{array}$ & $\begin{array}{l}\text { National holiday; } \\
\text { celebrates the } \\
\text { proclamation of the } \\
\text { independence plebiscite } \\
\text { results in } 1990\end{array}$ \\
\hline
\end{tabular}

Figure 5. Public holidays in post-socialist calendar. The shaded holidays were introduced in the newly independent Slovenia after $1991 .{ }^{12}$

When adopting old and new holidays, the government and the parliament were unable to avoid polarisation into the political left and right: religious holidays were disputed, some saying there were too many. However, the discussion about Liberation Front Day, that is, about its anti-imperialist or liberating nature, was particularly turbulent. It was defended by the Lefts and opposed by the Rights. The holiday was kept, but was renamed Day of Uprising against Occupation [sic], the argument being that the uprising against the Axis powers during the Second World War was the only event to commemorate in this crucial time in Slovenian history. Opponents have expressed their disagreement with the holiday by ignoring celebrations, which also occurs with some other public holidays. Another holiday that met opposition was the celebration of Victory Day on May $9^{13}$, because many people considered the end of the war to be the beginning of the totalitarian communist regime and massacres of the opponents of communism. The holiday was removed or deleted from the calendar in 1991 by the Act on Holidays and Days Off. However, this day has also been 
the traditional holiday of the City of Ljubljana for decades. It is still celebrated today as a mix of the liberation holiday and city holiday. The same day has also been Europe Day since 1994, commemorating the Schuman Declaration of 1950, which initiated the concept of the European Union, and is celebrated today as a day of unity and peace in Europe. ${ }^{14}$

At this level, holidays have remained an arena of political conflict and struggle for interpretation, therefore often indirectly dividing rather than integrating the citizens of Slovenia, which is also due to the ideological commitment of the media, working in either direction. This is accompanied by re-readings and revaluations of history.

But how does it concern the citizens? Holidays dictate the annual rhythm and periods that people can spend in a way different from their everyday work. In a democratic country, they can decide whether and how they want to celebrate them.

Towards the end of the socialist period, people would often take off the entire period from April 27 to May 1 (by taking a holiday or substituting work days in advance); today to the majority of people an entire week off matters more than the political or social charge (particularly as school vacation falls on the same week).

The character and content of holidays and the expected intensity of celebration is connected with the position of the new holidays in the calendar. Under socialism, new holidays were placed on the calendar before or after important holidays (e.g. New Year, which was intended to cover and replace Christmas), and the new post-communist holidays have also been placed near them, which has the effect that attention to their content is diffused and is also considerably smaller. This is one of the difficulties in the discussions about how the new national holidays are (or are not) rooted, although the most frequent response is that their tradition is still not very strong. Thus, for example, the national holiday on June 25 is placed next to Midsummer Day, when schools close for the summer and many people go on holiday. Reformation Day on October 31 and the Deceased Day on November 1 remain mainly commemorative. However, in the last decade, for many younger people October 31 has become the date for Halloween parties, which has completely overshadowed the meaning of the last day of October and first day of November for part of the population. In December, Independence Day (December 26) follows Christmas, and December 26 is also Saint Stephen's Day, a folk holiday that has recently again been celebrated by quite a large number of people, both in church and at numerous local events. The period between Christmas and New Year offers opportunities for various celebrations within the family, at public venues, or even in faraway foreign countries. 
In 2012, when it was clear that Slovenia was faced with a deep economic, political, and social crisis, the government announced the abolition of two days off work (January 2 and May 2). The argument was based on savings for the economy, as well as the comparison that nowhere else in Europe these two holidays are celebrated over two days, the exception being 'some rigid Eastern European countries'. People's responses published in digital media were interesting: the content of holidays was rarely questioned, the prevailing theme being the opposition to taking away from those that already had less than others or even nothing. Therefore a holiday, even if it is not a political one in the strict sense of the word, is not a neutral calendrical fact, but the arena of social opposition and competition, whether it involves religion (propositions to abolish religious holidays) or enlightenment, when speaking of 'nearing', 'adapting', or 'unifying' - in this case, towards 'progressive' Europe. In the case mentioned, the dimension is also explicitly social because the holidays are also taken from those that are in greater need of the day off.

Finally, national holidays have become an arena of expressing social discontent, with high unemployment, a threat of job loss, insecure existence, and lowest ever salaries. The following two double celebrations illustrate this point.

Independence and Unity Day on December 26, 2012, was marked by an official celebration. Meanwhile, the supporters of the 'first Slovenian uprising' gathered in the city streets and squares to express their political and social demands while carrying banners (such as "The authorities are parading, the people starving!"), and were labelled 'zombies' by the former prime minister.

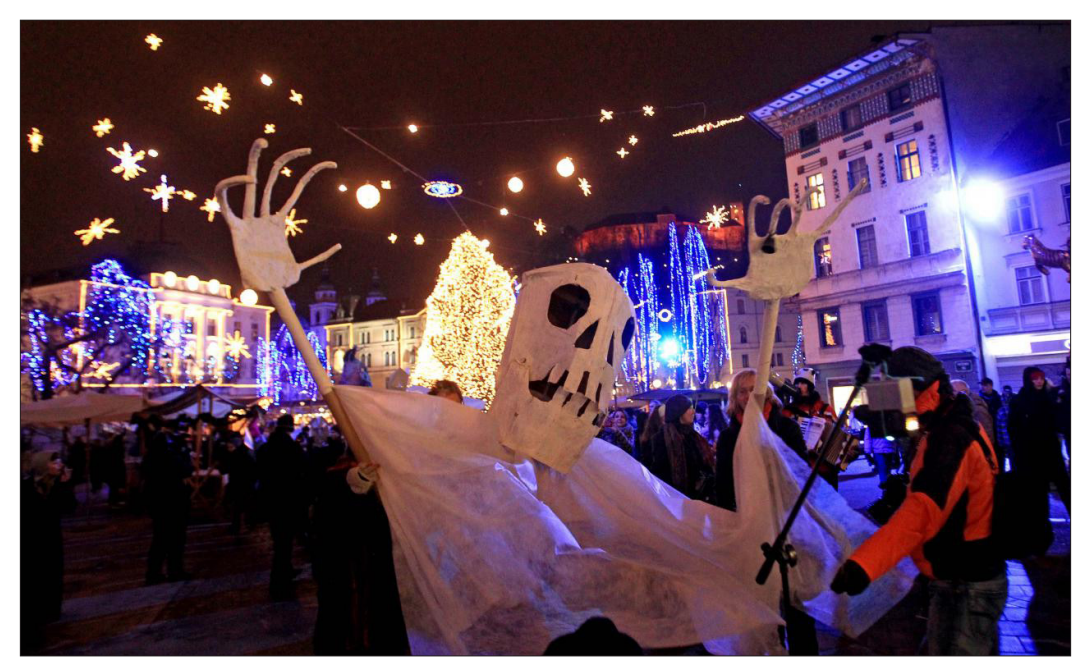

Figure 6. 'Zombies' in Ljubljana in December 2012, during the 'first Slovenian uprising'. Photograph from daily journal Slovenske Novice (http:/ / www.slovenskenovice.si/novice/ slovenija / na-kongresnem-trgu-so-se-zbrali-kulturni-zombiji). 


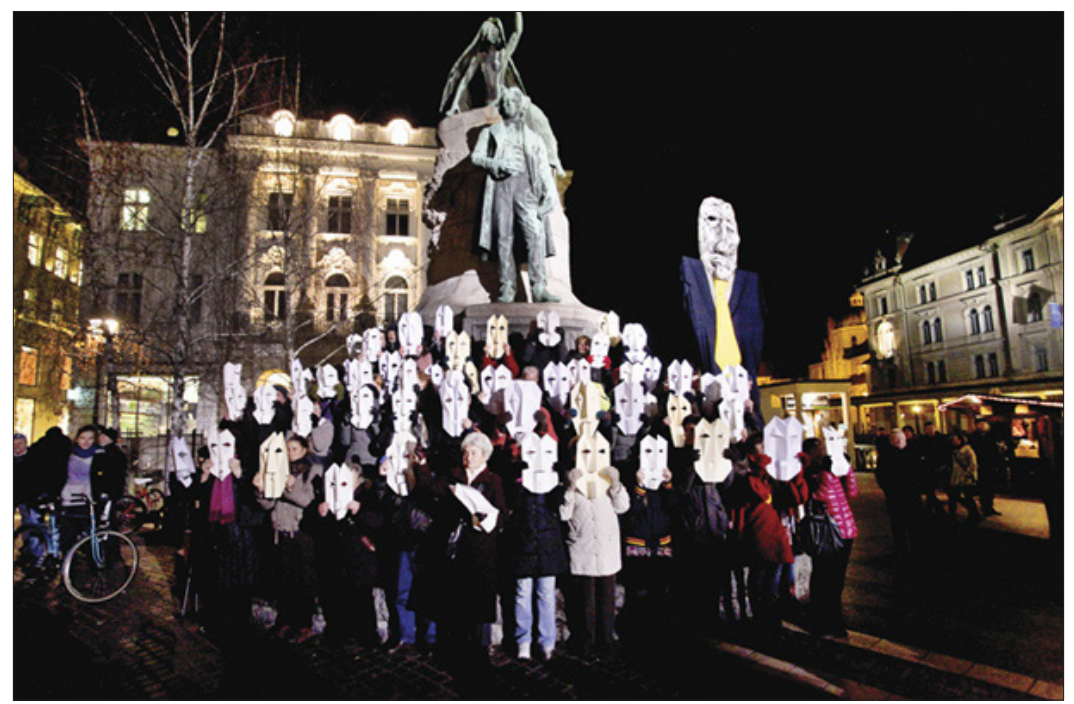

Figure 7. 'Zombies' in front of Prešeren monument in Ljubljana in 2013, during the 'third Slovenian uprising'. Photograph from weekly journal Mladina (http: / / www.mladina.si / media / www/slike/2013/03/_610/marcel-zombiji-prese.jpg).

Another double celebration occurred on Prešeren Day in 2013. The Committee for the Republic expressed its support for the prime minister, who labelled the ideology of those revolting as 'leftist fascism', while protesters wearing masks to conceal their 'zombie identity' gathered at the Prešeren Monument in Ljubljana.

Alternative practices of celebrating former communist holidays (in the sense of anti-holidays, organised bottom-up) have not been completely devoid of ideology in Slovenia. In this manner, smaller social and generational groups still celebrate holidays such as Youth Day and Republic Day. Interpretations vary: glorification of the symbols of the totalitarian regime, Yugo-nostalgia, being different, opposition to current nationalist and neoliberal discourses in which old symbolism takes the position of criticising the new, pure fun, a consumer niche market, and a pop-cultural phenomenon (cf. Velikonja 2013). Their arenas are not only public spaces, but also the cyberspace (Facebook, Twitter, YouTube).

\section{TRANSCENDING NATIONAL POLITICS}

However, the calendar with its unofficial, new, and traditional holidays also makes it possible to express different interests and identities, not only political ones. Global phenomena - mass and consumer culture, mass and especially digital media, and tourism and heritage industry, to name just a few - and, 
on the other hand, the significance of local traditions vitally shape the festive landscape in Slovenia today (cf. Bogataj 2011; Slavec Gradišnik 2013b).

Today, a variety of overlapping, hybrid identities that are created at the levels of family and kinship, locality and regions, generations, interest and other groups, are often more important than the 'great' affiliation (to the country or nation).

Traditional cultural models serve as the reproduction of locality (urban and rural) and the desired representation of authenticity, and they help map selfrepresenting, self-expressing, symbolic, promotional, and economic interests. ${ }^{15}$ Traditional holidays (carnival, local patron saints' feast days, and holidays in December) very often assimilate the grammar of popular and consumer culture. The 'imported' holidays - such as Valentine's Day or Halloween ${ }^{16}$ - fit into the model of popular culture and highlight public and scholarly discussions on local traditions and global phenomena, on holidays as market commodities (because holidays are not meant exclusively for the redistribution of values, but also money), and on the essence of holidays when it seems that the boundaries between local and global identities are being increasingly blurred.

Contemporary holidays and rituals defy typologies and definitions: many of them embody factual, imagined, and reinvented traditions, and because of their fluid, overlapping, heteroglossic, and contested meanings they remain a challenge for future research that can be related to processes of social inclusion and exclusion, remembering and forgetting, uses of cultural heritage, enculturation processes, rural-urban boundaries, global and local contexts, imposed and creative aspects, and, above all, holiday and ritual agents that are involved in the (re)production of social and cultural meaning and values.

\section{NOTES}

1 This article is part of a research carried out through the project Holidays and Constitution of National Community in Slovenia (J6-4007, 2011-2014, project leader: Božidar Jezernik, Faculty of Arts, University of Ljubljana; funded by the Slovenian Research Agency). The focus has been to "examine the complex and multifaceted relationships of mutual constitution of the holidays and identities of social groups [---] identifying and relating the factors that constitute the holidays, and answer the questions of how specific social groups are involved in the process of constituting the holidays, how they identify themselves with them, and what values make sense of the holidays" (Holidays 2010: 13).

${ }^{2}$ For a discussion on ritual efficacy, see Sax \& Quack \& Weinhold (2010). 
${ }^{3}$ I understand rituals as the main instrument that carries the content of holidays. Alongside difficulties in defining exactly what a ritual is (cf. Snoek 2008), I rely on the definition of a fuzzy set of phenomena based on social similarities or, following Wittgenstein's "family resemblance" (Wittgenstein1953: § 65-71; cf. http://en.wikipedia.org/wiki/ Family_resemblance) as proposed by Stanley Tambiah (1979: 119): a "patterned and ordered sequence of words and acts, often expressed in multiple media, whose content and arrangement are characterized in varying degree by formality (conventionality), stereotypy (rigidity), condensation (fusion), and redundancy (repetition)". These characteristics, 'obligatory' to different extents, are oriented toward interpreting the ritual as a form of practice. For more detailed elements of the ritual, see Snoek (2008: 11).

4 This topic is also part of the research project mentioned above (see note 1), through which the book Politika praznovanja (The Politics of Celebration; Jezernik 2013c) was published, and last year we held an international conference under the heading State and National Holidays in the Former Yugoslavia Between the Nineteenth and Twenty-First Centuries (Slavec Gradišnik \& Jezernik \& Strmčnik 2014).

5 Kingdom of Serbs, Croats and Slovenians from 1918, Kingdom of Yugoslavia from 1929.

6 The most important religious and popular holidays were Epiphany, Candlemas, Shrove Tuesday, Easter, Pentecost, Corpus Christi, Midsummer Night, the Nativity of Mary, the Assumption, All Saints' Day and All Souls' Day, Martinmas, Saint Nicholas' Day, Christmas, Saint Stephen's Day, and New Year, and of course celebrating the feast days of the parish patron saint or local patron saints.

7 Josip Broz Tito was actually born on May 7. The explanations for why the celebration was held on May 25 are contradictory (e.g. the significance of being 'born again' on May 25, which Tito is said to have ascribed to the fact that he survived the raid at Drvar on that day, or Tito hiding his true identity in falsified documents in which his birth date was given as May 25). For more on this, see Škrbić Alempijević \& Mathiesen Hjemdahl 2006.

8 The national system based entitlement on the moral capital of resistance to the Axis forces and connected it with a new social order organised following the ethics of socialism and equality. This especially took hold of a large part of the industrial and agrarian proletariat, who lived in great poverty before the war. The economically better and socially more secure position for the majority of the population offset the lack of democratic rights and freedoms (Makarovič 1995: 307).

9 The Act on Holidays and Days Off was amended in 2005 and 2010.

10 This holiday was not included in the official calendar, but was and still is celebrated.

${ }^{11} \mathrm{WF}=$ work-free day.

12 The official national calendar differentiates between two categories of holidays: public holidays in the Republic of Slovenia and work-free days. With some exceptions (June 8, August 17, September 15, and November 23), those under the first category are work-free days, which include Easter Sunday and Monday, Pentecost Sunday, the Assumption, Reformation Day, and Christmas (http://www.vlada.si/o_sloveniji/ politicni_sistem/prazniki/, last accessed on January 21, 2015). 
13 The Second World War actually ended on May 8, 1945 (May 9, Moscow time). In Yugoslavia the date of the celebration was shifted to May 9 (it was on that day when the victorious Partisans entered Ljubljana). After the split with the Stalinist Soviet Union, Victory Day was celebrated on May 15 from 1952 to 1965; namely, the German act of surrender in Yugoslavia was signed in Topolšica on May 15, 1945, and followed the last battle of the Second World War in Poljana near Prevalje (Batista 2013: 47).

${ }^{14}$ Europe Day has not been without controversy regarding its status either. It was originally conceived by the Council of Europe and not the Council of the European Union. Namely, in 1964, the Council of Europe proposed May 5, the date of its founding in 1949 , as the date of the holiday.

${ }^{15}$ For a more complete picture of holidays and celebrations in Slovenia today, see Bogataj (2011).

${ }^{16}$ With the aid of the mass media and popular culture iconography, Valentine's Day began to take root in Slovenia in the 1990s, with Halloween following soon thereafter. Both holidays express the universal dichotomy between life, love (Valentine's Day) and death (Halloween), which facilitates their linking to traditional roots (cf. Komel 2014). As far as contemporary holiday practices are concerned, Valentine's Day speaks to a broader spectrum of social actors, while Halloween appeals primarily to the younger generation. The ritual of gift-giving is in the centre of Valentine's Day celebrations, which is why its consumerist nature is so emphasised. Halloween foregrounds quasimagical elements (witches, witchcraft), which is reflected in staged and costumed social events and parties.

\section{REFERENCES}

Batista, Eva 2013. Dan zmage nad fašizmom in nacizmom, 9 maj 1945: Praznovanja v Ljubljani med letoma 1945 in 2005. [Victory Day over Fascism and Nazism, May 9, 1945: Celebrations in Ljubljana 1945-2005.] In: B. Jezernik (ed.) Politika praznovanja: Prazniki in oblikovanje skupnosti na Slovenskem. [The Politics of Celebration: Holidays and Shaping the Community in Slovenia.] Ljubljana: Znanstvena založba Filozofske fakultete, pp. 47-68.

Bell, Catherine 1992. Ritual Theory, Ritual Practice. Oxford \& New York: Oxford University Press.

Bell, Catherine 1997. Ritual: Perspectives and Dimensions. Oxford \& New York: Oxford University Press.

Bell, Catherine 2008. Embodiment. In: J. Kreinath \& J. Snoek \& M. Stausberg (eds.) Theorizing Rituals: Classical Topics, Theoretical Approaches, Analytical Concepts. Leiden \& Boston: Brill, pp. 533-543.

Bogataj, Janez 2011. Slovenija praznuje. Šege in navade na Slovenskem. [Slovenia Celebrates: Customs and Habits in Slovenia.] Ljubljana: Mladinska knjiga.

Bourdieu, Pierre 1977. Outline of a Theory of Practice. Cambridge: Cambridge University Press.

Bourdieu, Pierre 1990. The Logic of Practice. Stanford: Stanford University Press. 
Holidays $2010=$ Holidays and Constitution of National Community in Slovenia: Project proposal. Available at http://www.sicris.si/public/jqm/prj.aspx?lang=eng\&opdesc $\mathrm{r}=$ search\&opt=2\&subopt $=400 \& \operatorname{code} 1=\mathrm{cmn} \& \operatorname{code} 2=$ auto $\&$ psize $=1 \&$ hits $=1 \&$ page $=1 \&$ count $=\&$ search_term $=$ jezernik $\% 20 \mathrm{bo} \% \mathrm{C} 5 \%$ BEidar\&id=7004\&slng=\&order by=, last accessed on March 9, 2015.

Jezernik, Božidar 2013a. Politika praznovanja. [The Politics of Celebration.] In: B. Jezernik (ed.) Politika praznovanja: Prazniki in oblikovanje skupnosti na Slovenskem. [The Politics of Celebration: Holidays and Shaping the Community in Slovenia.] Ljubljana: Znanstvena založba Filozofske fakultete, pp. 7-16.

Jezernik, Božidar 2013b. Temeljni kamen spotike: Vidov dan med Slovenci. [The Foundation of Contention: Saint Vitus' Day in Slovenia.] In: B. Jezernik (ed.) Politika praznovanja: Prazniki in oblikovanje skupnosti na Slovenskem. [The Politics of Celebration: Holidays and Shaping the Community in Slovenia.] Ljubljana: Znanstvena založba Filozofske fakultete, pp. 17-46.

Jezernik, Božidar (ed.) 2013c. Politika praznovanja: Prazniki in oblikovanje skupnosti na Slovenskem. [The Politics of Celebration: Holidays and Shaping the Community in Slovenia.] Ljubljana: Znanstvena založba Filozofske fakultete.

Komel, Mirt 2014. Eros forme in Thanatos vsebine. Potrošniško praznovanje valentinovega in noči čarovnic na Slovenskem. [Eros of Form and Thanatos of Content: Consumerist Celebration of Valentine's Day and Halloween in Slovenia.] In: I. Slavec Gradišnik (ed.) Praznična večglasja: Prazniki in oblikovanje skupnosti na Slovenskem. [Holiday Polyphony: Holidays and Shaping the Community in Slovenia.] Ljubljana: Znanstvena založba Filozofske fakultete, pp. 91-108.

Makarovič, Gorazd 1995. Slovenci in čas: Odnos do časa kot okvir in sestavina vsakdanjega življenja. [Slovenians and Time: The Relation to Time as a Frame and Element of Everyday Life.] Ljubljana: Krtina.

Melik, Vasilij 1999. Obdobje 1918-1941. [The Period 1918-1941.] In: F. Rozman \& V. Melik \& B. Repe (eds.) Zastave vihrajo: Spominski dnevi in praznovanja na Slovenskem od sredine 19. stoletja do danes. [The Flags Boldly Wave: Memorial Days and Celebrations in Slovenia from the Mid-19th Century to Today.] Ljubljana: Modrijan, pp. 58-104.

Moore, Sally F. \& Myerhoff, Barbara G. 1977. Introduction: Secular Ritual: Forms and Meanings. In: S. F. Moore \& B. G. Myerhoff (eds.) Secular Ritual. Assen: Van Gorcum, pp. 3-24.

Repe, Božo 1999. Obdobje 1945-1990. [The Period 1945-1990.] In: F. Rozman \& V. Melik \& B. Repe (eds.) Zastave vihrajo: Spominski dnevi in praznovanja na Slovenskem od sredine 19. stoletja do danes. [The Flags Boldly Wave: Memorial Days and Celebrations in Slovenia from the Mid-19th Century to Today.] Ljubljana: Modrijan, pp. 145-181.

Rihtman-Auguštin, Dunja 1990. Metamorfoza socijalističkih praznika. [Metamorphosis of Socialist Holidays.] Narodna umjetnost, Vol. 27, No. 1, pp. 21-32. Available at http://hrcak.srce.hr/index.php?show=toc\&id_broj=4455, last accessed on January 21, 2015.

Rihtman-Auguštin, Dunja 2001. About the Control of Rhythms of Time. EthnoAnthropoZoom, Vol. 2, pp. 1-8. Available at http://www.iea.pmf.ukim. edu.mk/EAZ/EAZ_01/Rihtman_Augushtin_EAZ_01_ang.pdf, last accessed on February 9, 2015. 
Rozman, France 1999. Prvomajska praznovanja. [May Day Celebrations.] In: F. Rozman \& V. Melik \& B. Repe (eds.) Zastave vihrajo: Spominski dnevi in praznovanja na Slovenskem od sredine 19. stoletja do danes. [The Flags Boldly Wave: Memorial Days and Celebrations in Slovenia from the Mid-19th Century to Today.] Ljubljana: Modrijan, pp. 16-21.

Santino, Jack 1996. New Old-Fashioned Ways: Holidays and Popular Culture. Knoxville: University of Tennessee Press.

Sax, William S. \& Quack, Johannes \& Weinhold, Jan (eds.) 2010. The Problem of Ritual Efficacy. Oxford \& New York: Oxford University Press.

Simonič, Peter 2000. O delavstvu in prazniku. [Workers and Holidays.] Dialogi, Vol. 36, Nos. 5-6, pp. 30-49.

Sklevicky, Lydia 1988. Nova Nova godina - od 'Mladog ljeta' k političkom ritualu. [The New New Year: From Christmas to Political Ritual.] Etnološka tribina, Vol. 18, No. 11, pp. 59-72. Available at http://hrcak.srce.hr/index.php?show=clanak\&id_ clanak_jezik=119507, last accessed on January 22, 2015.

Slavec Gradišnik, Ingrid 2013a. Ubrani in razglašeni decembrski čas. [Harmonious and Dissonant December Times.] In: I. Slavec Gradišnik (ed.) Praznična večglasja: Prazniki in oblikovanje skupnosti na Slovenskem. [Holiday Polyphony: Holidays and Shaping the Community in Slovenia.] Ljubljana: Znanstvena založba Filozofske fakultete, pp. 133-163.

Slavec Gradišnik, Ingrid (ed.) 2013b. Praznična večglasja: Prazniki in oblikovanje skupnosti na Slovenskem. [Holiday Polyphony: Holidays and Shaping the Community in Slovenia.] Ljubljana: Znanstvena založba Filozofske fakultete.

Slavec Gradišnik, Ingrid \& Jezernik, Božidar \& Strmčnik, Marjana (eds.) 2014. Držauni in narodni prazniki na območju bivše Jugoslavije med 19. in 21. stoletjem. Spored konference in povzetki / State and National Holidays in the Former Yugoslavia between the Nineteenth and Twenty-First Centuries: Conference Programme and Abstracts. Ljubljana: ZRC SAZU, Inštitut za slovensko narodopisje.

Snoek, Jan A. M. 2008. Defining 'Rituals'. In: Jens Kreinath \& Jan Snoek \& Michael Stausberg (eds.) Theorizing Rituals: Classical Topics, Theoretical Approaches, Analytical Concepts. Leiden \& Boston: Brill, pp. 3-14.

Škrbić Alempijević, Nevena \& Hjemdahl, Kirsti M. (eds.) 2006. O Titu kao mitu: Proslava Dana mladosti u Kumrovcu. [On Tito as a Myth: Celebration of Youth Day in Kumrovac.] Zagreb: Filozofski fakultet \& Srednja Europa.

Tambiah, Stanley J. 1979. A Performative Approach to Ritual. Proceedings of the British Academy, Vol. 65, pp. 113-169.

Turner, Victor W. 1969. The Ritual Process: Structure and Anti-Structure. London: Routledge and Kegan Paul.

Velikonja, Mitja 2013. Jugoslovenija: Slavljenje nekdanjih jugoslovanskih praznikov v sodobni Sloveniji. [Yugoslovenia: Celebrating Former Yugoslav Holidays in Contemporary Slovenia.] In: B. Jezernik (ed.) Politika praznovanja: Prazniki in oblikovanje skupnosti na Slovenskem. [The Politics of Celebration: Holidays and Shaping the Community in Slovenia.] Ljubljana: Znanstvena založba Filozofske fakultete, pp. 111-133.

Wittgenstein, Ludwig 1953. Philosophical Investigations. Oxford: Blackwell. 


\title{
POLITICAL RITUALS AND DISCOURSES: THE CASE OF CARINTHIA
}

\author{
Jurij Fikfak
}

\begin{abstract}
This article discusses selected ritual practices in Klagenfurt (Sln. Celovec), the capital of the southernmost Austrian state of Carinthia (Germ. Kärnten). The first ritual is connected with October 10, when the 1920 plebiscite is commemorated on the streets of Klagenfurt. In this plebiscite, the majority of people voted for remaining a part of Austria, the successor state to Austria-Hungary. The second ritual is a more recent one, known as the Memorial Walk (Germ. Gedenkgehen, Sln. Spominska hoja). Various cultural practices are analysed, as well as the use of symbols and space, media, state, and national discourses.
\end{abstract}

Keywords: alternative practice, memorial walk, Nazism, plebiscite, ritual practices, use of discourse

Political rituals are practices set in concrete chronotopes. They express and materialise a sense of belonging, the formation of identities, and the establishment of local, regional, ethnic, national, or state entities. They also represent an area of social cohesion, self-identification, the marking of social affiliation and the exclusion of the Other. Political rituals are unavoidable in social integration (Lukes 1975), socialisation of hierarchies, relations, and the use of power. They are used repeatedly, year after year, to define, embody, and materialise ethnic, language, and other barriers which do not allow a single person, socialised in any community, to remain unaffected or undecided. As Steven Lukes has put it, political rituals mobilise bias, but they also raise questions about the relationships between different discourses, for example, between the official political discourse of the ruling parties, media discourses, the so-called common sense discourse, and the subcultural discourse present mainly among various extremist groups. Rituals speak to and about society and its institutions, and enable and recreate their extractive or inclusive characters (North 1991).

The dynamics of cognitive bias can be seen and indeed was seen on February 10, during the Memorial Day (Il Giorno del ricordo) in the Trieste region (cf. Fikfak 2009), where, in 2007, an intense interplay of political views was brought to 
light: views expressed even by the Italian president, which included comments about bloodthirsty Slavs, the prevailing political and media discourses on the regional level of the Trieste region, and, finally, the subcultural discourses of a group called Movimento Sociale Fiamma Tricolore or MS FT (Tricolour Flame Social Movement). The MS FT expressed their views by spraying neo-Nazi and neo-fascist graffiti on monuments dedicated to the partisans who died in the Second World War - monuments all along the way from Trebče (Trebiciano) and Padriče (Padriciano) to Boljunec (Bagnoli della Rosandra) (Fikfak 2009). The group's affinity for a neo-fascist discourse was materialised once more during a national Italian holiday on April 25, at a foiba ${ }^{1}$ (cenotaph) in Bazovica (Basovizza), at a place of remembrance dedicated to the exodus of Italians and others from Dalmatia and Istria, and to the Italians and opponents of the communist system who were killed (hundreds of them thrown in foibe) near the end of the war or shortly afterwards.

By presenting politicians with opportunities to consciously select ritual places, events, and appropriate interpretations, political rituals also enable official politics to seize or limit the scope of argumentation of subcultural discourses and activities. Mayors and representatives of municipalities in the Trieste region, both Italian and Slovenian, gather annually on November 1 and pay their respects to the fallen on all sides. In Bazovica, for example, they gather both at the site of remembrance of the foibe victims and at the location where four members of the anti-fascist organisation TIGR were executed in 1930 (Fikfak 2009). The state prescribes and maintains order through its representatives; in doing so, the basic values and guidelines are conveyed, which have a potential to alter other discourses, including trivial, common sense, or subcultural discourses (Hayek 1960).

Such changes and decisions, i.e., the conscious formation of political or dominant discourses intended to prevent future antagonism and bring together the once quarrelling and hostile nations and countries (primarily France and Germany, but other nations and countries as well) also served as the basis for the European idea formulated by Jean Monnet and Robert Schuman. ${ }^{2}$ Implicit to this idea was an attempt to influence the general opinion through official discourse, and then use that general opinion to influence subcultural discourses, since they are the ones that most often re-create unease, opposition and animosity between different groups.

These dynamic relationships between different ruling, media, trivial and subcultural discourses, and between the different practices and materialisations of both memory and identity, are also present in the southernmost Austrian state, Carinthia. 
After the Austro-Hungarian Empire dissolved into several states in 1920, Austrian borders became a major point of contention with Italy and the State of Slovenes, Croats and Serbs (SHS). Italians demanded and received the south of Tyrol and the valley around Tarvisio. On October 10, 1920, a plebiscite was held in Carinthia and Carinthians were asked to decide between Austria and the State of SHS. The majority of both German-speaking and Slovenian-speaking voters opted for the green ballot paper Österreich-Avstrija, and thus chose the main successor state of the Austro-Hungarian Monarchy for their homeland. Slovenians chose Austria primarily for economic reasons (cf. Moritsch 2002), since the entire region naturally gravitated towards Klagenfurt. Their decision was also greatly influenced by the general promise and pledge of the Austrian authorities to protect Slovenian culture and language rights in the region. Another element that should be taken into account is the category of the Windisch or 'Zwischenmenschen', introduced through Martin Wutte (cf. Zinkner 2009; Valentin 2006), which was very successful in addressing the voters, as an element of pro-German Slovenian households.

In the following year, 1921, the result of the plebiscite (Volksabstimmung) that kept Carinthia "free and undivided" was celebrated in a ritual fashion. As Dr. Peter Kaiser, the current Governor of Carinthia and a member of the Social Democratic Party of Austria, wrote in an official communication, even this very first commemoration was distinctly pro-German, and so not only anti-Serbian and anti-Yugoslav, but also anti-Slovenian.

The Carinthian calendar year, news reports, and literature (Burz \& Pohl 2005) all show that the ritualised remembrance of the plebiscite is an event that has little to do with the common ritual calendar (Easter, Christmas, New Year, Fasching (Mardi Gras) sessions). Every year, the anniversary is commemorated in schools. No classes are held on that day and offices are closed as well. State leaders release official statements to the media and lay wreaths at monuments to brambovci, the armed guardsmen who fought to keep Carinthia Austrian, and a commemorative session of the Carinthian Landtag (State Diet) assembly is held. These commemorations tend to be more solemn than the ones marking the national holiday on October 26, which commemorates the day in 1955 when the Declaration of Neutrality was signed by the Austrian Parliament in Vienna. In recent decades, larger celebrations were held mainly every five or ten years. A sort of rationality or economy of ritual is apparent: long processions were held on the streets of Klagenfurt, the centre of Carinthia, in 1995, for the 75th anniversary, in 2000 for the 80th anniversary, and in 2010 for the 90th anniversary of the plebiscite. The next large commemoration event is planned for 2020, and is to mark the centennial anniversary. 
Approximately 20,000 people were reported to have taken part in the 1995 commemorative parade, and 100,000 people came to watch them march by. In 2010, however, when I documented the Festumzug (the festival parade), the procession had only 16,000-17,000 active participants, and an unknown number of spectators. News reports mentioned from 5,000 to more than 10,000 spectators; most were gathered at or near the New Square (Sln. Novi trg; Germ. Neuer Platz), which is the main square in Klagenfurt. A special grandstand was set up on the square and members of the procession marched past the honoured guests of state and church authorities: Austrian President Heinz Fischer, Chancellor Werner Faymann, State Governor Gerhard Dörfler, Bishop of Gurk-Klagenfurt Alois Schwarz, and others. There were no representatives of Slovenian authorities. According to photographs, a single official representative of the Slovenian parties active in Carinthia (Dr. Marjan Sturm) attended the event, ${ }^{3}$ since none of the other parties were invited to participate.

Watching the procession in person, on television or in YouTube videos, and sitting through the DVD video (over seven hours long), paints a relatively uniform portrait of the event characterised by the colours of various Carinthian and a few Austrian flags. The other characteristic colour is the conspicuous brown texture of the local Carinthian costume. The speeches - all in German mainly praise and reaffirm the historic decision for unity and 'undividedness' of Carinthia within the borders of the old and new Republic of Austria, the main successor state of the former Austria-Hungary. There are carriages with large billboards which show historical depictions, almost in the form of a comic book, and either utilise or imitate the artistic moment and solutions that were used in propaganda materials in 1920. They show a brief history of the decisive events that happened after the war, between 1918 and 1920, and conclude with the German triumph at the plebiscite in October 1920.

The impressions gathered in Klagenfurt, and from video-documentation, newspaper reports, and online forums, all indicate that the event is a constituent of the image of the country. Ideal-typically, the Carinthian nature and unity of the land are restored again and again with each commemoration of the 1920 plebiscite.

In determining the basic configuration of the procession, I chose to start my observation at the front and continue towards the back of it. I kept noticing that members of the procession greatly outnumbered the spectators, who watched on the side of the road. The largest numbers gathered at the back of the procession, on the New Square and on the stands reserved for invited guests. According to the information published by newspapers (Kleine Zeitung, Kärntner Zeitung, etc.), approximately 20,000-25,000 people took part in the 
celebrations, which is less than the number of mourners who attended the memorial service for the Governor of Carinthia, Dr. Jörg Haider (attended by more than 30,000). The ratio between active participants on the one side and the spectators on the other speaks to the fact that the parade is organised for the purpose of self-presentation and that it is a ritual in which both participants and spectators, many of whom wear traditional regional brown costumes or dirndls, can reaffirm their self-image. Moreover, in a public space and in full view of the large, predominantly Austrian public and the heads of state and the church, the participants themselves become the materialisation of Carinthia. The population of Carinthia is represented by the 5-6 percent who participate in the event. Their role in the procession in the streets of Klagenfurt, the capital of Carinthia, and their mere presence at the event define the horizon of the Carinthian chronotope, reaffirm the desired view of the world and, in doing so, renew Carinthian identity.

We should bear in mind who self-presents at these sacred, central locations in the capital of Carinthia and how they do it; in what measure are the state (Austrian), ethnic (German or Slovenian) or regional (Carinthian) selfhoods included in such ritual behaviour and activities, and to what extent they need and create a different Other in order to establish the 'Carinthianness'. To what extent do they require or utilise either the indigenous ethnic population, i.e., Slovenians, or foreign immigrants, for example, Chechens?

If we also consider the specific situation in Carinthia with regard to bilingual signposts, school curriculums, the official language, etc. - the basic relationship between the German majority and the Slovenian minority - the issue of different structurations of the general and, in this case, ritual discourses on German and Slovenian sides becomes important. How and where can or could people internalise the Carinthian-German self-presentation, which perceives and recreates its own history as that of the southernmost German border and a bastion of defence between its own, German culture, and foreign, strange Slavs? Or the realistic and mythological self-comprehension of Slovenians, which includes images of Carinthia as a historic centre of the Slovenian people and as the northernmost border of Slovenianness?

Either way, the images and messages conveyed and renewed by the festive event, and the ritual practice of the celebratory parade (Festzug), have become real for people - words have become things (Austin 1962). Past events, memories and traces of the spirit are materialised (Oevermann 2001) in their presentation in front of the most important representatives of national, regional and church authorities. They are also part of the ongoing discussion on online forums and in everyday life. They influence actual decisions on which memories should be 
internalised in schools, in a community or, for example, at a museum, as well as decisions on how that internalisation should be achieved. The spaces where ritual practices occur are true representations; they are the spaces of metonymic metaphors which symbolise unity, supported by red and yellow flags. In a synesthetic way, accompanied by music and a steadfast, almost militaristic self-presentation, these spaces signify and renew the determination to remain pro-German.

\section{KEEPING TRACK OF CHANGES}

This is merely the initial perspective; yet, it is still the dominant one. 1995 brought the first trace of censorship in the standard image, with a speech given in Slovenian at the state assembly. 2010 indicated a further shift in the scenario of self-presentation: the commemorative procession included representatives of local settlements, who carried bilingual signs, written in both Slovenian and German. The reasons for these changes can, of course, be found on the level of political discourses and the relationships between the main actors in Carinthia, which changed following the sudden death of State Governor Dr. Jörg Haider. Another reason for the changes is the very nature of ritual practices and materialisations of political discourses, which are constantly being negotiated, constantly 'in crisis'. I can refer to Ulrich Oevermann's interpretation of the philosophy of crisis as understood by Charles Sanders Pierce, which considers crisis and routine to be the two characteristic parts of human life (Oevermann 2001). Due to their sequential nature, the routinised and ritualised practices are being tested all the time; they are the subject of constant negotiations between different sides or actors. On the one hand, we need to ascertain who shapes the discourses and who recreates the practices. On the other hand, we should identify the structurations of general discourses in this event and the niches or shifts which were, and still are, characteristic of, and significant for, the participants themselves, but invisible to the spectators or the wider public. What is the relationship between the different discourses and how do they resonate with the public?

The question here is who may present themselves, who is included and who is excluded from the event? Who can take part in the game of self-presentation and help shape the identity? More specifically, on what level is it a question of both self-exclusion and the exclusion of the Other, or of self-inclusion and the inclusion of the Other? How and to what extent are these exclusions and self-inclusions an integral part of unsuccessful habituation procedures? Both the location of the ritual and the ritual itself can be problematic. If we build on 
Helge Gerndt's (1979) definition of participants and expand it, we can speak of leaders, organisers, participants, spectators, passers-by, the excluded, and those who either oppose or ignore the ritual.

Within this framework, the image of the event in Carinthia is highly differentiated. The German-speaking members of conservative parties, who see themselves as Carinthian patriots, attend commemorations organised by brambovci (Abwehrkämpferbund) and by such political parties as the one that Jörg Haider led. On the other side are Slovenians, the descendants of those who voted for Yugoslavia and of those who voted for Austria and then realised that the promises were false. They used to ignore the commemoration and kept themselves busy on that day, for example, with farmwork.

The events of 2010, however, have shown that this image is slowly changing; a few Slovenians, despite having great reservations, took part in the commemorative procession in Klagenfurt. A group from Bistrica even sang a Slovenian song in their local dialect in front of the representatives of the country, the state and the church. The image of the procession itself, and of its main participants, was different as well, because the Kärntner Heimatdienst (Carinthian Homeland Service) and its leader, Dr. Josef Feldner, were not invited to help organise the event, even though Dr. Feldner was by then already a member of the Consensus Group, along with Dr. Marjan Sturm, Dr. Stefan Karner, Heinz Stritzl and Bernard Sadovnik. ${ }^{4}$

\section{POSTER: SAME AND DIFFERENT}

As mentioned above, the majority of Carinthians, including a significant and critical number of Slovenes, voted for Austria. There were various reasons for their decision; some were concerned with the economy, others with various pressures - they were themed in different ways. The issue now is how this decision was explained and presented at the event itself, i.e., at the solemn commemoration in Klagenfurt. The programme, which was printed on a poster, listed the festivities and other events in a chronological order. In a way, it also represented a list of the participants who had the right and obligation to represent certain layers and interests of the local population. The poster contained two items worthy of note and discussion. On the right side was an address by the then Governor of Carinthia, Gerhard Dörfler, from the Alliance for the Future of Austria (Bündnis Zukunft Österreich - BZÖ), the successor of Dr. Jörg Haider, who had suffered a fatal accident just outside Klagenfurt. In his address the master of ceremonies, as Harald Wydra might call Mr. Dörfler 
(Wydra 2009), presented the official, political interpretation of the events that took place 90 years ago.

Carinthia celebrates the 90th anniversary of the Carinthian plebiscite under the motto "Yesterday - Today - Tomorrow". On the foundation of our shared history, we should create our future together. 90 years ago, the people of Carinthia unequivocally decided to stay unified and to live in a homeland within Austria. This commitment to the unity of Carinthia was not merely a victory of democracy - it was a decisive rejection of the prevailing nationalisms of the time, as Carinthian speakers of German, Slovene and Windisch languages voted together for a new Austria and against the Greater-Serbian State of SHS. ${ }^{5}$

The address touches on nearly all key issues, the problem and the image of the parade organised on the round anniversaries of the plebiscite. The address itself is incoherent, stretched between statehood, nation and ethnicity. The text contains still another element which furthers the division between Slovenes and Carinthians; the term Windisch is used to refer to the people who are 'inbetween', i.e., not German, but no longer Slovene either - people on the path to becoming German. Two strategies can be noted on the level of the address and the self-presentation of the Windisch (see windische.at). The first strategy is imposed by the dominant conservative discourse, which is propagated mainly by the Austrian Freedom Party and which aims to reduce the importance of the Slovene language environment and culture in Carinthia. This strategy is also used to disqualify the expectations and demands put forth by the prominent representatives of the Slovenian communities of both Carinthia and Slovenia. The second strategy is characteristic of numerous members of the Slovenian community, whose parents and grandparents spoke a Slovenian dialect but never attended school in Slovenian and were therefore unable to write in this language. The most convincing example of this particular identification was presented by Bertl Petrei, an ethnographer and ethnologist, who wrote about it in his autobiography called Kokolore (Petrei 1986) and in an online forum on windische.at (Petrei 1995). Petrei sees the Windisch as a question of cultural rather than ethnic self-identification and self-presentation. The pervasiveness of the perception of the Windisch as that of a special form of belonging and the sense of language (in)competence are both indicated in the statement made by the intellectual who is known in museum circles: he uses the term 'Windisch' to refer to people who speak a form of the Slovenian language, but who cannot write in it. Of particular interest is another element of the poster - an element that refers to the democratic nature of decision-making and to the fight against nationalisms. In using the syntagmas 'victory of democracy' and 'rejection of 
nationalisms', the State Governor is relying on the discourses and dichotomies of today. By using the syntagma 'Greater-Serbian State', however, he is creating an image of the Other, of the greater Serbia, of a culture that is unacceptable, undemocratic, and associated with nationalism. This is an image represented by a Serbian soldier in an exhibit at the Regional Museum of Carinthia: a soldier that wants to seize the entire territory of Carinthia. The State Governor used the discourses of today to create a discordance that makes it possible to overlook the nationalisms that resulted in the intensive Germanisation of Carinthia in the 19 th and 20 th centuries.

The relationships between the communities and languages in Carinthia can be discerned from the left side of the poster as well. ${ }^{6}$

\section{October 8}

1:00 pm Session of the Carinthian Parliament in the Great Hall of Arms in the State Parliament Building

3:00 pm Ceremony marking the anniversary in the Great Hall of Arms in the State Parliament Building with speeches by the president of Austria, the federal chancellor, and the state governor, performances by two youth choirs (German and Slovenian), and participation of the Slovenian ethnic community (ORF live broadcast)

\section{October 9}

9:30 am Plebiscite commemoration at the cenotaph in the military cemetery in Annabichl

11:00 am October 10 celebration of the State of Carinthia in the courtyard of the State Parliament Building, in front of the Carinthian Unity memorial

2:00 pm Wreath-laying ceremony at the graves of Governor Arthur Lemisch (Holy Trinity Church in Sankt Veit an der Glan), Martin Wutte (Obermühlbach, near Sankt Veit an der Glan), and Lieutenant Colonel Ludwig Hülgerth (Rottenstein mansion)

Of particular interest is the representation of the non-German Carinthians who chose to vote for Austria and who made the 2010 celebration of the plebiscite possible.

Non-German voters were presented and included in the programme twice: once in an event organised by the Church and the Bishop of Klagenfurt on October 2, and again on October 8, two days before the anniversary, when prominent individuals and invited guests gather in the Wappensaal or the Armorial Hall. They are listed Einbindung der slow. Volksgruppe (Inclusion 
of the Sln. ethnic community). Before we analyse how the Slovenian ethnic community was included in the programme and who was chosen to represent it, we need to consider the definition as it was expressed and published in the official self-presentation of the State and of the State Governor, and as it was conveyed in the programme of the commemoration. If the official poster shows a fairly visible and obvious political practice and if it sets and simultaneously reflects the dominant political discourse, to what extent is the Slovene ethnic community presented on the poster? What does 'Inclusion of the Sln. ethnic community' mean? Does it mean that politicians did not know who would represent this community and how they would represent it? Does it mean that the speaker was to be appointed or chosen at the last moment? Or that they were to be chosen by a proponent of the ruling discourse in order to achieve a desired effect? Or was the community so divided that it did not have a genuine, unanimously chosen representative? An analysis of the poster and a comparison with other participants show that everyone except the Slovenian ethnic community had appointed speakers and chosen a set form of self-presentation. The representative of the Slovenian ethnic community could have been announced without mentioning any names as well, in the same manner in which the President, the Chancellor, and the State Governor were announced. The actual (and possibly unintentional or undesired) result of using 'Einbindung der slow. Volksgruppe' with the abbreviation of slowenischen into slow. is an anonymising strategy, and a practice in which the one responsible for the dominant discourse is also the orchestrator of the event. In this case, the event was organised by the state government, the Governor, who simultaneously granted the minority the right to express themselves and limited or reduced the recognition of that same minority into a meticulously planned chronotope, which prescribed how, where, and for how long the minority was allowed to present itself within the framework of the official ritual practice.

The 'inclusion of the Sln. ethnic community' happened with the participation of Dr. Valentin Inzko, the chairman of the National Council of Carinthian Slovenes, who was also the European Union Special Representative for Bosnia and Herzegovina at the time, and the first person in fifteen years to speak Slovenian in the Carinthian Armorial Hall. In 1995, his father had given a speech in the same hall. What happened with Dr. Inzko's speech? The diplomat Dr. Valentin Inzko, the most prominent Slovenian speaker at the time, seized the opportunity presented to him by Dr. Marjan Sturm, who allowed him to speak in his stead, and turned what was to be a brief and marginal self-presentation of the Slovenian community, i.e., a five to seven minute speech representing five to seven percent of the duration of the commemorative session, into a 45 minute speech. ${ }^{7}$ He gave one of the most thorough summaries of the history of Slo- 
venes and Germans in Carinthia. The underlying message was that it was the Slovenian community that contributed to an undivided and united Carinthia. He included a vision of a Carinthia where both ethnic communities would live together in mutual respect for one another and offer their youth a secure future. Discussions with conservative Carinthian intellectuals revealed that Dr. Inzko broke the agreement and the rule of the self-limiting perspective common in Slovenian self-presentations. He went far outside the limits of the chronotope prescribed for the Slovenian community by the dominant discourse.

The use of the two languages in posters, advertisements, and other materials also speaks to the relationships that are in play in the plebiscite commemoration. According to available data, Slovenian was used in only two instances: in Dr. Inzko's address (2010) and in the case of the villages that presented themselves in both languages. All other materials financed by the state government, for instance, the official poster, advertisements, etc., were published in German.

The official speeches given at the event, at the commemorative parade, also presented an opportunity for using Slovenian. However, not a single Slovenian speaker was included - all speeches were given in German. The only one who dared open the space to the second language in Carinthia was the Austrian President, Dr. Heinz Fischer, who spoke three sentences in German and followed up with an approximate Slovenian translation. This was an official greeting, an address, which contextualised the event and indicated that there exist two language communities in Carinthia. The second part of his address had to do with the central point of contention in Carinthia at the time, i.e., bilingual signs. He concluded by expressing a wish for a good and peaceful future:

Werte Festgäste! Liebe Kärntnerinnen und Kärntner!

Cenjeni Častni Gosti! Drage Korošice in Korošci! [---]

"Die Zeit ist reif". (Čas je zrel) habe ich schon im Juli in meiner Antrittsrede als wiedergewählter Bundespräsident gesagt. ${ }^{8}$

Ich wünsche dem Bundesland Kärnten und allen Menschen, die hier ihr Zuhause haben, eine gute und friedliche Zukunft.

Deželi Koroški želim dobro in mirno prihodnost.

Honoured guests! Dear Carinthians! [---]

"The time is ripe," is what I said back in July in my inaugural speech as re-elected president.

I wish the State of Carinthia and all the people who make their home here a good and peaceful future.

I wish a good and peaceful future for Carinthia. 
The sentence that was the most important and also the most often quoted, both after the President's re-election and today, at the commemoration of the plebiscite, was: The time is ripe.

The above statement opens and expresses two levels on which the reality of the ethnic group can be approached within ritual practice. The ethnic group, the minority (Minderheit), is defined as an important problem or issue; it stresses the use of both languages on the place-name signs which are relevant for the minority. The utterance 'The time is ripe', however, does not refer to a comprehensive solution of the question of the minority; it only addresses a part, a particularity. At the same time, this statement functions on another level, on the level of the Austrian state: within the horizon of the discourse conveyed by the President, bilingual signs are a solution of totality, i.e., a solution of the Austrian state contract. According to the official Austrian-Viennese discourse, the signs would fulfil the most critical and, as Stefan Karner puts it, the loosely defined Article 7 of the contract, on the basis of which the Austrian state was constituted. This would also prevent actions such as the one in which Rudi Vouk placed the minority in the centre of the discourses in Carinthia and made topographical signs the focal point of the issue concerned with the minority.

Since these were the only official words spoken in Slovenian on October 10, 2010 , they accentuated the speech by pointing out one of the most pressing matters in Carinthia. In this very thought-out and, given the situation in Carinthia, relatively balanced speech, the President imagines what the 2020 commemoration of the plebiscite should look like, with Austrians and Slovenians celebrating the centennial together. At the same time, Dr. Fischer simplifies and sets boundaries for the discourse about the position of Slovenians and of the Slovenian community in Carinthia. In his speech, every aspect of Article 7 of the Austrian contract, which addresses the rights of the Slovenian community in Carinthia and the obligations and commitments of the Austrian state, is reduced to the single issue of bilingual signs.

These few words in Slovenian also point to the ambivalences related to the issues in Carinthia, which are characteristic of the perception and reception of the Slovenian ethnic community; they concern not only the relationship between a particular solution and a comprehensive solution, but also the constituting of 'majority' and 'minority' perspectives.

The interplay between local/regional, national, and media discourses, as well as the majority perspective, became apparent, for example, during a TV show about bilingual signs, ${ }^{9}$ in which only one of the six guests who spoke about the Slovenian ethnic minority was a Slovenian. Valentin Inzko was the only one to present a viewpoint that demanded a more thorough recognition of the 
Slovenian ethnic minority, which would include bilingual signs. In addition to the other five guests, he also faced the general Austrian auditorium, in which representatives of the Austrian state step up with the demands of the local authorities. In a position such as the one Dr. Inzko found himself, it is next to impossible to avoid becoming a scapegoat, since any position that differs from the dominant one is predestined to be condemned or characterised as troublemaking.

The next problem, which can be gathered from discussions with Dr. Josef Feldner and with intellectuals and historians from various Carinthian state institutions, concerns the oft expressed opinion of how generous the German majority is, and should be, towards the Slovenian minority. The most defined viewpoint is held by Feldner, and he expresses it within the Consensus Group: "With our 97 percent majority, we can afford to be generous without clinging to every letter of the law." 10 On the one hand, Feldner's generosity is an expression of the nearly 100 percent majority; on the other hand, it is based on the expectation that Slovenia will also show generosity and recognise the fundamental rights of its own indigenous German population. ${ }^{11}$

Josef Feldner said in an interview ${ }^{12}$, and once more on television, that Kärntner Heimatdienst had more members than there were declared Slovenians, so there was nothing to fear. ${ }^{13}$ This 'generous' standpoint confirms the regional hierarchical and ethnic structurations and says much about the distribution of power, about who rules the region, and who decides what a member of the minority can or cannot do.

Valentin Inzko's speech, the bilingual place-names on the self-presentational signs of some Carinthian settlements, and the words spoken by the Austrian president, implicitly opened a niche among the established images of the manifestation of belonging to Carinthia and Austria, and offered opportunities for different practices in the political celebration of the ritual.

These opportunities and the need for a different commemoration were addressed in 2010 by the participants themselves, when they criticised the poor organisation of the event, inadequate provisions, and the long wait times. Andrea Bergmann addressed these organisational issues in an article published in the most prominent Carinthian newspaper, Kleine Zeitung. She asked the main organiser, Horst Moser, whether it made sense to organise the parade at all, given that only a few thousand people came to watch it. ${ }^{14}$ Criticism that was far more direct was written by those who actually participated in the parade, albeit anonymously, in the comment section of Bergmann's article. 


\section{IMAGES OF OPPOSITION: FROM DEMONSTRATIONS TO COMMEMORATIONS}

The concepts and practices presented at the commemoration of the Carinthian plebiscite, and especially the rituals performed by the members of the Ulrichsberg Burschenschaft (student fraternity), are controversial for the members of smaller, alternative groups, which have, in recent years, gathered mainly around the concepts of Aufklaeren (clarifying) and Erinnern (remembering). Different practices have become established in this context.

One of them is directly related to the commemoration of the plebiscite and is centred in Klagenfurt: in 2010, on the eve of the main parade, a demonstration was organised in Klagenfurt by the group ANTIFA, mainly by young people. They protested against the nationalistic German character of the plebiscite commemoration, which ignores the Other, the Different, and excludes not only Slovenians but also immigrants.

Other practices are mainly connected with remembering the victims of Nazi and fascist violence, both at the Ljubelj (Loibl) concentration camp and in Klagenfurt. These practices were neither encouraged nor organised by local or national governments. The incentives came from individuals, for instance, Dr. Peter Gstettner, Franc Wakounig, Hans Haider (in Beljak/Villach), and from their societies. Commemoration ceremonies for those who died at the Ljubelj camp, which was part of Mauthausen, are also attended by the survivors of the camp, first on the Austrian side of the border and then on the Slovenian side.

A different practice, the scenario and the choreography of which are based on ritual, is the so-called Schweigemarsch or Gedenk-Gehen ${ }^{15}$ - the Memorial Walk. It has been organised every year, in the last week of April, since 2008. The march commemorates the victims of the anti-fascist, anti-Nazi struggle, in the years between 1941 and 1945. Special courts, usually presided over by the 'bloody' judge Dr. Roland Freisler (Baum 2011), condemned victims to death by hanging or by decapitation. The verdicts were still being carried out in the last months before the end of the war. A disproportionately large number of women who were sentenced and the examples of the nature of their executions should be noted. At the last trial alone, which took place in January 1945, six men were hanged and five women decapitated.

The ritual practice first suggested by Franc Wakounig and started by the society Memorial Kärnten/Koroška defines a new content every year (a commemorative plaque bearing the names of the fallen members of the anti-Nazi movement was unveiled in front of the courthouse in 2013), and always has some basic characteristics, for example, a march, speeches, the presence of a priest, 
etc. This ritual practice is also important and interesting because it expresses a certain attitude towards the Slovenian ethnic minority, since nearly all victims of the Nazi aggression or regime were members of the Slovenian community.

In its first year, 2008, in the time of Jörg Haider, this practice was controversial. The organisers had to obtain a special dispensation from the local government, which was not granted until they threatened to involve the media. ${ }^{16}$ In 2011, when I examined the practice, it was mentioned both in the Carinthian newspaper Kleine Zeitung and on the Austrian national television network ÖRF. Among those who spoke at the site of the former Gestapo headquarters, from where prisoners were taken to the courthouse and into their deaths, was the then (second) Vice-Governor of Carinthia, Dr. Peter Kaiser, who was also the representative of the Social Democratic Party of Austria in the Carinthian Landtag.

This ritual practice did not gain an official status until 2013, which corresponded with the March elections and changes in the Carinthian government. At this time, the right-wing parties, particularly the Freedom Party, lost their primacy, mainly due to the Hypo Bank affair (see Economist 2010) and other scandals. This also changed the attitude towards the two languages on a symbolic level. When Dr. Peter Kaiser was elected State Governor, he spoke in Slovenian, decisively and frequently, and a representative of the Slovenian ethnic community spoke in both languages as well.

Dr. Bernd Lutschounig, a judge in Klagenfurt, and chief prosecutor Dr. Mirko Borotschnik, took the floor at the 2013 commemoration, and Franc Wakounig spoke about the past aggression against the Slovenian community and against all opponents of Nazism. The fact that the commemorative plaque was cosponsored by the Office of State Secretary Wolfgang Waldner, speaks to a type of an official recognition and clearing up of the past.

These types of ritual practices can be understood as fresh attempts, similar to the ones organised by the Concordia et Pax group in the Gorica/Gorizia region (cf. Fikfak 2009), by the Erinnern group in Beljak/Villach ${ }^{17}$, or by the Aktionskomitee Mauthausen group. The latter and Dr. Peter Gstettner are the organisers of a similar programme, a commemoration of those who were sent to concentration camps on the Austrian side of Ljubelj. This gathering is a ritual by itself. Its content is commemorative, the remembrance of the dead, the condemned, the victims from the groups that said no to Nazism and to violence against those who were different. The spectators and the participants themselves are affected, since they involve survivors of the camps, and the children and other relatives of the victims. Next to them stand those who support diversity and self-reflection of the past. 
In media discourses, these ritual practices are still considered to be marginal. The Austrian state television network lists them among reports about the minority, so they are not considered on the same level as events that concern the entire State of Carinthia. In the same vein, the Carinthian Kleine Zeitung published an announcement on April 25 of an event that was due on April 29, yet did not comment on the event on April 30, the day after it had taken place. The only noteworthy response that the event evoked in Slovenia was an exhaustive news report by Boris Jaušovec (2013) in the daily newspaper Večer.

It can be said that the production, reception, and perception of this ritual practice have been changing. It is obvious from the responses in the general public that the Gedenk-Gehen or Memorial Walk is becoming one of the most typical ritual practices in Klagenfurt. By attracting several parties, but mainly due to its placement within a broader context of reflecting on Nazi-fascist aggression and the role of Austria in that aggression, the Memorial Walk reaches beyond the horizon of the Slovenian ethnic community. An analysis of ritual practices shows that change is an integral part of discourses which are (influenced by the ruling structures on the level of the regional government, the constitutional court, and the country) increasingly using self-reflection to influence the changes in perception.

The stories about ritual practices are stories about ritualisation, constant negotiation, sequencing, and routine in crisis, the opening of new spaces for decisions, new shifts, and turns.

Thus, in 2009, the military and the Minister of Defence, Norbert Darabos, decided to distance themselves from the memorial gathering that takes place on the Ulrichsberg Mountain. ${ }^{18}$ Another example of a shift in perspective can be found in the case of the Kärntner Heimatdienst, under the leadership of Josef Feldner. The Heimatdienst changed its stance on defending Germanhood and was involved in the process of creating a consensus between both language groups. The change is also highlighted by the participation of four settlements with bilingual signs in the procession in Klagenfurt. Their decision clearly points to an altered understanding of ethnicity as a different self-concept and self-presentation of the Slovenian community. 


\section{NEGOTIATIONS AND (RE)INTERPRETATIONS}

It can be said about both ritual practices that they are in motion and in crisis. In the case of the October commemorative parade in the streets of Klagenfurt, it has become less clear who the event is supposed to address. Who or what is embodied by the members of the groups who march in the parade? Who are they addressing, who is included in it and who is still excluded? The decline in the number of spectators indicates that interest is waning and that the event has become less important. It is no longer as constitutive for the image of the land as it was more than twenty years ago, when the large country called Yugoslavia peeked over the Karavanke Mountains.

The other ritual practice is also in the process of change, not only with the image and the ritualisation that are being formed, but also with the relatively slow progression of its establishment in the discourses on the local and national levels. Commemoration of the victims, be it in Klagenfurt or at the site of the Ljubelj concentration camp, reinforces the need for reflecting on the role that Austrians played in the Nazi prosecution of the Others and the Different.

We can see changes, constant negotiations and re-interpretations of the meaning of the ritual practices. There is the desire of, for example, historians at the Carinthian State Museum, to prepare an exhibition about the plebiscite, in cooperation with their Slovenian colleagues, and there was the speech given by the Austrian President Heinz Fischer. Most importantly, there was the speech given by Valentin Inzko, in which he shifted focus from the syntagma "indivisible and united Carinthia" to "Carinthia with another, with a neighbour". All of these are the latest acts and ritual practices that create a space for different discourses that would enable different politics of commemorating.

In this context, a commemoration was held in Velikovec (Völkermarkt) for all fallen defenders, "for those who fought for the northern Slovenian border, and for the Carinthians who fought for the unity of Carinthia". ${ }^{19}$

The changes in the ranks of the holders of state power were especially important for the altering of the perception and production of the ritual. New and different elements of the official discourse began to be emphasised. State Governor Dr. Peter Kaiser wore a casual or 'business' suit instead of a traditional costume in the local colour when he spoke at a monument in the Annabichl cemetery, on the anniversary of the plebiscite in October 2013. He also said a few words in the Slovenian language, and the official poster bore the following motto, printed in both languages and in letters of the same size:

Zukunft gestalten; Vergangenheit verstehen.

Prihodnost oblikovati; preteklost razumeti.

To shape the future; to understand the past. 


\section{NOTES}

1 Foibe are chasms or caves, common in the Kras (Carso) region, a karstic plateau region shared by Italy, Slovenia, and Croatia. They were used as open-air cemeteries especially in 1943 and 1945. Many books and papers have been written about the foibe and foibe massacres; different interpretations are offered and estimates of victims vary according to the viewpoint of the author (cf. Slovene-Italian Relations 2000; Pupo \& Spazzali 2003; Cernigoi 2005; Pirjevec 2009).

2 See http://ec.europa.eu/archives/publications/booklets/eu_documentation/04/txt_en.pdf, last accessed on December 17, 2014.

3 The Slovenian Press Agency reported that the National Council of Carinthian Slovenes (NSKS) was not invited to participate in the organisation of the ceremonies; in addressing the Landtag of Carinthia, the NSKS President Valentin Inzko expressed the hope that Carinthia would become forward-looking and show more support for its Slovenian minority (http://www.sta.si/en/vest.php?s=a\&id=1556191, last accessed on December 17, 2014).

${ }^{4}$ Members of the Consensus Group endeavour to establish a dialogue between different groups in Carinthia, particularly between Slovenian and German language communities. The group received several Austrian and European awards for its efforts (http://www. kleinezeitung.at/kaernten/3104293/vierte-auszeichnung-fuer-konsensgruppe.story, last accessed on December 17, 2014).

5 Original text: Kärnten begeht das stolze Jubiläum "90 Jahre Volksabstimmung” unter dem Motto "Gestern - Heute - Morgen". Auf dem Fundament der gemeinsamen Geschichte gilt es, gemeinsam die Zukunft zu gestalten. Vor 90 Jahren hat die Kärntner Bevölkerung eine klare Entscheidung für den ungeteilten Verbleib ihrer Heimat bei Österreich getroffen. Das Bekenntnis zur Einheit Kärntens war nicht nur ein Sieg der Demokratie, sondern auch eine klare Absage an den damals in Europa vorherrschenden Nationalismus, weil deutsch- und slowenischsprachige ebenso wie windische Kärntner gemeinsam für das neue Österreich und gegen den großserbischen SHS-Staat stimmten.

6 Original text:

\section{Oktober}

13.00 Uhr Festsitzung des Kärntner Landtages im Großen Wappensaal des Landhauses

15.00 Uhr Festakt zum Jubiläum im Großen Wappensaal des Landhauses mit Reden des Herrn Bundespräsidenten, des Herrn Bundeskanzlers und des Herrn Landeshauptmannes, musikalische Umrahmung durch zwei Jugendchöre (deutsch und slow.), Einbindung der slow. Volksgruppe (ORF-Direktübertragung)

\section{Oktober}

9.30 Uhr Abstimmungsgedenkfeier beim Ehrenmal auf dem Soldatenfriedhof in Annabichl

11.00 Uhr 10.-Oktober-Feier des Landes Kärnten im Landhaushof - Stätte der Kärntner Einheit

14.00 Uhr Kranzniederlegungen an den Gräbern von Landesverweser Dr. Arthur Lemisch (Dreifaltigkeit bei St. Veit/Glan), Dr. Martin Wutte (Obermühlbach bei St. Veit/Glan) und Obstlt. Ludwig Hülgerth (Schloss Rottenstein). 
7 The speech is available in both Slovenian and German at http://issuu.com/nedelja/docs/ inzko (last accessed on December 17, 2014). For a report on the speech see Festlicher Auftakt im Jubiläumsreigen. Klagenfurt, ÖRF, October 8, 2010, at http://ktnv1.orf. at/stories/474845 (last accessed on December 17, 2014).

8 Dr. Fisher's inaugural speech was covered, for example, by the Kleine Zeitung on July 8, 2010 (available at http://www.bundespraesident.at/newsdetail/artikel/redevon-bundespraesident-heinz-fischer-in-klagenfurt-anlaesslich-90-jahre-kaerntnervolksabstimm/, last accessed on March 20, 2015).

9 In the TV show Im Zentrum on ORF2, on April 10, 2011, the host Ingrid Thurner discussed topographical signs with Dr. Josef Ostermayer, State Secretary in the Federal Chancellery of Austria, Gerhard Dörfler, the Governor of Carinthia, Valentin Inzko, Chairperson of the National Council of Carinthian Slovenians, Josef Feldner, leader of the Kärntner Heimatdienst, and Antonia Gössinger, a journalist with the Kleine Zeitung (http://www.be24.at/blog/entry/657253, last accessed on December 23, 2014). It is interesting how the reporters mentioned the doctoral title held by Ostermayer, yet omitted the titles held by Inzko and Feldner.

${ }^{10}$ Original text: Mit unserer 97\%igen Mehrheit können wir es uns leisten, großzügig $z u$ sein und nicht kleinlich auf dem Buchstaben des Gesetzes zu kleben. Statement Informations- und Diskussionsveranstaltung. St. Michael ob Bleiburg/Šmihel nad Pliberkom, 22. Juli 2010 von Josef Feldner, Obmann Kärntner Heimatdienst (http:// www.zeitdokument.at/ztdok/b_txzz02.html, last accessed on January 5, 2015).

${ }^{11}$ Original text: Bei Großzügigkeit gegenüber unserer kleinen slowenischen Volksgruppe dürfen wir umso berechtigter auch vom Nachbarstaat Slowenien Großzügigkeit erwarten gegenüber der heute nur mehr wenige Tausend Personen umfassenden autochthonen deutschen Volksgruppe und die endliche Zuerkennung von Basisrechten verlangen (http://www.zeitdokument.at/ztdok/b_txzz02.html, last accessed on January 5, 2015).

12 Conversations with prominent representatives of Carinthian politics in English and German (Dr. Rudi Vouk, Dr. Josef Feldner, Dr. Klaus Ottomeyer) were gathered by myself and by Dr. Thomas Wolfe from the University of Minnesota (USA).

${ }^{13}$ Estimates about the size of the Heimatdienst vary; even Feldner mentions numbers between 15,000 and 20,000. We can draw some conclusions based on the number of ballot papers (5000) used when Josef Feldner was re-elected President, as stated next to a photo in Kleine Zeitung on 14 September 2012: 100 members and 10,000 supporters (http://tinyurl.com/ny7xheo, last accessed on March 23, 2015).

${ }^{14}$ Andrea Bergmann asked: "Ob es in Anbetracht der wenigen tausend Zuschauer entlang der Umzugsstrecke überhaupt noch einen Festumzug geben soll?” Horst Moser answered with: "Das entscheidet die Politik." (http://www.kleinezeitung.at/kaernten/ volksabstimmung/2513597/zorn-kritik-nach-dem-festumzug.story\#forummain, last accessed on January 5, 2015).

${ }^{15}$ Different names are in use. The most recent one, from 2013, is Gedenk-Gehen or Memorial Walk (as named by Franc Wakounig).

${ }^{16}$ Information provided by Franc Wakounig. 
${ }^{17}$ Hans Haider presents the group in more detail at http://www.net4you.com/haiderftp/ ueber/index.html (last accessed on January 5, 2015).

${ }^{18}$ See http://www.presseurop.eu/en/content/news-brief/84821-ach-no-more-ss-tributes, last accessed on January 5, 2015.

${ }^{19}$ Marjan Sturm wrote about this in one of his columns called Marjanizmi (Marjanisms), which was published on October 11, 2013, and is available at http://www.slo.at/zso/ sturm_sl_more.php?id=1746_0_6_0_m (last accessed on January 5, 2015):

The politics of dialogue and cooperation pays off

Two important events were organised recently: Feldner and I initiated a memorial commemoration for the fallen in Velikovec: for those who fought for the northern Slovenian border, and for the Carinthians who fought for the unity of Carinthia. "They died believing in their homeland", was the motto of the commemoration. This was an exceptionally humane and reverent message, which had never before been heard in Carinthia. Feldner also pointed out that all the victims of National Socialism in the country needed to be considered as well.

We also invited the Ljubljana General Maister Society, which was not even aware of the existence of the cemetery in Velikovec and which, because of whispers coming from Klagenfurt, did not attend the commemoration. That is not what a humane and reverent way of treating your own fallen is supposed to look like.

The commemoration of the plebiscite was a bit different than usual this year. Slovenians were welcome, our language could be heard, and the celebration was considerate and reverent. The youth and the state governor were allowed to take center stage. Feldner and I answered the moderator's questions as to why we started the politics of dialogue in the country. Afterwards, people would stop me in the street and congratulate me on my politics. A lot has changed and I am a bit proud of the part that I played in that.

\section{REFERENCES}

Austin, John L. 1962. How to Do Things with Words: The William James Lectures Delivered at Harvard University in 1955. Edited by J. O. Urmson. Oxford: Clarendon Press. Available at http://www.dwrl.utexas.edu/ davis/crs/rhe321/ Austin-How-To-Do-Things.pdf, last accessed on January 7, 2015.

Baum, Wilhelm 2011. Die Freisler-Prozesse in Kärnten: Zeugnisse des Widerstandes gegen das NS-Regime in Österreich. Klagenfurt: Kitab.

Burz, Ulfried \& Pohl, Heinz-Dieter (eds.) 2005. Politische Festtagskultur in Kärnten: Einheit ohne Einigkeit? Kärnten und die nationale Frage, Vol. 3. Klagenfurt: J. Heyn.

Cernigoi, Claudia 2005. Operazione "Foibe": Tra storia e mito. Udine: Resistenza storica Kappa vu.

Economist $2010=$ The Austrian Bank at the Centre of a Growing Web of Scandal. The Economist, September 9. Available at http://www.economist.com/node/16996984, last accessed on March 23, 2015. 
Fikfak, Jurij 2009. Cultural and Social Representations on the Border: From Disagreement to Coexistence. Human Affairs, Vol. 19, No. 4, pp. 350-362. http:// dx.doi.org/10.2478/v10023-009-0049-1.

Gerndt, Helge 1979. Gedanken zum Festwesen der Gegenwart. Traditiones, Vol. 5-6, pp. 153-161.

Hayek, Friedrich August 1960. The Constitution of Liberty. Chicago, IL: University of Chicago Press.

Inzko, Valentin 2010. Das gemeinsame Kärnten: Skupna Koroška. Rede anlässlich des 90. Jahrestages der kärntner Volksabstimmung im grossen Wappensaal des Landhauses zu Klagenfurt / Govor ob 90. Obletnici plebiscita v Veliki dvorani grbov v deželnem dvorcu v Celovcu. Klagenfurt/Celovec, 8. 10. 2010. Available at http://www.skupnost.at/wp-content/uploads/govor_dr_inzko_sc.pdf, last accessed on January 7, 2015.

Jaušovec, Boris 2013. Za nacizem so bile žrtve preveč človeške. Večer, April 29. Available at http://ris.vecer.com/arhivi/arhiv.aspx, last accessed on March 23, 2015.

Lukes, Steven 1975. Political Ritual and Social Integration. Sociology, Vol. 9, No. 2, pp. 289-308. http://dx.doi.org/10.1177/003803857500900205.

Moritsch, Andreas 2002. Sozialwirtschaftliche Voraussetzungen der Entwicklung zum 10. Oktober 1920 in Kärnten. In: Valentin Hellwig \& Susanne Haiden \& Barbara Maier (eds.) Die Kärntner Volksabstimmung 1920 und die Geschichtsforschung. Klagenfurt: Heyn, pp. 221-224 (German); pp. 348-349 (Slovenian).

North, Douglass C. 1991. Institutions. Journal of Economic Perspectives, Vol. 5, No. 1, pp. 97-112. http://dx.doi.org/10.1257/jep.5.1.97.

Oevermann, Ulrich 2001. Die Philosophie von Charles Sanders Peirce als Philosophie der Krise. In: Hans-Josef Wagner (ed.) Objektive Hermeneutik und Bildung des Subjekts. Göttingen: Velbrück Wissenschaft, pp. 209-246.

Petrei, Bertl 1986. Der Kokolore: Menschen und Geschichten einer Kindheit. Klagenfurt: Heyn Verlag.

Petrei, Bertl 1995. DAS WINDISCHE - ein letzter Versuch. Aus: Die Kärntner Landsmannschaft. Available at http://www.windische.at/AKADEMIE_FI/ GESCHICHTE/AK_GE_Petrei.htm, last accessed on January 7, 2015.

Pirjevec, Jože 2009. Foibe Una storia d'Italia. Torino: Giulio Einaudi Editore.

Pupo, Raoul \& Spazzali, Roberto 2003. Foibe. Milano: Bruno Mondadori.

Slovene-Italian Relations 2000 = Slovene-Italian Relations $1880-1956$ by the SloveneItalian Historical and Cultural Commission. Koper-Capodistria, July 25. Available at http://www.theslovenian.com/articles/sihcc.htm, last accessed on March 23, 2015 .

Valentin, Hellwig 2006. Die Entwicklung der nationalen Frage in Kärnten 1918-1945/ Razvoj nacionalnega vprašanja na Koroškem 1918-1945. In: Hellwig Valentin \& Peter Karpf \& Udo Puschnig (eds.) Der Staatsvertrag von Wien 1955-2005: Die Kärntner Perspektiven. Kärnten Dokumentation, Band 22. Klagenfurt: Amt der Kärntner Landesregierung, pp. 31-88. Available at http://www.volksgruppenbuero. at/images/uploads/band22_final_sc.pdf, last accessed on January 7, 2015. 
Wydra, Harald 2009. The Liminal Origins of Democracy. International Political Anthropology, Vol. 2, No. 1, pp. 91-109. Available at http://www.international. politicalanthropology.org/images/articles/2009_1/ipa_journal_1_2009_wydra.pdf, last accessed on January 7, 2015.

Zinkner, Martin Alois 2009. Analyse des Kärntner Ortstafelkonfliktes: Gesetze, Akteure und Möglichkeiten. Diplomarbeit. Wien: Universität Wien. Available at textfeld. ac.at/pdf/1667.pdf, last accessed on March 23, 2015. 


\title{
POLITICISING ST. MARTIN AND CONSTRUCTING HERITAGE: A CASE STUDY OF A SMALL TOWN IN CROATIA
}

\author{
Juraj Belaj, Marijana Belaj, Petra Kelemen, Filomena Sirovica
}

\begin{abstract}
The article focuses on the processes of constructing and interpreting heritage and their use in legitimising ideological aims and creating a desired cultural identity of the town. Based on ethnographic records and accounts, newspaper and Internet sources, as well as recent archaeological investigations, the authors trace the positions attributed to St. Martin in the public (re)signifying of Dugo Selo, a small town in Croatia. They present St. Martin's gradual evolution from a saint on the margin of Communism through a local symbol associated with a broader national framework, towards a symbol of the pro-European orientation of the local community in the period when Croatia was politically approaching the European Union.
\end{abstract}

Keywords: construction, Croatia, Dugo Selo, heritage, politicisation, selection, St. Martin

\section{INTRODUCTION}

Based on the example of the use of St. Martin in Dugo Selo, a small town in northwestern Croatia, we trace the dynamics of the construction and interpretation of heritage aimed at creating a desired local identity. We observe these processes through three main sequences of the town's recent history, marked by political turbulence and changes in political orientation: through the period of the rule of Communist ideology, the period of gaining Croatia's independence, and the period marked by Croatia's preparations to join the European Union. The paper is based on the available ethnographic archival records covering the 20th century, newspaper records from the mid-20th century to the present, Internet resources, recent archaeological investigations, observations of contemporary public celebrations of St. Martin's Day, as well as interviews. In considering the positions attributed to St. Martin in the public (re)signifying of Dugo Selo, we are interested in the politics and selectivity of heritage. We consider the constructedness and processuality of the heritage and its embeddedness in 
a broader social and political environment to be incontrovertible. We therefore position ourselves alongside a number of research studies that, denying any naturalness, objectivity and self-evidence whatsoever of heritage and the identity built upon it, take interest in the agents performing the selection and search for contextual moments that foster the suppression and silencing of certain elements of culture, or their underscoring and transformation into a support pillar of local distinction and desired (tourist) attraction (see, e.g., Bendix 1989; Bruner 2005 [2004]; Hameršak \& Pleše \& Vukušić 2013; Handler \& Linnekin 1984; Kirshenblatt-Gimblett 1998; Timothy 2011). Following in those footsteps, we trace the way in which St. Martin has been treated in the public sphere of Dugo Selo: how his position at the margins of public imagery during the latter half of the 20th century shifted over the past twenty or so years to that of a prominent local symbol associated with a broader national framework and, lastly, what role he was awarded in the networking into European cultural landscapes during the period in which Croatia was drawing closer politically to the European Union.

\section{SETTING THE SCENE: DUGO SELO AND ST. MARTIN}

Dugo Selo is a small town lying some twenty kilometres east of Zagreb, gathering settlements at the foot of the hill called Martin Breg (206 m asl). The present population of the town numbers a little above ten thousand. The earliest written record about life in this area comes from the 1209 charter by Andrew II Arpad, King of Hungary and Croatia, which mentions the Land of St. Martin (“...terram sancti Martini...”), bestowed by the king upon the Order of the Knights Templar.

The rise of the administrative significance of Dugo Selo began in the mid-19th century when it became a district centre. In 1955, it gained municipal status, which it preserved throughout the next forty years, marked by Communist rule. In 1997, six years after Croatia had gained independence, its status was changed into that of a town.

Although St. Martin was the patron saint of the town from times immemorial, it was only in the last quarter of the 20th century that he became the lynchpin for the creation of the town's desired cultural identity. Apart from the town patronage, St. Martin is also the titular saint of a decrepit local church on Martin Breg, a hill above Dugo Selo, and by succession also the recent parish church in the centre of Dugo Selo.

The Roman Catholic parish of Dugo Selo is one of the five parishes in the City of Zagreb and the Zagreb County, and one of the 46 in Croatia that are 
dedicated to St. Martin the Bishop. St. Martin the Bishop, that is, St. Martin of Tours (Sanctus Martinus Turonensis) is considered the first saint worshipped in the western Christian tradition that did not die a martyr's death. He is one of the most popular saints in the West, recognised as the patron saint of France, of soldiers, horsemen and horses, smiths, weavers, tailors, winegrowers, shepherds, coopers, landlords, paupers, beggars, convicts, travellers, hoteliers, as well as domestic animals, geese in particular. In spite of the historical, geographical and cultural diversity of Croatia, the steadfast and rich veneration of this saint throughout the country is evident from the abundant hagiotopographic data, numerous ruins of earlier sanctuaries and the many older or younger churches dedicated to this saint, the literary heritage of St. Martin, as well as the celebration of his feast, Martinmas, the so-called Martinje (Zaradija Kiš 2004: 15-16). In Croatian popular piety, St. Martin is mostly associated with viticulture and wine. The ethnographic archival data collected in Croatia from the beginning of the 20th century until 1989 reveal that St. Martin as the patron saint of viticulture is venerated mostly in the western part of Croatia, including Dugo Selo. The Day of St. Martin is celebrated on November 11, when this saint ended his earthly life. Additional recently introduced reference to St. Martin in Dugo Selo calendar is July 4, the Summer Day of St. Martin, which commemorates Martin's appointment as a bishop in the year 371 (which will be discussed further on). In this area, the Feast of St. Martin on November 11 is marked by the custom of the baptism of wine, with St. Martin frequently being recognised as the one who baptises wine (see Belaj 2006: 142). The custom involves the baptism of must, which is then drunk to the enjoyment of the participants, all garnished by a banquet, the recurrent culinary peak of which is roast goose with mlinci, a type of popular homemade dough. The hedonistic character of this custom is probably the very cause for its spreading throughout Croatia at the end of the 20th century, even to places where St. Martin's feast had never figured as an important event in the past (Zaradija Kiš 2004: 107), as well as to places where throughout the entire 20th century patronage over vineyards and wine had been the prerogative of St. Vincent, for instance, in northern continental Croatia (Belaj 2006: 143).

Records from 20th-century Croatia indicate that St. Martin's role as a patron saint also encompassed other areas of life. For instance, he was known as the guardian of cattle, mainly in north-western Croatia. In the northern Croatian Littoral there are documented cases of his patronage of women in labour, of the dying, and of fields (ibid.: 91, 98, 140, 179, 181, 186, 188). During the 20th century St. Martin was remembered on his holiday as a marker in the agricultural annual cycle: this was the first day for the yearly slaughter of pigs and the day when horses were taken to the stables for the winter. This 
day marked the end of the agricultural year and the beginning of the winter quiescence (ibid.: 190, 262).

Although ethnographic archival data on the veneration of saints and celebrations of their feasts dating from the 20th century are rather sparse and meagre, they are a valuable source because they reveal areas of life that during the Communist period were by and large relegated to the private sphere.

\section{ON THE MARGINS OF COMMUNISM}

Based on the already mentioned archival data on the veneration of saints during the 20th century, St. Martin's main role in the Dugo Selo area was that of the patron of vineyards, whose feast was marked by the baptism of wine, a custom focusing on the transformation of must into young wine. This scant information about the Martinmas celebration in Dugo Selo, encompassing also the Communist period, is virtually the only evidence proving that the holiday was not entirely eradicated by Communist repression. During the 45 years of the Communist one-party system that Croatia experienced as part of the Socialist Federal Republic of Yugoslavia, St. Martin - just like all else of a religious nature - was marginalised and suppressed in public discourse. During that period the construction of the identity of Dugo Selo, same as all the other Yugoslav towns, was based on the Yugoslav socialist imagery, whose key topics were Josip Broz Tito, the People's Liberation Movement, and the Communist Party, which were inscribed into the names of streets and squares, into monuments, into the decoration of public institutions, local calendars and programmes of events, etc. In this infiltration of Yugoslav socialism into town life, the local newspapers played an indispensable role - in the case of Dugo Selo this was Dugoselska kronika (The Dugo Selo Chronicle), as the main local paper, published since 1967.

In that period the Dugoselska kronika followed the activities of the local administrative and political bodies and organisations, the Communist Party in particular, and celebrated the successes and memories of the People's Liberation Struggle during World War II, by following various dates from recent local (socialist) history. Particular attention was devoted to two events: the Battle of Oborovo, which took place on March 29, 1944, when 152 partisans were killed; and the Liberation Day of May 8, 1945, when partisan units entered Dugo Selo. The commemoration of these two dates played such an important role in the Dugo Selo calendar that they were successively chosen to mark the Municipal 
Day: the former in the 1970 s and the latter in the 1980s. It would appear that, beginning in the $1980 \mathrm{~s}$, the town was coming out of bereavement, increasingly associating the celebration in the narrower sense with a more cheerful concept (liberation), although the death of 152 people in Oborovo would continue to be commemorated to this day.

At the same time, during the Yugoslav Communist period, the Dugoselska kronika was mute as regards major Christian holidays, including Martinmas. Occasionally, but very rarely, St. Martin's Church on Martin Breg would figure, but invariably as a lifeless cultural-historical monument devoid of any religious attributes whatsoever. For instance, in an extensive article the author draws attention to the need to protect the church (see Crnić 1970: 4), while in another, which excellently underscores the spirit of the period, the unsigned author writes about the remains of the church with obvious caution and reserve:

It is entirely beside the point here that this is a church; this is irrelevant both for theism or atheism. [...] It is an entirely different question whether or not this edifice could or should have been spared from ruination and preserved for the 21st century. But this is not the subject of this text. (Martinska 1988: 12)

It is only with the beginning of the 1990s that texts about this church would start appearing with increasing frequency, to which we shall return later in the text.

Be that as it may, the inhabitants of Dugo Selo recount that during that period the Feast of St. Martin was nevertheless celebrated as the most important day - alongside Christmas and Easter - of the Dugo Selo parish. "St. Martin's Day was always celebrated with a liturgy," says the present-day parish priest, adding that the public celebration was strictly confined inside the church fence. Simultaneously, Martinmas was celebrated as the day of 'baptism' of young wine in the vineyard huts of the inhabitants of Dugo Selo. To be precise, on Martinmas or around that date the men would go to the vineyards to rack the must into clean barrels, and then they would 'baptise' the must with a bell and a prayer book: "St. Martin has arrived and arrived, he would baptise it, I would drink it" (Remenar 2013: 10). On those occasions they would invite each other to their huts, singing wine songs and feasting on sausages, bacon and cheese, while those more affluent would offer a goose with mlinci. These parties are reserved for men only, who would return to their homes in the morning to the toll of bells, announcing that "the must has been baptised". 


\section{EXTRACTION FROM OBLIVION}

The tide turned towards the end of the 1980s, just like in the rest of Eastern Europe. Croatia entered the period of multiparty democracy, which was soon followed by the dissolution of Yugoslavia and Croatia's independence. The beginning of the 1990s was a time of intense national enthusiasm, marked by the struggle to preserve independence in the Homeland War. Local papers of the period bear witness to the renewed interest of the community in national and religious topics. Religion was no longer considered 'dangerous', nor was the Church the 'enemy of the people' any more. What is more, religion and national identity were deemed to have been inextricably linked.

A full half year had gone by since the first multiparty election before, at the end of 1990, the local papers published two articles featuring life in the local church under the headings Kardinal posvetio novi oltar (Cardinal consecrates the new altar) (Gale 1990a: 3) and Koncert u župnoj crkvi (A concert in the parish church) (Gale 1990b: 5). As innocuous as the titles of these short texts may be, they would have been inconceivable in the paper's previous editorial policy. These two texts opened the newspaper space for local religious topics. From then on, the editorial board of the paper has never failed to mark Christian holidays with corresponding texts. Moreover, it has educated, or at least reminded local readers of the appropriate holiday adornment, providing recommendations of sorts as to "how to decorate the surroundings of their buildings" for Christmas holidays (Načinimo 1990: 12), pointing out that the "Christmas and New Year holidays are [...] an opportunity to recall the somewhat forgotten customs that had always been present in the Dugo Selo area" (Fotović 1990: 1).

Articles focusing on the old church of St. Martin on Martin Breg now started appearing with increasing frequency. They featured in almost every issue and were all written by the same journalist, Nenad Haleuš-Mali. Moreover, it appears that the church was increasingly materialising on the horizon of the local community. The titles themselves are evidence enough to perceive the increasingly more active and caring attitude towards the church: Što se poduzima da se Martinska crkva otrgne mraku propadanja: Radi se i razmišlja (What is being done to seize St. Martin's Church from the clutches of decay: Acting and thinking) (Haleuš-Mali 1991a: 8); Što kriju spisi (What are documents hiding) (1991b: 1); Pala lukovica tornja (The steeple dome collapses) (1991c: 1); Zaštita spomenika u ratnim uvjetima (Protection of monuments in war conditions) (1991d: 8); Rat spriječio radove: Zaštita Martinske crkve (War stops works: Protection of St. Martin's church) (1991e: 6); Nemila sudba dugoselske crkve (The tragic fate of the Dugo Selo church) (1992a: 7); Dočekali smo radove na Martinskoj crkvi (At long last the work starts on St. Martin's church) (1992b: 1); 
Skrb za svetoga Martina (Caring for St. Martin) (1992c: 8); Hoće li stati obnova sv. Martina (Is the reconstruction of St. Martin's about to halt) (1992d: 12); etc.

In 1991 the war events dominated the pages of the Dugoselska kronika. Military operations and the sharpening issue of refugees were burning topics that left no room for the culture of celebration, especially that of St. Martin's Day, which in that year was overshadowed by the fiercest fighting for the eastern Croatian town of Vukovar.

\section{MARTINISATION}

Martinmas earned a place in the Dugoselska kronika as late as 1992, but it did so in grand style. This was the first mention of the feast in the local paper that by then had been published for almost 25 years. In that first appeal to the Dugo Selo inhabitants to "celebrate St. Martin" it was mentioned that Martinmas had been celebrated in the area "for centuries", and that the "tradition was neglected during the past period" (Svetkovanje 1992: 1). According to the paper, the planned celebration of the feast included a three-day programme, whose mainstay was cultural and artistic performances based on the local folklore, and sports competitions between local clubs. The planned climax, that is, "the central act of the programme", was the "baptism of the must (according to age-old customs)" (ibid.). The same issue included visual and literary works by elementary school pupils from Dugo Selo with the old church on Martin Breg as the prevailing motif (see Žuta 1992: 7). And, finally, the entire last page of the paper featured a selection of excerpts from works by Dugo Selo writers, which, true enough, could only indirectly be associated with Martinmas. Even so, the editor of the article points out:

[---] looking at a broader picture, Martinmas is not just a day of the year, but much more - vineyards, vineyard huts, grapevines and labour around vines, all that begins in early spring and lasts until Martinmas. What is more, when we discuss the Dugo Selo area, this extends also to the church of St. Martin, which, in the words of the poet Slavko Vuric, is the 'complimentary guardian of our vineyard huts'. (Brajdić 1992: 12)

The title is given in the local dialect: Nikaj ni lepše nek v kleti biti, Martinje slavit $i$ moštek piti... (Nothing can match being in the vineyard hut, celebrating Martinmas and enjoying the must...), while in the introduction of the review the editor paints Martinmas as "one of those holidays and popular customs that are increasingly disappearing from the life of our towns and villages, in which the Dugo Selo area is no different from the rest" (ibid.). This prompted the editor 
to first provide a brief review of the customs associated with Martinmas, based on a very concise description of the customs in the villages north and south of Zagreb during the first half of the 20th century, written by ethnologist Ivanka Bakrač (see Bakrač 1988: 366-367). Apart from the fact that her description refers to the pre-Communist period, it should also be pointed out that although it might contain certain elements of the custom that were present also in Dugo Selo, the town itself and the surrounding area did not feature in the research by this ethnologist. Most excerpts from literary works chosen by the editor in fact contain no mention of St. Martin or Martinmas at all, but rather thematise the Dugo Selo landscape, scattered with vineyards and vineyard huts, as well as the chanting of wine songs and drinking of wine. Therefore, in this editorial interpretation St. Martin and Martinmas are equated with a much broader phenomenon, the culture of wine. The article contains also two songs inspired by St. Martin's Church and its environment, as well as the deterioration thereof. However, this selection of works by Dugo Selo writers includes two poems by a Dugo Selo poet, Milan Dobrovoljac Žmigavac (1879-1966), which directly thematise Martinmas, that is, details associated with this holiday. For instance, in the poem $K$ Martinju (Come Martinmas) the poet describes in humorous terms the forlorn and despondent ramble of geese around the courtyard in view of the impending arrival of Martinmas as their "judgement day", alluding to the custom by which a roast goose must adorn every table at Martinmas. The second poem of the same name celebrates the custom of the "baptism of the must" in vineyard huts, garnished by a plentiful feast, and the commotion that accompanies its preparation. However, this entire description is subordinated to the main emphasis of the poem, which is to point out this custom as an important determinant of Croatian national identity. The poet rhetorically asks himself:

Tko više štuje od nas Hrvatov

Toga patrona svih vinskih bratov?!

Who could be better than us, the Croats

in honouring this patron of all wine-lovers?!

He ends the poem with these verses:

Martina svetog koji ne štuje,

Taj na horvacke šege vam pluje,

Taj-o tom nema niti debate -

Nemre med prave spadat Hrvate!

Lack of respect for Martin the Saint, Is a spit in the eye of Croatian faith, 
He who does this - there is no doubt -

Could never and ever be a true Croat!

These verses at the same time mark the end of the editorial item. The alliance of the religious-customary and the national in a poem from a somewhat earlier time in history received a new welcome in this period of renewed awareness and resurrection of Croatian national identity, which at that time was, as a rule, equated with religious affiliation, namely with Catholicism. At the same time, this newspaper item as a whole heralded the triumphant return of St. Martin and Martinmas into the public life of Dugo Selo. From that moment on, the saint and his holiday would figure as the main elements in the process of the new symbolisation of Dugo Selo: a process that would be defined by terms such as the 'centennial tradition of St. Martin's', that is, by the alliance of the town, St. Martin's Church and Martin as the patron saint and the saint of wine, but also an alliance between the local and the national. In that vein, the editorial board of the Dugoselska kronika, in an article entitled Oživljen duh Martinja (The spirit of Martinmas reawakened), occupying the front page, reminds their fellow citizens that "St. Martin is the patron saint of Dugo Selo. He is the patron saint of the Dugo Selo parish and Martin Breg was named after him, together with its most beautiful landmark: the old church of St. Martin. To this one can also add vineyards and Martinmas" (Oživljen 1992: 1). The middle spread of the same issue featured an extensive report from the just completed threeday celebration of St. Martin's feast, describing the "renewed celebration of Martinmas", "the once traditional celebration of Dugo Selo", held "after many years", expressing the intention that these "traditional celebrations continue to be held in the future" (Da se nastavi 1992: 6). Unlike the above-mentioned announcement of the celebration, this report provides the first details about the celebration: it included an exhibition of books, publications and documents on Dugo Selo; an outdoor selling exhibition of domestic breads and cakes; passers-by were treated to a demonstration of the distillation of brandy (!) in an old cauldron, topped by tasting; traditional costumes were displayed; matches between local handball and football teams were organised; elementary school pupils held performances featuring St. Martin and Martinmas and, finally, a grand party was organised in the Croatian Army Centre. The party culminated with a performance of the "baptism of the must", with a 'bishop' and an 'acolyte', who 'baptised' a barrel of new wine with smoke from a censer. In the final words of the report, "[---] this was an unforgettable night in Dugo Selo [---] How could it not have been considering that 400 litres of freshly baptised must were drunk in the Croatian Army Centre?" (ibid.: 7) The celebration of Martinmas ended with a holy mass, which was "prepared and held in a particularly solemn manner" in the parish church of Dugo Selo, "teeming with the faithful" (Oživljen 1992: 1). 
A year later, the Feast of St. Martin was declared a municipal holiday by the decision of the Dugo Selo Municipal Council (Službeni 1993: 1). From then on Martinmas would be announced each year as the Municipal Day.

A clear illustration of just how great a momentum the process of "the resuscitation of St. Martin's spirit" has taken on in this period is provided by a newspaper article significantly titled Martinizacija (Martinisation), signed with the humorous pseudonym Martina Martinska. The text tells of how "the Spirit of St. Martin was reawakened like Aladdin, who accidentally surfaced to the light of day after a series of centuries spent inside a magic lamp. However, instead of serving his master, St. Martin's Spirit came to rule over us and our streets, taverns, houses - in short, over our Dugo Selo reality" (Martinska 1994: 12).

The author inventories the assets that came under Martin's portfolio, namely private companies, stores, guesthouses, galleries, a radio station, the Croatian Army Centre, an information guide through Dugo Selo with the surroundings, etc. The author found the Spirit of "St. Martin of Dugo Selo" and the "Martinisation trend" to be so assertive that she "feared", jokingly, of course, that Dugo Selo might change its name into Martin Grad (Martin Town). Yet, this was a lonely voice of resistance to the general Martinisation that was under way.

At that time, St. Martin was awarded a role in the celebration of the Statehood Day in Dugo Selo, which at the time was celebrated in spring, on May 30. Specifically for this occasion, the environment of the old church of St. Martin on Martin Breg was cleaned and decorated in order to host the manifestation precisely in that place. For the first time in 47 years, a mass was held there (in the open air), and the same day also saw the first exhibition of wines from the Dugo Selo and Vrbovec vineyards, as one of the main elements of the Martinmas image in the making (Povratak 1995: 6-7).

On the eve of the Martinmas of 1995, a 7-metre wooden statue of St. Martin, a work of the sculptor Josip Cikač, was erected near the church on Martin Breg. The article titled Nastavlja se svetomartinska povijest (The history of St. Martin's continues) casts Martin Breg with the new statue as a "pedestal to the venerated saint, the patron of our parish" and a "place that symbolises Dugo Selo and its surroundings". However, the statue was ascribed much broader meanings in addition to this local one. In the unveiling of the statue, art critic Juraj Baldani associated it with the Croatian national identity:

The tree is a symbol of our lands, a symbol of suppleness, [...] a symbol of growth, something that is unstoppable. Even if you cut it, it continues to grow. The Croatian people demonstrated their closeness with the tree. They wanted to cut us down, but we grow, like St. Martin has grown. For Croats the statue is, among other things, a symbol of freedom and all that we have today. 
At the ceremony, the then head of municipal government announced that the erection of the statue was only the beginning in the cultivation of Martin Breg, which would soon be followed by the reconstruction of the Martin Breg church (Nastavlja 1995: 1). The newly-erected statue would soon serve as a model for the creation of the Dugo Selo souvenir, ${ }^{1}$ and it also acquired a place in tourist brochures, for instance, in the following brief description of Dugo Selo:

An indelible mark upon the history and culture of this area has been imprinted by the name of St. Martin and by the Knights Templar. The oldest cultural and historic monument in Dugo Selo is the church of St. Martin [...] while at the foot of the church rises a $7 \mathrm{~m}$ tall wooden statue of St. Martin. A small version of it is an official souvenir of the town. (Dugo Selo 2011: 33)

When Dugo Selo was promoted to the status of a town, Martinmas ceased to be the Municipal Day and became the Town Day.

\section{A RETURN TO EUROPE}

The shaping of the identity of the town based on the tradition of St. Martin acquired a new dimension in the subsequent period, when certain new guidelines were added to the entire process. The 1995 announcement of the head of municipal government of Dugo Selo regarding the reconstruction of the Martin Breg church finally started materialising in this period. The town administration of Dugo Selo at that time initiated archaeological investigations as a precondition for reconstructing the church, and commissioned the Institute of Archaeology in Zagreb to carry out the excavation. The latter commenced the investigations in and around the Martin Breg church in 2002, under the leadership of one of the authors of this paper. From the present perspective and in the context of the topic of this article, we believe that this move by the town administration clearly reflects a change of policy of the town towards heritage, and the new plans the town has for that heritage. It is obvious that additional footholds were sought in the process of the further construction of the town's identity.

Before we proceed to briefly sketch the results of archaeological investigations relevant for the topic of this article, let us return to the already mentioned charter by King Andrew II Arpad from 1209. As we have noted, this is the oldest known written document about life in this area. By the charter the king granted the Land of St. Martin to the Knights Templar. The name of the granted land suggests that a church of St. Martin had already been there by that time. It is believed that the first church dedicated to St. Martin was erected 
at the time when Frankish missionaries were spreading Christianity in these lands (Buturac 1981: 15); since St. Martin was the patron saint of the Frankish kings and army, it is more than probable that it was precisely his cult that was used in Christianising the population. In addition to this, studies dealing with the reconstruction of the Slavic sacred landscape (J. Belaj 2009; V. Belaj \& J. Belaj 2014) have shown that in certain places St. Martin was deliberately chosen in the process of Christianising the Croats and Slavs, generally to supersede the supreme Slavic deity, Perun the Thunderer. Important for this process were those 'pagan' elements from St. Martin's biography that could facilitate the transition from the old religion to a new one for the Slavs (e.g. St. Martin's association with a millstone, the world of the dead, fires, wolves, bears, shepherds, his fight with the Devil, the fact that he rode a horse, etc.). The position of St. Martin's Church is special, with an open view to all the sides of the world. As the mentioned studies show, this is a holy place once 'inhabited' by Perun the Thunderer, which was concluded based on the spatial relationship with other positions with significant toponyms. Namely, one of the increasingly more numerous 'triangular' pre-Christian holy spaces - Martin Breg - Veleševec - Trebovec (ibid.) - is recognised in Dugo Selo.

After the Knights Templar, in 1314, the church on Martin Breg passed under the rule of the Knights Hospitaller. Both these knightly orders had their house (domus) on this extensive estate (preceptory of St. Martin). As the end of the Middle Ages drew nearer, the Hospitallers started to leave the lands, while Turkish incursions were becoming more frequent, bringing in a period of serious recession to the entire area. The old church was destroyed during these turbulent times. The core of the presently visible church was built in the latter half of the 15th century in Late Gothic style. Since then the church has been damaged and reconstructed a number of times. The great earthquake of 1880 dealt a final blow to it, and it was soon abandoned in its wake. The new church was built in the present-day centre of Dugo Selo, and it also bears the name of St. Martin.

The archaeological excavations at Martin Breg were conducted between 2002 and 2008. For the time being, they have shown that there are only rare finds from the pre-Templar phase of the church. For instance, one of the few finds bearing testimony to that phase of the church, and probably to the cemetery around it, is the jewellery of the local inhabitants from that time. The reason for the scant presence of finds from the pre-Templar horizon of the church primarily lies in the later intensive building activity at the site and, even more so, in the burials in and around the church extending far into the modern period.

The most eloquent sign of the presence of the Templars is the finding of a tombstone with a shield and sword carved in low relief. From the same period 
comes a silver Slavonian banovac coin, minted in Zagreb between 1310 and 1316 , as well as the large and expensive stone blocks built into the later phase of the church. The investigations also yielded the foundations of a Romanesque church, whose two-metre width speaks in favour of the assumption that the building was a church-fortress of the Templar Order. On top of the foundations of the Romanesque apse of the Templars, the Hospitallers later laid the foundations of their Gothic phase of the sanctuary, which at that time was polygonal with pillars. There are several portable finds from that period, when the Knights of Saint John ruled this estate. One of the two square rooms added to the church in the north yielded several coins of King Sigismund, and mid-15th-century pfennigs that had fallen behind the stone base of an altar. A burned context in the other room yielded a number of fragments of collapsed ceramic - unglazed stove tiles from the turn of the century, i.e., about 1500 . The remains are assumed to belong to a domus of the Hospitallers.

The majority of finds from both graves and layers belong to the modern period. These are again coins, followed by saintly medallions that often contain apotropaic inscriptions. Another common find is various small crosses that during the years of plague also assumed a protective role. Some graves yielded rosary beads - small silver symbols of Christ's passion inserted into a luxurious rosary. Other common modern-period finds are certainly buckles, buttons and similar accessories that were sewn onto clothes in which the deceased were buried.

The archaeological investigations were regularly covered by the local newspaper, which comes as no surprise since the town of Dugo Selo was not only the initiator but also co-financier of these investigations. Moreover, as was revealed soon, the assumed association of the church with the Order of the Knights Templar also became one of the mainstays in the creation of the town's desired identity. It was expected that the commissioned archaeological investigations would be the very means of the scholarly verification and evaluation of the connection of the Knights Templar with this area. Several years into the investigations, in 2007, the town administration initiated the publication of the results of the archaeological excavations, once again providing the financial wherewithal. Therewith, the original wish of the administration in Dugo Selo was to promote the presence of the Templars only, having no interest in the other results, since they did not fit in the image-building strategy of the town. Upon the insistence of the author - also a co-author of this paper - the topic of the book was eventually expanded. It finally became clear even to the town administration that the finds from the Templar period were too few for a book envisaged as a representative monograph of the Templar presence in this area. In the end, the book covered also the other results of the archaeo- 
logical investigations, and it was published under the title Templari $i$ ivanovci na zemlji svetoga Martina (Templars and Hospitallers on the Land of Saint Martin) (Belaj 2007).

Even so, in the Dugo Selo reinterpretations of the archaeological results only the history of the Knights Templar was exploited. All the more so, the 'Templar', youngsters dressed in "Templar uniforms, with equipment and recognisable insignia", were chosen to represent cultural tourism projects in Dugo Selo (publication of the book Templari $i$ ivanovci na zemlji svetoga Martina, the revitalisation of the central zone of Martin Breg, the forthcoming 800th anniversary of the mention of the Land of St. Martin) at the exhibition of the County Tourist Board within the International Tourism Fair held in Zagreb in 2007 (Kozić 2007: 1). The Templars performed a central role also in the exhibition days of the Templars in Dugo Selo, organised in 2010 on the premises of the Zagreb County Tourist Board. ${ }^{2}$ In the same vein, the Templars were the main motif of the events organised at the beginning of July, connected to the Summer Day of St. Martin, i.e., the day commemorating Martin's appointment as a bishop on July 4, 371. The events include a knight tournament, mediaeval cuisine, display of knightly equipment and crafts, children's Templar games and other activities. ${ }^{3}$ The ties with the Templars and the historical period are constructed by means of chronological coordinates of the Middle Ages (for instance, 'mediaeval cuisine', 'mediaeval customs') and precise temporal markers - performance of "delivering the charter by which, in 1209, King Andrew II of Croatia and Hungary granted the Land of St. Martin to the knights - Templars". ${ }^{4}$ Further historical foundation is construed by a spatial reference: the international knight tournament "is again taking place in the authentic historical location, below the old church of St. Martin". ${ }^{5}$ By chronologically and spatially anchoring the event, the Templars are placed into the historical spaces of Martin Breg and Dugo Selo, unambiguously guiding the participants to the key in which they can read the knights' equipment and scenes "at the same place, below the old church, where long ago convened the then owners of the 'Land of St. Martin', the Templars". ${ }^{6}$

The new interpretation of the history of Dugo Selo mentions that the Templars themselves chose the titular, St. Martin. As most Templars were French, they indeed frequently dedicated their churches to St. Martin, a bishop from Tours in France (Dobronić 1984a: 23; 1984b: 115), but in Dugo Selo it is often conveniently neglected that, as we have already stated, St. Martin had been present in these lands even before the arrival of the knightly orders. The rewriting of the history of Dugo Selo with two key motifs, St. Martin and the Templars, was aimed at forging intensive relations of the town's history with 
the broader European heritage. In this, from the perspective of Dugo Selo, the Templars and St. Martin were understood as pro-European symbols par excellence and, what is more, in synergy with each other.

The connection with the European heritage was confirmed in 2007, on the Summer Day of St. Martin. On that day the St. Martin Cultural Centre Croatia in collaboration with the European Cultural Centre of St. Martin of Tours and representatives of the town and the church, placed on the remains of the Martin Breg church a metal relief footprint of St. Martin. By this act Dugo Selo symbolically joined the network of many European places sharing the tradition of St. Martin in a European cultural itinerary "that follows the routes of St. Martin" (Grgić Ozimec 2007: 1). Furthermore, a map of European towns marked with the footprint of St. Martin was placed in front of the church. In addition to the many guests, the event was attended by the director of the European Cultural Centre of St. Martin of Tours, the French ambassador to Croatia, the Croatian ambassador to France, as well as the bishop of the Hungarian city of Szombathely, the birthplace of St. Martin according to a legend. The ceremony was accompanied by a costumed squad of 'Templars', and the guests were offered 'Templar biscuits' in the shape of the 'Templar shield', as well as 'Martin croissants' and 'Templis' wine.

A year before the accession of the Republic of Croatia to the European Union, on July 1, $2012^{7}$ (on the occasion of the Summer Day of St. Martin) a stone marker of St. Martin's Route was placed next to the church on Martin Breg, as part of another project of the mentioned Cultural Centres of St. Martin. The marker "conceived on the model of milestones from the 4th century, from the time of St. Martin", signifies the four cardinal directions, with an additional pointer in the direction of Tours. The pro-European orientation of this act was repeatedly accentuated in the commemorative speeches by a number of guests. For instance, the local parish priest, Slavko Kresonja, pointed out that St. Martin "17 centuries after his death manages to unite the peoples of Europe", while Ines Sabotič, the director of the St. Martin Cultural Centre (Croatia), stressed that "this was the first mark of the future pedestrian highway through which we shall set foot in Europe, and, vice versa, all in honour of the saint that unites us". "With this we symbolically return to where we belong - to Europe, to where we shall officially accede on this very day next year," said Ivan Gereci, Deputy Mayor of Dugo Selo (see Grgić Ozimec 2012: 11), on that occasion. The use of the European Union flag as a veil for the monument in the ceremony once again underscored St. Martin's role as the symbol of the pro-European orientation of the local community. 


\section{SAINT MARTIN: CONSTRUCTIONS AND INTERPRETATIONS}

St. Martin as a symbol offers various possibilities for interpretative constructions, facilitating his exploitation in legitimising ideological goals. It appears that the same had already happened upon his arrival in these lands with the Frankish missionaries in the 9th century. Since he was the patron saint of the Frankish kings and army, it is very likely that Frankish missionaries knowingly picked St. Martin in the process of the (re)Christianisation of these lands, using his special non-saintly features to suppress the pre-Christian Slavic cult of Perun. In time the 'pagan' traits of Martin's personality that he had brought with him from Gaul into our lands were gradually forgotten. The Christian values of this saint came to the fore. We can easily imagine him arriving like a soldier with a sword, riding a horse. As a historical person, he indeed was a soldier, and is often depicted with such iconography. Therefore, even though there are grounds for discussing the long history of harnessing St. Martin's symbolism for achieving specific aims, we focused our research on the recent decades and the construction of heritage in the name of recent political goals.

St. Martin, who was confined to the margins of the public sphere throughout the second half of the 20th century, was launched, in the wake of political changes, into the centre of local symbolisations. His feast started to be celebrated as the Day of the Municipality and, later on, that of the town, while the ceremonies, limited in the previous socialist period to the church precinct, started to feature rich and varied programmes. Besides, during the politically turbulent 1990s, the local characterisation by this saint started acquiring broader, national hues. Finally, during the period of Croatia's approaching the European Union, St. Martin evolved into a saint that "unites the peoples of Europe" and "brings Croatia back to where it belongs". In addition to these visible changes in the interpretation of St. Martin, and in the presence of the events associated with him in Dugo Selo, there is also the intention to materially inscribe the saint permanently into the landscape. On the one hand, by commissioning experts and providing financial support to the investigations, the town authorities have decided to incorporate the physical remains into the desired image of their town. On the other hand, new material symbols appear in the area: the seven-metrehigh wooden statue of St. Martin, the metal relief footprint of Saint Martin, the map of European St. Martin towns and the stone marker of St. Martin's Route. The physical remains of the past and the newly-placed signs thus become visible markers of the selected values and eloquently speak of the creation of the desired cultural identity. Highlighted in the local landscape, they are at the same time clearly connected with a European network, placing a small Croatian 
town on the European cultural map, at a time in which Croatia positions itself on the political map of the European Union.

The construction and interpretation of heritage as described by Hannam and Knox is a possible key to reading the intents of the Dugo Selo authorities. In their words, "heritage industry [---] is inherently about the telling of stories, and the association of those stories with historic sites, landscapes, artefacts and people" (Hannam \& Knox 2011 [2010]: 156). The story of the Land of St. Martin and the Templars, through the efforts of local authorities, is associated with the physical remains and new signs of 'St. Martin's heritage' that would bear witness to the European visibility of Dugo Selo. The local authorities came to the idea to enhance the process of equating present-day Dugo Selo, on the one hand, and St. Martin and the Templar Order on the other, by including experts whose investigations would serve to render the story connected with "historic sites, landscapes, artefacts and people" (ibid.) more convincing and more powerful. The moments in which St. Martin was positioned as a prominent saint of Dugo Selo in the past two decades were first connected with the local and national circumstances, and later also with the broader European framework. This confirms that under the influence of "contextual power relations" (ibid.: 152) meanings can be ascribed even to ostensibly clear and cold physical remains and that they, too, lend themselves well to various contemporary constructions and uses of heritage. These processes are marked by selectiveness and partiality, into which the discourse about the authenticity of historical sites is woven, which is further legitimised on the basis of scientific research; they are shown as changeable and sensitive to political and social circumstances. The temporal and spatial points of archaeological finds and the imagery of the Templars and St. Martin have been strategically harnessed to the creation of the desired image of the town.

\section{NOTES}

1 See the website of the Zagreb County Tourist Board: http://www.tzzz.hr/mjesta/dugoselo/crkva-na-bregu/, last accessed on March 3, 2015.

2 See the website of the Dugo Selo Tourist Board: http://www.tzds.hr/otvorena-izlozba$\% \mathrm{C} 2 \% \mathrm{ABdani}$-templara-u-dugom-selu\%C2\%BB/, last accessed on January 29, 2015.

${ }^{3}$ See the website of the Dugo Selo Tourist Board: http://www.tzds.hr/vitezovizelingradski-ozivjeli-srednji-vijek-u-dugom-selu/; http://www.tzds.hr/templari-usubotu-uspjeli-obraniti-svoju-utvrdu/, both last accessed on March 3, 2015.

4 See the website of the Dugo Selo Tourist Board: http://www.tzds.hr/vitezovizelingradski-ozivjeli-srednji-vijek-u-dugom-selu/, last accessed on January 29, 2015. 
5 See the website of the Dugo Selo Tourist Board: http://www.tzds.hr/medunarodniviteski-turnir-03-04-srpnja-2010/, last accessed on January 29, 2015.

6 See the website of the Dugo Selo Tourist Board: http://www.tzds.hr/templari-u-subotuuspjeli-obraniti-svoju-utvrdu/, last accessed on January 29, 2015.

7 The event took place on Sunday, July 1, because that year the Summer Day of St. Martin fell on a Wednesday, which was a working day.

\section{REFERENCES}

Bakrač, Ivanka 1988. Godišnji i radni običaji u okolici Zagreba. [Seasonal and Work Customs in Zagreb Surroundings.] In: Mario Petrić \& Marijan Sinković (eds.) Etnografska baština okolice Zagreba. [The Ethnographic Heritage of the Zagreb Surrounding Area.] Zagreb: Zadružna štampa, pp. 363-378.

Belaj, Juraj 2007. Templari i ivanovci na zemlji svetoga Martina. [The Knights Templar and the Knights of St. John on Saint Martin's Land.] Dugo Selo: Pučko otvoreno učilište Dugo Selo.

Belaj, Juraj 2009. Martin-Breg između poganstva i kršćanstva. [Martin-Breg between Paganism and Christianity.] Studia ethnologica Croatica, Vol. 21, No. 1, pp. 7999. Available at http://hrcak.srce.hr/search/?q=Martin-Breg+izme\%C4\%91u+pog anstva+i+kr\%C5\%A1\%C4\%87anstva, last accessed on January 29, 2015.

Belaj, Marijana 2006. Sveci zaštitnici u hrvatskoj pučkoj pobožnosti. [Patron Saints in Croatian Popular Religiosity.] Doctoral thesis. Zagreb: Sveučilište u Zagrebu, Filozofski fakultet.

Belaj, Vitomir \& Belaj, Juraj 2014. Sveti trokuti: Topografija hrvatske mitologije. [Sacred Triangles: Topography of Croatian Mythology.] Zagreb: Ibis grafika \& Institut za arheologiju \& Matica hrvatska. Available at http://www.academia. edu/8440508/Vitomir_Belaj_i_Juraj_Belaj_SVETI_TROKUTI._Topografija_ hrvatske_mitologije_Sacred_Triangles._Topography_of_Croatian_Mythology_O_ knjizi_About_book_, last accessed on January 29, 2015.

Bendix, Regina 1989. Tourism and Cultural Displays: Inventing Traditions for Whom? Journal of American Folklore, Vol. 102, No. 404, pp. 131-146. http://dx.doi. org/10.2307/540676.

Brajdić, Ivan 1992. Sveti Martin, Martinje i Martin breg u djelima dugoselskih pisaca. Nikaj ni lepše nek v kleti biti, Martinje slavit i moštek piti... [Saint Martin, Martinmas and Martin Breg in the works of writers from Dugo Selo. Nothing can match being in a vineyard hut, celebrating Martinmas and enjoying the must...] Dugoselska kronika, No. 330, p. 12.

Bruner, Edward M. 2005 [2004]. Culture on Tour: Ethnographies of Travel. Chicago \& London: The University of Chicago Press.

Buturac, Josip 1981. Božjakovina-Brckovljani 1209-1980: Iz povijesti župe, uprave $i$ gospoštije. [Božjakovina-Brckovljani 1209-1980: From the History of the Parish, Administration and Allodium.] Brckovljani \& Zagreb: Hrvatsko književno društvo sv. Ćirila i Metoda. 
Crnić, Ivica 1970. Biti ili ne biti - martinske crkve? [To Be or not to Be - for St. Martin's Church?] Dugoselska kronika, No. 32, p. 4.

Da se nastavi 1992 = Da se nastavi tradicija. [To Continue the Tradition.] Dugoselska kronika, No. 331, pp. 6-7.

Dobronić, Lelja 1984a. Viteški redovi: Templari i ivanovci u Hrvatskoj. [Knightly Orders: Templars and Hospitallers in Croatia.] Analecta Croatica Christiana, Vol. XVIII. Zagreb: Kršćanska sadašnjost.

Dobronić, Lelja 1984b. Posjedi i sjedišta templara, ivanovaca i sepulkralaca u Hrvatskoj. [Estates and Seats of the Knights Templar, Knights Hospitaller and Knights of the Holy Sepulchre in Croatia.] Rad JAZU 406. Zagreb: JAZU.

Dugo Selo 2011 = Dugo Selo: In the Spirit of St. Martin. Way to Croatia, No. 11, p. 33.

Fotović, Krešimir 1990. Dugoselski Božić. [Dugo Selo Christmas.] Dugoselska kronika, No. 310, p. 1.

Gale, Tomislav 1990a. Kardinal posvetio novi oltar. [Cardinal Consecrates a New Altar.] Dugoselska kronika, No. 309, p. 3.

Gale, Tomislav 1990b. Koncert u župnoj crkvi. [Concert in a Parish Church.] Dugoselska kronika, No. 309, p. 5.

Grgić Ozimec, Iva 2007. Otisak "stope sv. Martina" na staroj crkvi. [A Cast of "The Footprint of St. Martin' on the Old Church.] Dugoselska kronika, No. 493, p. 1.

Grgić Ozimec, Iva 2012. Dugom Selu prva oznaka svetomartinskog puta u Hrvatskoj. [Dugo Selo Marked as the First Croatian Site on the Route of St. Martin of Tours.] Dugoselska kronika, No. 555, p. 11.

Haleuš-Mali, Nenad 1991a. Što se poduzima da se Martinska crkva otrgne mraku propadanja: Radi se i razmišlja. [What Is Being Done to Seize St. Martin's Church from the Clutches of Decay: Acting and Thinking.] Dugoselska kronika, No. 316, p. 8.

Haleuš-Mali, Nenad 1991b. Što kriju spisi. [What Do Documents Hide.] Dugoselska kronika, No. 317, p. 1.

Haleuš-Mali, Nenad 1991c. Pala lukovica tornja. [The Steeple Dome Collapses.] Dugoselska kronika, No. 317, p. 1.

Haleuš-Mali, Nenad 1991d. Zaštita spomenika u ratnim uvjetima. [Protection of Monuments in War Conditions.] Dugoselska kronika, No. 318, p. 8.

Haleuš-Mali, Nenad 1991e. Rat spriječio radove: Zaštita Martinske crkve. [War Stops Works: Protection of St. Martin's Church.] Dugoselska kronika, No. 319, p. 6.

Haleuš-Mali, Nenad 1992a. Nemila sudba dugoselske crkve. [The Tragic Fate of the Dugo Selo Church.] Dugoselska kronika, No. 325, p. 7.

Haleuš-Mali, Nenad 1992b. Dočekali smo radove na Martinskoj crkvi. [At Long Last Work Starts on St. Martin's Church.] Dugoselska kronika, No. 326, p. 1.

Haleuš-Mali, Nenad 1992c. Skrb za svetoga Martina. [Caring for St. Martin.] Dugoselska kronika, No. 328, p. 8.

Haleuš-Mali, Nenad 1992d. Hocee li stati obnova sv. Martina. [Is the Reconstruction of St. Martin's about to Halt.] Dugoselska kronika, No. 329, p. 12.

Hameršak, Marijana \& Pleše, Iva \& Vukušić, Ana-Marija (eds.) 2013. Proizvodnja baštine: kritičke studije o nematerijalnoj kulturi. [Heritage Production: Critical Studies in Intangible Culture.] Zagreb: Institut za etnologiju i folkloristiku.

Handler, Richard \& Linnekin, Jocelyn 1984. Tradition, Genuine or Spurious. Journal of American Folklore, Vol. 97, No. 385, pp. 273-290. http://dx.doi.org/10.2307/540610. 
Hannam, Kevin \& Knox, Dan 2011 [2010]. Understanding Tourism: A Critical Introduction. London \& Thousand Oaks \& New Delhi \& Singapore: Sage Publications.

Kirshenblatt-Gimblett, Barbara 1998. Destination Culture: Tourism, Museums, and Heritage. Berkeley \& Los Angeles \& London: University of California Press.

Kozić, Nada 2007. Templari u kulturno-turističkim pohodima. [Templars in Cultural Tourism Campaigns.] Dugoselska kronika, No. 492, p. 1.

Martinska 1988 = Martinska crkva - smetlište. [St. Martin's Church: A Junkyard.] Dugoselska kronika, No. 284, p. 12.

Martinska, Martina 1994. Martinizacija. [Martinisation.] Dugoselska kronika, No. 338, p. 12.

Načinimo 1990 = Načinimo dugoselski božićni ugođaj. [Let Us Create the Dugo Selo Christmas Atmosphere.] Dugoselska kronika, No. 309, p. 12.

Nastavlja 1995 = Nastavlja se svetomartinska povijest. [The History of St. Martin's Continues.] Dugoselska kronika, No. 351, p. 1.

Oživljen 1992 = Oživljen duh Martinja. [The Spirit of Martinmas Reawakened.] Dugoselska kronika, No. 331, p. 1.

Povratak 1995 = Povratak Martin Bregu. [A Return to Martin Breg.] Dugoselska kronika, No. 348, pp. 6-7.

Remenar, Nevenka 2013. Priče mega detinstva: Martinje. [Stories of My Childhood: Martinmas.] Dugoselska kronika, No. 572, p. 10.

Službeni 1993 = Službeni glasnik općine Dugo Selo. [Official Gazette of Dugo Selo Municipality.] Dugoselska kronika, No. 337, p. 1.

Svetkovanje 1992 = Svetkovanje Svetog Martina. [Celebrating St. Martin.] Dugoselska kronika, No. 330, p. 1.

Timothy, Dallen J. 2011. Cultural Heritage and Tourism: An Introduction. Bristol \& Buffalo \& Toronto: Channel View Publications.

Zaradija Kiš, Antonija 2004. Sveti Martin: Kult sveca i njegova tradicija u Hrvatskoj. [Saint Martin: The Saint's Cult and its Tradition in Croatia.] Zagreb: Institut za etnologiju i folkloristiku.

Žuta 1992 = Žuta jesen i kruh svagdašnji: Radovi učenika Osnovne škole Dugo Selo. [Yellow Autumn and Daily Bread: Works by Pupils of Dugo Selo Elementary School.] Dugoselska kronika, No. 330, p. 7. 


\title{
THE AGE-OLD COSSACK FEAST OF THE PROTECTING VEIL: A CONTEMPORARY INTERPRETATION OF A TRADITIONAL CALENDAR DATE
}

\author{
Nina Vlaskina
}

\begin{abstract}
The article analyses the history and content of the modern Cossack celebration of the Feast of the Protecting Veil (Rus. Pokrov) of the Mother of God. The members of the Cossack movement call it the main Cossack national holiday. The article discusses the reasons and historical basis for such a characterisation of the celebration, and systematises its components that have emerged during different historical stages, using a wide variety of sources: ethnographic research articles, periodicals, Internet blogs and forums, as well as unpublished archive materials. The contemporary Cossack festival of the Protecting Veil combines the traits of the Host holidays and civil funerals, and pursues primarily etiquette objectives: particularly the confirmation of the succession of the status upwards from the prerevolutionary Cossacks to the modern ones, updating cultural values in a new environment. To achieve these goals, the organisers use universal components that have no time constraint and actively appeal to different layers of historical memory.
\end{abstract}

Keywords: calendar rites, contemporary feasts, Cossacks, identity, Russia, the Protecting Veil of the Mother of God

In modern Russia one of the issues under discussion is that of identity (civil, religious and ethnic). There are several reasons for it, including change of boundaries and composition of the federal administrative units in 1991, the return from state atheism to Orthodoxy, and worldwide trends of globalisation. For such a population group of Russia as the Cossacks, the question of identity turns out particularly complex.

In the early stage (15th-17th centuries) the Don Cossack community was made up of different ethnic groups (with a Russian majority), who settled in the southern outlying districts of the Russian state. The economic-cultural type of community in this period can be defined as 'war and hunting'. There were certain preconditions for a new ethnic group to be formed, with such features of spiritual culture as the rejection of cultural values of agricultural 
Slavs; the transformation of life-cycle rituals; the emergence of the horse cult and appearance of the original initial rite; the development of special laws; the deployment of military and democratic forms of community life organisation (selectivity and inter-changeability of leaders, the circle as a form of participation of all community members in the decision making process, etc.) (Protsenko 1998: 82).

As a result of Peter the Great's reforms, at the beginning of the 18th century, the process of ethnogenesis in the Don region was interrupted and the Russian government consistently pursued a policy of conversion of the Don Cossacks into a military estate of the Russian Empire.

Soon after the October Revolution of 1917, all estates (the nobles, the merchants, the petty bourgeoisie, the Cossacks, and others) were cancelled. Accordingly, the Cossacks underwent another change of status. After the collapse of the Soviet Union, the Cossacks have reaffirmed their rights and begun to discuss the question of identity: whether they are an estate or a nation. To strengthen their position both in the political arena and in the public consciousness, they invent some practices and along with it attribute new meanings to existing cultural forms. It is well known that many local traditions extensively use holidays in this function.

In this article, I have selected for the analysis the history and content of the modern Cossack celebration of the Feast of the Protecting Veil of the Mother of God. The members of the Cossack movement call it the main Cossack national holiday. The following step will be to discuss the reasons and historical basis for such a characterisation of the celebration, and to systematise its components that have emerged during different historical stages.

Below I will analyse the history of the traditional Cossack celebration of the festival, the differences between the content of the calendrical rituals and popular beliefs of the Cossacks and those of other groups of Russians, Cossack civil funerals as an official event, and festivals of the Cossack hosts (armies). This allows me to describe more precisely the content and axiological dominants of the contemporary Feast of the Protecting Veil.

In order to conduct a diachronic analysis, it was necessary to use several groups of sources: descriptions of the Cossack holidays in the 19th century, published in the periodicals and in the ethnographic research by M. Kharuzin (1885), Cossack emigrant journals and books from the mid-20th century, Internet blogs and forums, and also field materials of ethnolinguistic and dialect expeditions of the Southern Federal University (previously known as Rostov State University) and the Institute of Social-Economic Research and Humanities of the Southern Scientific Centre of the Russian Academy of Sciences, both separate and joint. 


\section{THE HISTORY OF THE CELEBRATION OF THE PROTECTING VEIL}

The Day of the Protecting Veil of the Mother of God (October 1(OS) / 14(NS)) is an Orthodox holiday that was established in memory of the vision of the Mother of God to St. Andrew the Fool-for-Christ in Blachernae church in Constantinople. The Mother of God stretched out her protecting veil over the besieged city and the people (Hagiography 2004: 5-6). The holiday was established on the territory of the Kiev province, and therefore remained virtually unknown to other churches, except Russian, or appeared there as a result of Russian influence. The intercession of the Blessed Virgin Mary, her patronage and shrouding as the basic ideas of the holiday, were grasped in the folk traditions of the Eastern Slavs (Agapkina 2009: 27).

The Feast of the Protecting Veil falls on the middle of autumn, and, owing to this, in the Russian folk calendar it marks the transition to winter and also the beginning of the wedding period, which was interrupted for the time of field work (ibid.).

In the Don region the folk motifs of the holiday associated with the end of the agricultural year are not as popular as in the central and northern regions of Russia, due to the natural conditions, namely the later onset of winter. In Central Russia the last pasturing of cattle was timed for the Feast of the Protecting Veil, whereas in the south of Russia cattle could be grassed until December. Russians in the regions further to the north believed that it was time for the ground to be covered with snow, whereas Cossacks regarded the fall of snow on this day as a sign of a severe ${ }^{1}$ or 'rotten' (rainy) ${ }^{2}$ winter. Isolated instances of preparation for the winter season (storing up hay and coal, washing and puttying windows) can be found in the materials from the Russian-Ukrainian borderlands, ${ }^{3}$ and a practice of planting garlic on this day was once recorded in the central part of the Don area. ${ }^{4}$ It should be noted that in the Don region agricultural rites in general have been preserved in a much reduced form (Gnutova \& Protsenko 2004: 48), because of the military service as a major form of the Don Cossack activity, as well as the migratory type of culture.

Marital motifs constitute the core of the Don Cossack beliefs about the Feast of the Protecting Veil. This day was the boundary around which matchmaking rites or weddings were concentrated. The proverb "The Protecting Veil comes, the maid roars like a cow", describing the sorrow of a girl who failed to become engaged that year, is widespread in the Don area.

Field data do not provide us with information about any sorts of social activities timed for this date, except for the places where churches were consecrated 
in the name of the Protecting Veil of the Mother of God, and therefore this day was a patronal festival.

Besides, there were civil celebrations timed for October. On December 24, 1890, Russian Emperor Alexander III issued his Decree No. 32, establishing October 17 as a special official day for the Don Cossack Host. This day was marked in the text of the decree as the day of a miraculous escape of the regnant family, threatened by a dangerous crash of the imperial train in 1888 , and the memory of prophet Hosea. October 1 was established as an officially celebrated holiday of all Cossack hosts. Henceforth, having become a civil event, the feast had much in common with other city holidays in different Russian territories regarding special organisers and a rather detailed scenario. In 1904, Imperial Decree No. 547 (issued on October 15) moved the military celebration of the Don Host to October 5, which was the name day of Prince Alexei, the august ataman of all Cossack hosts. The holiday was returned to an earlier date in August 1917 by African Bogaevsky, who was the chairman of the All-Great Don Host Government. After the Civil War the holiday was not celebrated in Soviet Russia, and the Cossack hosts were dissolved, as mentioned above. Thus, the tradition to celebrate the Host Day in October only existed for less than 30 years of all the four hundred years of the Don Cossacks' history.

We should also note here that the Civil War period was characterised by a surge of nationalist sentiment among the Cossacks. Disintegration processes in the Cossack regions of southern Russia led to the emergence of political entities which claimed an official status. When it was necessary to strengthen the status of the Cossacks and their territorial claims, the very idea of the Host Day performed an important integrating and stabilising function.

According to an eyewitness of the festive actions, a Cossack emigrant S. Boldyrev (1949), the chronology of the Host Day in Novocherkassk in 1918 lined up as follows. First the ataman inspected the troops participating in the parade, and then they carried the Cossack regalia out, including horsetails as symbols of authority, church banners, charters of kings and emperors, which were granted to the host for the age-old service and loyalty to Russia, etc. The next element of the celebration was the service performed in the cathedral, after which the icons and church banners were taken to the square. Next, the gunfire ceremony was performed, the parade of Cossack military units was held, and a common meal ('the host's bread and salt') was organised. At dinner the army orchestra played and the army choir in blue garments sang old songs.

In the 1920s, after the defeat of the White movement, many of the Cossacks were forced to leave Russia. In exile, due to the consistent emphasis on the national specificity of the Cossacks, the Host Day acquired additional meanings. 
Researchers of the dynamics of traditional cultures demonstrate that historical events play a crucial role in constructing and reconstructing rituals and techniques (Hobsbawm 1983: 4). Irina Sedakova (2008) and Victoria Popova (2008) have presented modern Russian holidays from this point of view. Inventors of new traditions provide feasts with a mythological aura to strengthen their position in the public mind (Popova \& Shumikhina 2008).

Different texts associated with the Feast of the Protecting Veil illustrate this trend. Some Kuban sources date the Cossack origin back to ancient times and consider the Cossacks to be present at the miraculous appearance of the Mother of God in the Blachernae church. They say that "this event was engraved in the memory of Cossack ancestors for a thousand years" (The Festival of the Host 1931: 2).

In many cases, the history of the Host Day can be traced back to the mythologised event of the miraculous appearance of Our Lady before the praying Cossacks in Azov town besieged by the Turks on the Feast of the Protecting Veil in 1641. The defence, embodying the symbolic meaning of the icon and the feast, correlated with the Cossacks' function of defending the Russian boundaries. According to an emigrant's article published in 1981, since then the Feast of the Protecting Veil has become not only a church festival but also a great all-Cossack festival (Protecting Veil 2012).

The authors of the Cossack dictionary published in the United States in 1966-1970 pointed out that the public liturgy was performed near Starocherkassk, on the site of the former monastic settlement, "annually, on the first day of October, on the Feast of the Protecting Veil, as a sign of honouring their ancestors, namely the Cossacks, who were killed during combat encounters with the enemy, and as a prayer for their souls" (Skrylov \& Gubarev 1992: 111).

Indeed, prior to the $1880 \mathrm{~s}$, worship of the dead Cossacks was annually conducted on the abovementioned site. However, it was carried out not on the Feast of the Protecting Veil, but in the Pancake week (in spring) (Popov 1905: 5). A similar funeral service in similar terms took place in Stanitsa (village/rural locality) Luganskaya (Kharuzin 1885: 384). It corresponded to the traditional terms of commemoration of the faithful departed (Agapkina 2002: 44).

The fact is that the denomination of the Feast of the Protecting Veil as an all-Cossack festival has little ground. The 19th-century sources give us no evidence of celebrating the Feast of the Protecting Veil or holding funeral services on this day. Thus, emigrant materials ascribed the status of the Host Day to a wrong holiday, and they named it universal, ubiquitous and existing from time immemorial, while the civic festivals of the Hosts had quite a peculiar history and a limited time frame of existence. 
The process of the Cossack revival, which began in the 1990s, required ideological support. The emigrants' works, whose status improved, inter alia, because they had been hidden from the general reader for a long time, were used in this capacity. It is the in-exile version in which the Cossack Host Day was restored. The texts generated by the representatives of the modern Cossack community call the Feast of the Protecting Veil just an original Cossack holiday. ${ }^{5}$

At the state level, civil events timed for this day were established by including the Feast of the Protecting Veil of the Mother of God in the list of the annual cultural mass events of a regional value (in 1988), and later on (in 2001) by setting the annual Memorial Day or the Day of Cossack Glory on the last Saturday before the Feast of the Protecting Veil.

The need to increase the importance of the Host Day, just as it had happened earlier, led to the actualisation of the memories of historical events, connected with this day one way or another. It is significant that in the modern mass media no one remembers the role of Alexander III and African Bogaevsky in establishing the days of the Cossack Hosts. I see the influence of the emigrants' views in the fact that modern Cossacks identify the Host Day with the Feast of the Protecting Veil. Most often they refer to the appearance of the Virgin before the Cossacks who defended Azov against the Turkish attack in $1641 .^{6}$ Less common are other facts, such as gratitude, declared by Field Marshal Kutuzov to Cossacks in $1812 .^{7}$

The combining of several festive occasions probably also serves the purpose of improving the status of the holiday. It becomes possible due to the parallel existence of different calendars (the civilian - both on the state and regional level - and the ecclesiastical one). The Feast of the Protecting Veil can be merged with the Farmers' Day, the Day of the Recruit, and the Day of the Village. It should be noted that in many communities the Day of the Village replaced the Patron Saint's Day in the Soviet era, and many churches of the Don region were consecrated to the Protecting Veil of the Mother of God.

In 2012, the activities of the Cossack communities were timed for the Feast of the Protecting Veil and for the 200th anniversary of the victorious participation of the Don Cossacks in the Patriotic War of $1812 .^{8}$

\section{THE CONTENT OF THE MODERN COSSACK FEAST OF THE PROTECTING VEIL}

Today we are witnessing the transformation of the calendar date perception. The Feast of the Protecting Veil enhances its status due to the fact that the Host Day is considered to be timed for it, and after that a change of emphasis 
takes place, and the Feast of the Protecting Veil turns from the Cossack Host Day into a primordial Cossack feast.

Below I will examine the content of the modern Cossack Feast of the Protecting Veil.

The first component is a festive service in the church or a memorial service for the dead Cossacks in the field, related to the historical events in the life of the Cossack Host. The content of this component has not undergone any significant changes, as it is probably highly regulated. However, its perception has changed. As already mentioned, the Protecting Veil memorial service on the site of the former monastic settlement was declared to be much older than it really was. The fact that neither field records nor mass media materials give us evidence of a local ritual practice in the Don region, connected to the icon of the Protecting Veil, may testify to the idea that rapt attention to this feast as very important for the Cossacks has no deep roots and has appeared only recently.

The second component is the parade, exercises, and demonstration of military skills (horse racing, fancy riding, slashing). According to ethnographic sources, these were characteristic elements of Cossack holidays in the 19th century (Timoshchenkov 1873). In addition to the manifestations of daring and the integrating function, these exercises also had a pragmatic meaning, namely, the training of young Cossacks for military service, as all these skills were needed in combat. As a part of today's celebrations timed for the Feast of the Protecting Veil, they are preserved in a form close to the old one, or can be transformed into a competition of reenactors.

Under the name 'the Cossack Saviour', or 'national games of the Cossacks' (Shermitsii) they have moved into the category of ethnic sports (one of the founders of the Shermitsii is the All-Russian Federation of Ancestral Fun and Russian Ethnosport). The announced aim of these actions is the preservation of historical roots, values and traditions of the Cossacks, but the organisers have not commented on the change of the historical context and lack of demand for these kinds of skills, and thus the strengthening of the entertainment and gaming dominance of the event.

Public meals, being known to many people as a mandatory attribute of a holiday tradition that has constitutive and consolidating functions, are supplemented or replaced by modern forms of leisure: master classes (how to cook Cossack fish soup), ${ }^{9}$ tastings (field kitchen, so-called soldier's porridge),${ }^{10}$ which leads to a change in the function of this element. Having soldier's porridge as a ritual meal on a number of occasions shows a trend towards the universalisation of ritual forms. Not so long ago, tasting soldier's porridge became an integral component of celebrating the Day of Victory in the Great Patriotic War of 1941-1945, in which it has primarily the commemorative function. 
The mechanical transfer of ritual meals into a series of activities timed for the Feast of the Protecting Veil erodes the meaning of the holiday, partly because in pre-revolutionary Russia, whose festive regulations appeal to those reviving the Host Day, soldiers and Cossacks were countered both on the official level (regular and irregular troops) and as a stereotype (ordinary men - the Cossacks).

Finally, the organisers include the universal forms in the list of festive activities which were the most widespread in the Soviet period: an award presentation (prominent people in agriculture, the best Cossack squad), a concert given by folk groups, games and competitions (including the best performance of Cossack cadet songs, and the best camping cooking of Cossack meals).

An interesting fact is that the name and semantics of the festival can be used with respect to the activities carried out under other terms. For example, in 2011, the so-called Cossack national games timed for the Feast of the Protecting Veil were held on the Day of the Nativity of the Mother of God and, therefore, were simultaneously linked by the organisers to the two traditional calendar dates. Apparently, this fact was to testify to the high level of religiosity of the Cossacks. In April of the same year, the International Festival of Cossack folklore groups under the heading The Protecting Veil on the Don (Festival 2011) was held in the Millerovsky district of the Rostov region (where most of the population are non-Cossack). The correlation between festivities and the agrarian or the professional year cycle has disappeared. By the words of Jeremy Boissevain, "hence, when they [the feasts] are celebrated is now a matter of convenience" (Boissevain 2013: 206).

Thus we see that the content of the so-called 'Cossack' feast involves some elements typical of many European festive scenarios. Church services or masses and common meals are an integral part of patronal feasts. Sport activities and various competitions have also often been connected with local festivals (especially recently) (Fournier 2007).

Elements of different historical layers are mixed and transformed in the analysed celebration to achieve the central aim of demonstrating the Cossack specificity. The very idea to label this feast as a Cossack one could be interpreted as a way to accentuate their presence in the ritual year. Different objects and practices gain the 'Cossack' attributes throughout all festive activities. Men often attend a church service on the Feast of the Protecting Veil, wearing the Cossack uniform. The re-enactment named Shermitsii is presented as a revitalised old Cossack tradition. In fact, it is a kind of restored or resurrected practice (Boissevain 2013: 202), to put it more precisely. Old Cossack training exercises were introduced and organised in a form of periodical games by educated men elaborating the issues of Russian traditional sports. They use new materials (e.g. plastic bottles with water instead of streams of water or thick sticks) and 
modern sportswear. In addition to various forms of competition, organisers include different kinds of exams in the programme of the Shermitsii to test the knowledge of the Cossack rituals and beliefs. As was mentioned above, the food cooked for the feast may be characterised as typically Cossack.

The practice of the Cossack celebration of the Feast of the Protecting Veil represents the way that an ethnic or social group can manifest its interests within the framework of the ritual year. The modern content of the analysed feast absorbs several symbolic meanings and includes elements from different historical layers:

1. An Orthodox holiday and a Slavic traditional feast marking the symbolic border between autumn and winter seasons;

2. A practice of annual worship of the Cossacks killed in action;

3. Officially celebrated October feasts of all Cossack hosts and of the Don Cossack Host in the pre-revolutionary period.

In the 20th century the Cossack emigrants provided the Feast of the Protecting Veil with a long mythologised history, and throughout several decades the members of the modern Cossack movement have adopted these ideas, and now they widely celebrate 'the age-old Cossack Feast of the Protecting Veil'. ${ }^{11}$ So, the Cossack activists turned one of the Slavic traditional feasts into a vehicle for strengthening their position in the political and local scene. The motive for choosing this holiday to promote Cossack interests was the notion of defence, which is one of the meanings of the icon and also the main function ascribed to the Cossacks as a former estate of the Russian Empire. The objective of the festivity organisers is the confirmation of the succession of the status from the prerevolutionary Cossacks to the modern ones, as well as updating of cultural values in a new environment. To achieve these goals, they exploit universal components that have no time constraint, and actively appeal to different layers of historical memory.

\section{ACKNOWLEDGEMENTS}

This article is part of a collective basic research project of the Institute of SocialEconomic Research and Humanities SSC RAS (2013-2015), titled Istoricheskie formy $i$ sovremennye sposoby funktsionirovaniia sotsiokul'turnykh institutov na Iuge Rossii (Historical Forms and Modern Ways of Functioning of the SocioCultural Communities in the South of Russia). 


\section{NOTES}

1 Folder 23, 2000, Zimovnikovsky district of the Rostov Region; folder 27, 1999, Konstantinovsky district of the Rostov Region; folder 77, 2003, Tarasovsky district of the Rostov Region. Manuscript Archive, Chair of General and Comparative Linguistics, Southern Federal University.

2 Folder 72, 2003, Azovsky district of the Rostov Region. Manuscript Archive, Chair of General and Comparative Linguistics, Southern Federal University.

${ }^{3}$ Folder 77, 2003, Tarasovsky district of the Rostov Region. Manuscript Archive, Chair of General and Comparative Linguistics, Southern Federal University.

4 Folder 98, 2009, Morozovsky district of the Rostov Region. Manuscript Archive, Chair of General and Comparative Linguistics, Southern Federal University.

5 Rossiiskomu kazachestvu posviashchaetsia. Informatsionnyi portal: Ot kazakov TsKV vsem brat'iam-kazakam: s Prazdnikom, Braty-Kazaki. [Dedicated to the Russian Cossacks. Informational Portal: From the Cossacks of the Central Cossack Host to All Brothers-Cossacks: Congratulations, Brothers-Cossacks.] October 8, 2013. Available at http://kazachestvu.ru/kazaki/1109, last accessed on January 26, 2015.

6 Donskaia Zimovaia stanitsa: Obshchevoiskovoi kazachii prazdnik Pokrova Presviatoi Bogoroditsy. [Don Zimovaya Stanitsa: The Cossack Feast of All the Hosts of the Protecting Veil of the Mother of God.] October 4, 2012. Available at http://www. zimovaya.ru/novosti/obschevoyskovoy-kazachiy-prazdnik-pokrova-presvyatoybogoroditsy-3.html, last accessed on January 26, 2015; Vol'naia stanitsa: Otchego prazdnik Pokrova Bozhiei Materi tak berezhno chtitsia kazakami? [Free Stanitsa: Why is the Feast of the Protecting Veil of the Mother of God Honoured by Cossacks with Such Care?] Not dated. Available at http://fstanitsa.ru/category/menyu/vera/otchegoprazdnik-pokrova-bozhiei-materi-tak-berezhno-chtitsya-kazakami, last accessed on January 26, 2015; etc.

7 ITAR-TASS: Uchastniki konnogo pokhoda Moskva - Parizh otmetili glavnyi kazachii prazdnik - den' Pokrova Presviatoi Bogoroditsy. [The Members of the Horse March Moscow-Paris Celebrated the Main Cossack Feast - the Day of the Protecting Veil of the Mother of God.] October 14, 2012. Available at http://www.prazdnikmedia.ru/ archive/news/article/126859, last accessed on January 26, 2015.

8 Informatsionnyi portal Konstantinovsk.ru: Shermitsii v Pukhliakovke. [Informational Portal: Shermitsii in Pukhliakovka.] September 21, 2012. Available at http:// konstantinovsk.ru/news/21-09-2012/shermitsii-v-pukhlyakovke, last accessed on January 27, 2015.

9 Kazachii Don: Kul'turno-istoricheskii turistskii kompleks. Prazdnik Pokrova Presviatoi Bogoroditsy "Kazachii Don". [The Cossack Don: Cultural-Historical Tourist Complex. The Feast of the Protecting Veil of the Mother of God "The Cossack Don"]. October 14, 2012. Available at http://казачийдон.pp//blog/reports/prazdnik_pokrova_presvyatoy_ bogoroditsy_kazachiy_don/, last accessed on January 27, 2015. 
${ }^{10}$ KAFANEWS. Krym: novosti Feodosii: Kazaki Feodosii nakormili kuleshom. [KAFANEWS. Crimea: The News of Feodosia: The Cossacks of Feodosia Fed People with Kulesh]. October 14, 2011. Available at http://kafanews.com/novosti/35015/kazakifeodosii-nakormili-kuleshom_2011-10-14, last accessed on January 27, 2015.

${ }^{11}$ Ot kazakov TsKV vsem brat'iam-kazakam: s Prazdnikom, Braty-Kazaki. [From the Cossacks of the Central Cossack Host to All the Brothers-Cossacks: Happy Holidays, Brothers-Cossacks.] October 8, 2010. Available at http://kazachestvu.ru/kazaki/1109, last accessed on January 27, 2015.

\section{REFERENCES}

Agapkina 2002 = Agapkina, Tat'iana. Mifopoeticheskie osnovy slavianskogo narodnogo kalendaria: Vesenne-letnii tsikl. [The Mythopoetical Basis of the Slavic Folk Calendar: The Spring/Summer Cycle.] Moskva: Indrik.

Agapkina 2009 = Agapkina, Tat'iana. Pokrov. [Feast of the Protecting Veil.] In: N. Tolstoi (ed.) Slavianskie drevnosti. Etnolingvisticheskii slovar'. T. 4: Pereprava cherez vodu - Sito. Moskva: Institut slavianovedeniia RAN, pp. 127-128.

Boissevain, Jeremy 2013. Factions, Friends and Feasts: Anthropological Perspectives on the Mediterranean. New York \& Oxford: Berghahn Books.

Boldyrev 1949 = Boldyrev, Sergei. Voiskovoi prazdnik. Vospominanie nedavnego proshlogo, posviashchaetsia svetloi pamiati donskogo atamana P. N. Krasnova. [The Festival of the Host: The Recollection of the Near Past, Dedicated to the Blessed Memory of the Don Ataman P. N. Krasnov.] Obshchekazachii zhurnal, No. 9, pp. 2-6. Available at http://elan-kazak.ru/sites/default/files/IMAGES/ ARHIV/Periodika/okzh/OKG-9-1949.pdf, last accessed on January 27, 2015.

Festival 2011 = Festival' "Pokrova na Donu" na Millerovskoi zemle. [Festival "The Protecting Veil on the Don" on the Millerovsky Land.] Newspaper Nash krai, April 9, p. 7.

Fournier, Laurent Sébastien 2007. Traditional Games and the Ritual Year in Provence (France): From Ludodiversity to Cultural Heritage. The Ritual Year and Ritual Diversity: Proceedings of the Second International Conference of the SIEF Working Group on the Ritual Year. Gothenburg, June 7-11, 2006. Göteborg: Institutet För Språk och Folkminnen Dialekt-, Ortnamns- och Folkminnesarkivet i Göteborg, pp. 183-190.

Gnutova \& Protsenko 2004 = Gnutova, Liudmila \& Protsenko, Boris. K izucheniiu donskoi kalendarnoi obriadnosti: prazdnovanie Novogo goda. [On the Issue of the Don Calendar Rites: The New Year Celebration.] Traditsionnaia kul'tura, No. 4, pp. 48-53.

Hagiography 2004 = Zhitiia sviatykh sviatitelia Dimitriia Rostovskogo. Tom 2: Oktiabr'. [Hagiography by St. Dimitry Rostovsky. Volume 2: October.] Kiev: Phoenix.

Hobsbawm, Eric 1983. Introduction: Inventing Traditions. In: Eric Hobsbawm \& Terence Ranger (eds.) The Invention of Tradition. Cambridge University Press, pp. 1-14. 
Kharuzin 1885 = Kharuzin, Mikhail. Svedeniia o kazatskikh obshchinakh na Donu. Materialy dlia obychnogo prava, sobrannye Mikhailom Kharuzinym. [Data on the Don Cossack Communities: Materials for the Common Law Collected by Mikhail Kharuzin.] Moskva: Tipografiia M. P. Shchepkina. Available at http://www. history-fiction.ru/books/all_1/user_4_1/region_110_10/section_1_1/sort_2_1_2/ book_230/, last accessed on January 27, 2015.

Popova \& Shumikhina 2008 = Popova, Viktoriia \& Shumikhina, Liudmila. Transformatsiia form prazdnichnoi kul'tury: igrovoi aspekt. [The Transformation of the Festive Activity Forms: The Gaming Aspect.] Izvestiia Ural'skogo gosudarstvennogo universiteta, No. 55, pp. 25-33.

Popov $1905=$ Popov, Khariton. Istoricheskaia panikhida na Monastyrskom urochishche. [Historical Service for the Dead in the Former Monastic Settlement.] In: Pamiatnaia knizhka Oblasti Voiska Donskogo na 1905 g. Novocherkassk: Oblastnaia v. D. tipografiia. Part 3, pp. 3-5.

Protecting Veil 2012 = Pokrov Bogoroditsy - prazdnik kazachestva. [The Feast of the Protecting Veil of the Mother of God as a Holiday of the Cossacks.] In: Konstantin Khokhul'nikov (comp.) Kazaki Rossii! Sbornik statei, ocherkov $i$ stikhov avtorov kazach'ego zarubezh'ia. Rostov-na-Donu: Donskoi Izdatel'skii Dom, pp. 361-363.

Protsenko 1998 = Protsenko, Boris. Etnolingvisticheskaia kontseptsiia proiskhozhdeniia i kharaktera dukhovnoi kul'tury donskikh kazakov. [The Ethnolinguistic Conception of the Origin and Nature of the Don Cossacks' Spiritual Culture.] Nauka o fol'klore segodnia: mezhdistsiplinarnye vzaimodeistviia. Tezisy mezhdunarodnoi nauchnoi konferentsii k 70-letnemu iubileiu Fedora Martynovicha Selivanova (Moskva, 29-31 oktiabria 1997 g.). Moskva: Dialog MGU, pp. 80-82.

Sedakova, Irina A. 2008. Inventing the Ritual Year in Modern Russia. The Ritual Year and History: Proceedings of the Third International Conference of the SIEF Working Group on the Ritual Year. Strážnice: Institute of Folk Culture, pp. 51-58.

Skrylov \& Gubarev 1992 = Skrylov, Aleksei \& Gubarev, Vitalii (eds.) Kazachii slovar'spravochnik. Reprintnoe vosproizvedenie izdaniia 1966-1970 gg. [The Cossack Reference Book. Reprint of the 1966-1970 Edition.] Tom 1. Moskva: TO “Sozidanie”.

The Festival of the Host 1931 = Voiskovoi prazdnik. [The Festival of the Host.] Kubanskoe kazachestvo: Istoriko-literaturnyi i illiustrirovannyi zhurnal. No. 1, pp. 1-4. Available at http://archive.org/stream/kubanskoekazache00obsh\#page/ n6/mode/1up, last accessed on January 27, 2015.

Timoshchenkov 1873 = Timoshchenkov, Ivan. Iz Kazanskoi stanitsy: Obuchenie maloletkov voennomu delu. [From Kazanskaya Stanitsa: Training of Young Cossacks for Military Service.] Donskie oblastnye vedomosti, No. 3, January 16, pp. 2-3. 


\title{
UŽGAVE்NE்S: A RURAL AND URBAN, RELIGIOUS, SOCIALIST, AND LITHUANIAN FESTIVAL OF SHROVETIDE
}

\author{
Žilvytis ড̌aknys
}

\begin{abstract}
The article uses the case of Užgavenès (Shrovetide) to reveal how the content of a festival can shift over time. It discusses how festival associated with agricultural calendar can acquire a religious character and become a youth, urban, socialist, national, and ethnic festival, can be used not only for recreational purposes but also ideological ones in the fight against religiousness and an attempt to create a socialist festival, and, at the same time, to nurture Lithuanian culture. The newly created image of Užgavènès as a rite of passage - a festival marking a turn of season - has determined its recent fate and even given it greater significance. It has also spread in Lithuanian communities abroad, forming a temporary deterritorialised Lithuanian ethnic cultural space, allowing them to feel 'back at home' in each other's company, and to maintain their ethnic identity.
\end{abstract}

Keywords: ethnic identity, festival, ideology, Lithuania, religion, socialism, Užgavènès (Shrovetide)

\section{INTRODUCTION}

In the Republic of Lithuania the day of Užgavènès (Shrove Tuesday ${ }^{1}$ ) is an ordinary working day. Yet, it is also a great festival. This festival is celebrated either on the traditional day (Tuesday) or moved to the preceding weekend (Saturday or Sunday) in different localities throughout Lithuania. Mass events already start on Saturday. For example, in Vilnius in 2013, the Vilnius Ethnic Culture Centre organised an Užgavènès celebration based on the tradition of the Samogitian ethnographic region ${ }^{2}$. The following description was presented in the event's programme:

The merry uproar of costumed processioners in the city of Vilnius begins already during the day. At about nightfall, the masked characters - a Bear, a Crane, a Rider on a horse, a Death, a Goat, and a Doctor, as well as Gypsies $^{3}$, Hungarians ${ }^{4}$ Jews $^{5}$, beggars, devils, witches, Lašininis (Porky) ${ }^{6}$ struggling with Kanapinis (Hempen Man) ${ }^{7}$ and Morè, which is the spirit 
of the devilish, overstayed winter, and is borne on a runner or a wheel, gather to burn the symbolic effigy of More ${ }^{8}$ and drive out winter. When all of the masked processioners, squealing with joy around a bonfire, burn More and coloured flames shoot into the sky announcing the end of winter, Kanapinis wins the struggle with Lašininis and 'drives him out' until Easter. A great deal of fatty and filling food and traditional pancakes ${ }^{9}$, symbolising the primeval sacrifice of bread, are eaten during the festival. (Užgavènès Vilniuje! Renginių programa)

The actual Užgavènès day (Tuesday) is much quieter, yet many festival events take place and the city abounds in masked children and adolescents. Children also celebrate at schools. In 2013 even the President of the Republic of Lithuania, Dalia Grybauskaitè, visited one of the festival events and met pupils of Žvèrynas Gymnasium on this day. The country leader watched the battle between Lašininis and Kanapinis, set the effigy of Morè on fire, danced national dances, and tasted traditional pancakes (Prezidentè D. Grybauskaitè 2013).

Traditionally, the people returning from work at about sundown receive unexpected guests: several groups of costumed, masked, or painted children and adolescents chanting the traditional formula: "We, Gypsies (or Jews) of Lithuania, request pancakes and coffee; if you have no pancakes, please dig out some money". Children are usually cheered to receive several coins but are also satisfied with sweets, fruits, or pancakes. The festival is celebrated in a similar manner all over Lithuania.

The Open Air Museum of Lithuania in Rumšiškès, which is called the Užgavènès Capital, attracts the most participants. ${ }^{10}$ In general, this festival has a far less commercial nature in Lithuania than Christmas, Easter, or Midsummer, but it is still celebrated wholeheartedly, not only by the inhabitants of Lithuania and foreign tourists (especially young people), but also by Lithuanians living abroad.

Considerable significance is attached to Užgavenès in Lithuanian communities abroad: in Ireland, Belarus, Belgium, Canada, Denmark, Estonia, Greece, Spain, the United Kingdom, the United States, Canada, Latvia, Poland, Luxemburg, France, the Russian Federation, Finland, Sweden, Switzerland, Ukraine, Hungary, and Germany, i.e., in 22 of the 39 states in which Lithuanian communities officially exist. In these 22 countries Lithuanians celebrate Užgavėnès, often calling it a 'Lithuanian' festival. How did Užgavènès, a festival associated with agricultural calendar, become a festival uniting Lithuanians around the world? This article is an attempt to answer this question and to reveal the transformation of this festival's content over time. 
The main source for this article is materials of ethnographic fieldwork on the ritual year of young people. I also participated in projects, the aim of which was to compile data for an atlas of Lithuanian traditions. The conducted research can be divided into several stages.

During the first stage (1988-1995), about 250 localities were explored by surveying local people born prior to 1920, using the semi-structured interview method. The interviewees were requested to tell about the customs that had existed in their youth. Fieldwork was also undertaken in Lithuanian communities located near the border of the Republic of Lithuania in Poland, Latvia, and Belarus (Šaknys 2001a). During these explorations, data were compiled about the Užgavènès customs in 1910-1940.

During the second investigation stage (2002-2009), young people, most of them aged 16-25, were questioned about the present-day festival, using semistructured interview and observation methods. The fieldwork included 150 localities. Investigations of present-day youth customs were also conducted in Latvia (in 2000 and 2001) and Poland (2005). In an effort to comprehend the specific features of urban culture, investigations of youth customs were also conducted in Lithuanian capital Vilnius in 2005, 2007, 2008, 2012, and 2013. During this fieldwork, data were compiled about the situation in the early 21st century. During the entire fieldwork period, mainly Catholic (Evangelical Lutherans in the west of Lithuania, and Reformed Evangelicals in the northeast) Lithuanians were surveyed. Catholic Poles were frequent interviewees in southeast Lithuania and the city of Vilnius. Small numbers of Russian Old Believers, Belarusian and Russian Orthodox believers, and non-Christians were also interviewed, most of them in Vilnius.

The fieldwork was conducted on one or two-week expeditions with fixed itineraries, and on day trips in the city of Vilnius and in localities at a distance of up to $100 \mathrm{~km}$ from it.

It is fairly difficult to reveal the situation during the Soviet occupation on the basis of these fieldwork data. The creation of the new socialist calendar festivals was rather chaotic. The changing attitudes of the Soviet ideologists towards festivals and local initiatives caused diversity and rapid changes in these festivals. As the festivals that replaced Užgavėnès lacked clear symbols, the reconstructions of the festivals celebrated during the Soviet period, offered by people several decades later, were rather vague. Therefore published sources were mainly used in analysing the Soviet era festivals.

Meanwhile a more comprehensive investigation of the customs of Lithuanian diaspora has only begun; an analysis of the Užgavėnès festival celebrated in Lithuanian communities far from Lithuania is possible by using mainly internet sources. 


\section{UŽGAVĖNĖS, AN AGRICULTURAL FESTIVAL}

In the words of ethnologist Irena Regina Merkienè, traditional calendar rites are a component of agrarian culture. In Lithuania, these rites were affected by Christianity somewhat less than in other European nations and mainly reflect the experience of local farmers, animal breeders, beekeepers, and wild food foragers (Merkienè 2011: 173). The oldest data about Užgavėnès customs in the Balts' territories date back to the 15 th century. At a 1428 sermon, monk Heinrich Berinberger mentioned that in Lower Prussia "devil dances occur [---] during weddings and at Užgavènès, and respectable people allow women to dress in men's clothing, boyish coats, etc., which God has forbidden" (Vèlius 1996: 492). More detailed data about Lithuanian Užgavènès customs are available only from the sources of the 19th and early 20 th centuries. For example, Liudvikas Adomas Jucevičius in his 1842 Žemaičiu žemes prisiminimai (Recollections of the Land of the Samogitians) mentions having seen processions at Užgavènès in his childhood. He describes processioners dressed as Jews, Germans, Gypsies, and soldiers, and a straw figure paraded on a cart on Ash Wednesday and later burnt. According to the author, this ritual was probably performed in ancient times and had some mystical meaning (Jucevičius 1959: 448-449).

As Arūnas Vaicekauskas has noted, Central and Eastern European agricultural folk traditions have many common features. The main rituals of the calendar festivals are no exception. For example, the essential Užgavėnès festival rites in all of the region's cultures include processions of costumed village youths, parades with horse-pulled sledges, dragging around a straw figure or a block of wood, a cornucopia of food positively mandatory for all agricultural rituals, swinging on swings, and other (less meaningful) rites. The structure of the Užgavènès festival is essentially identical everywhere, but even such a comparatively small territory as that occupied by ethnographic Lithuania today has certain regional features: "In the east, southeast, and south of Lithuania the main emphasis of the Užgavènès rites was on riding in horse-drawn sledges, while in Samogitia (and partly in central Lithuania) costumed processions predominated" (Vaicekauskas 2010). A. Vaicekauskas has observed that Užgavènès does not have any feast status in the Catholic liturgical calendar and is today considered an ordinary day before the Lenten fast. Only in the traditional agricultural calendar does Užgavènès have all of the features of a large (annual) festival (Vaicekauskas 2005: 11). On the other hand, the fact that it is the last day before 46 days of abstention from meat and gaiety, has led to the festival's intensity and frequently motivated young people to participate, for one last time, in merry parties, and people of all ages to eat heartily meaty 
foods prior to the fast. For this reason, we cannot claim that Užgavènès festival had no connection with the religious calendar. This influence is not direct and is connected to the structure of the Catholic calendar. Užgavènès has been given similar significance by the Old Believer and Orthodox religions. Nevertheless, this connection with the Christian calendar was a sufficient pretext during the Soviet occupation to call Užgavènès a religious festival.

\section{YOUNG PEOPLE'S UŽGAVĖNĖS}

Besides the adults' community united by age, territory, and common interests, the agricultural society of the late 19th and first half of the 20th centuries featured a community of young people with definite autonomy. While the life of the adult community was connected by common economic ties and work, the territorial community of the young people was joined by leisure and recreation and the need to 'copy' and learn about adult life. The ritual year of the youth community was inseparably connected with agricultural and Christian religious calendars (̌̌aknys 1996: 105-115).

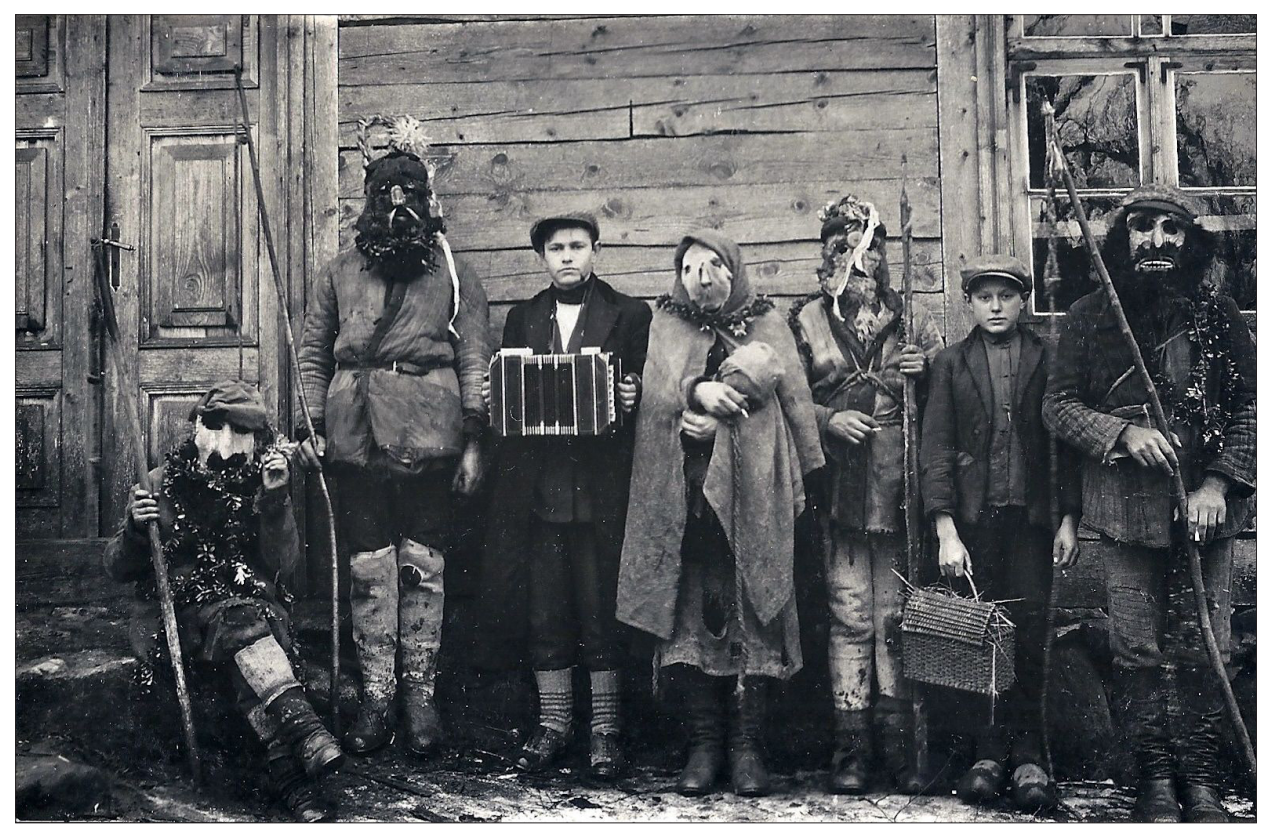

Figure 1a. Masked youth. Salantai, 1923. MFL 949. 
Žilvytis Šaknys

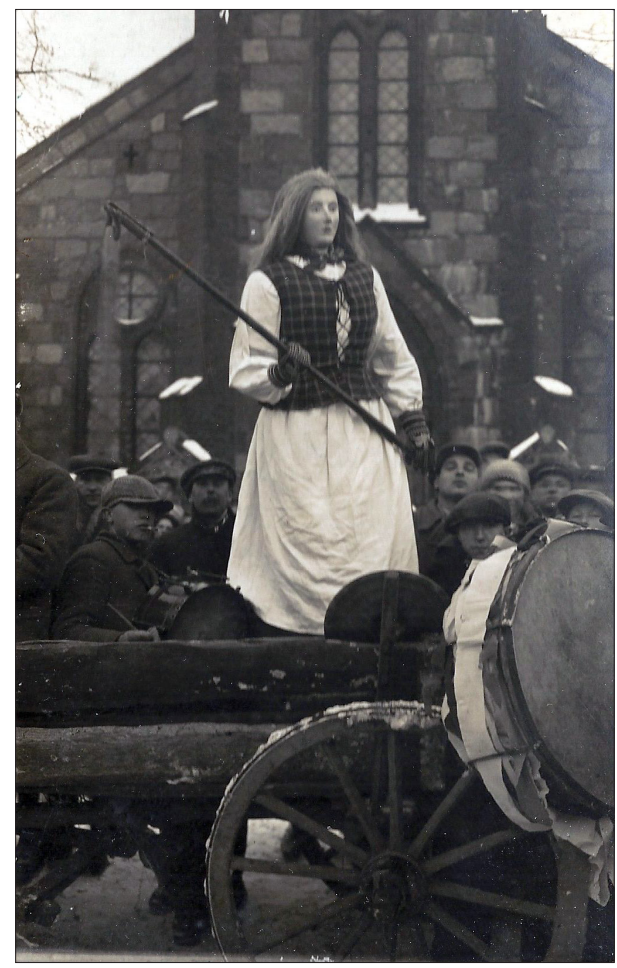

Figure 1b. Moré. Tubausiai, 1932. MFL 949.

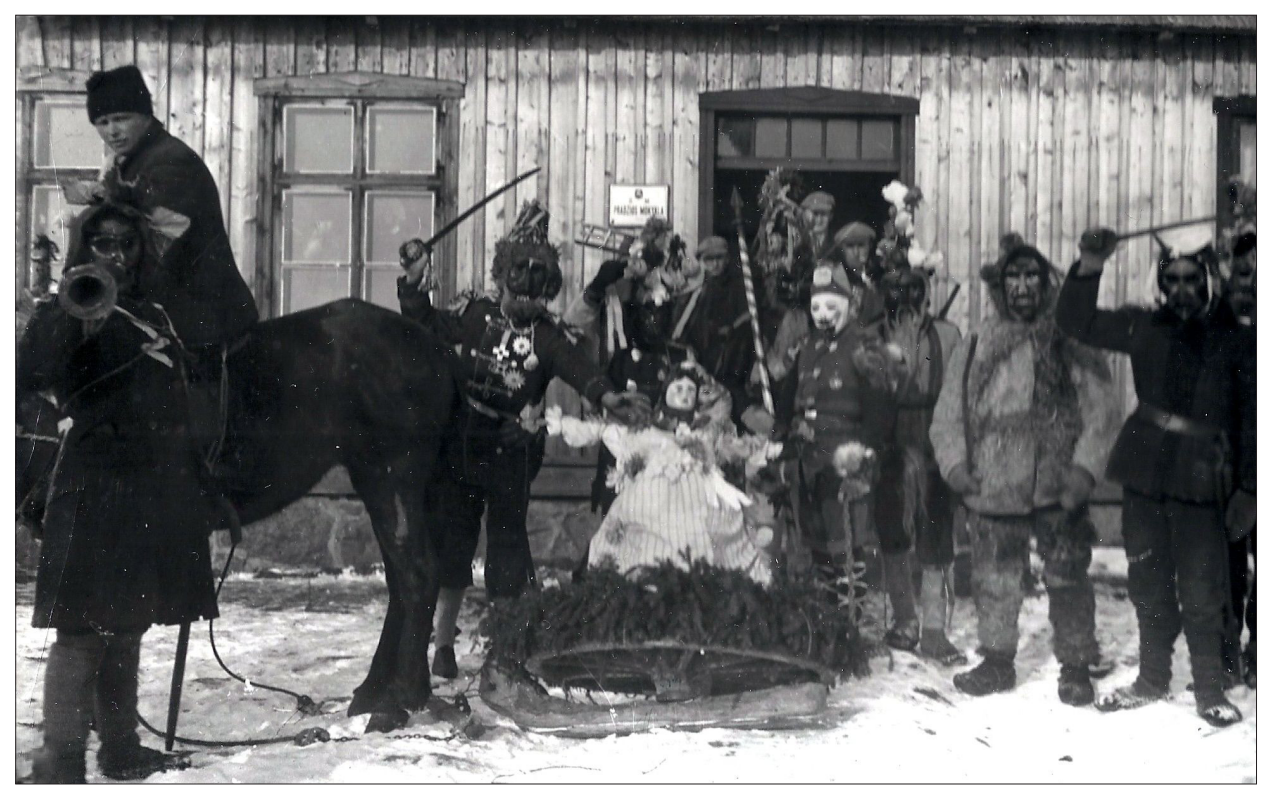

Figure 1c. Masked youth and Morè. Kurmaičiai, Kretinga district, 1933. MFL 949. 
Užgavėnès was a significant day for young people. Throughout almost all of Lithuania it was related to merrymaking. When asked during field research what Užgavenès meant to them, many of the respondents began with the phrase 'It is the last day before Lent', and usually continued by telling about the dances organised on this occasion. In eastern Lithuania they mentioned merry rides in sledges (the longer the slide, the longer the stem of flax next summer); in the west of Lithuania they mentioned costumed processions. Their motivation was to continue the traditions or just have a good time.

During the interwar period, merriment was organised in $76 \%$ of the studied localities. In $6 \%$ of the localities this did not end at the time decreed by the Church. The clock's hands were turned back or a rooster was hidden under a vat (as after midnight Lent began and it was forbidden to dance), and the merriment lasted until predawn. Užgavènès parties dominated in all of the Lithuanian ethnographic regions except Lutheran Lithuania Minor (Šaknys 2001a: 51). Somewhat more frequently festival merriment occurred only during the biggest holidays - Christmas, Easter, and Pentecost - and lasted 2-4 days, but it was organised more frequently at Užgavènès than New Year, Epiphany, Ascension, and Corpus Christi, even though these were public holidays (Šaknys 2001a: 82).

The custom of a costumed procession was connected not only with Užgavènès. In the first half of the 20th century Christmastide costumed processions were more widespread and marked by considerable diversity. A costumed procession at Epiphany was known all across Lithuania, a procession of boys dressed as biblical figures occurred in a specific region in the southwest of Lithuania, and the main role in the costumed processions in a small part of southern Lithuania was performed by a young man dressed as a horse, Šyvis (Silver). The custom of 'walking around like Gypsies' was widespread in northern Lithuania. Užgavėnès costumed processioners dominated in only one ethnographic region, Samogitia, occurring elsewhere in only isolated instances. The main role in these was performed by boys dressed as Jews; sometimes a procession of children acting like beggars was organised on the eve of the festival (Šaknys 2001a: 45, 51).

The experience acquired with age has special significance in an agricultural society and therefore the actions performed by the young people, in the majority of cases, can hardly be associated with important agricultural rituals. It is perhaps possible to connect the Užgavènès swinging or riding in sledges with these rituals (some of the people knew of the belief that this would improve the flax harvest), but L. Jucevičius, who grew up in Samogitia in the early 19th century (born in 1813) and investigated Samogitian customs in the first half of the century, was already unable to explain the meaning of dressing up in costumes. Respondents born in the late 19th and early 20 th centuries mentioned to only the recreational meaning. From the investigator's perspective it is possible to 


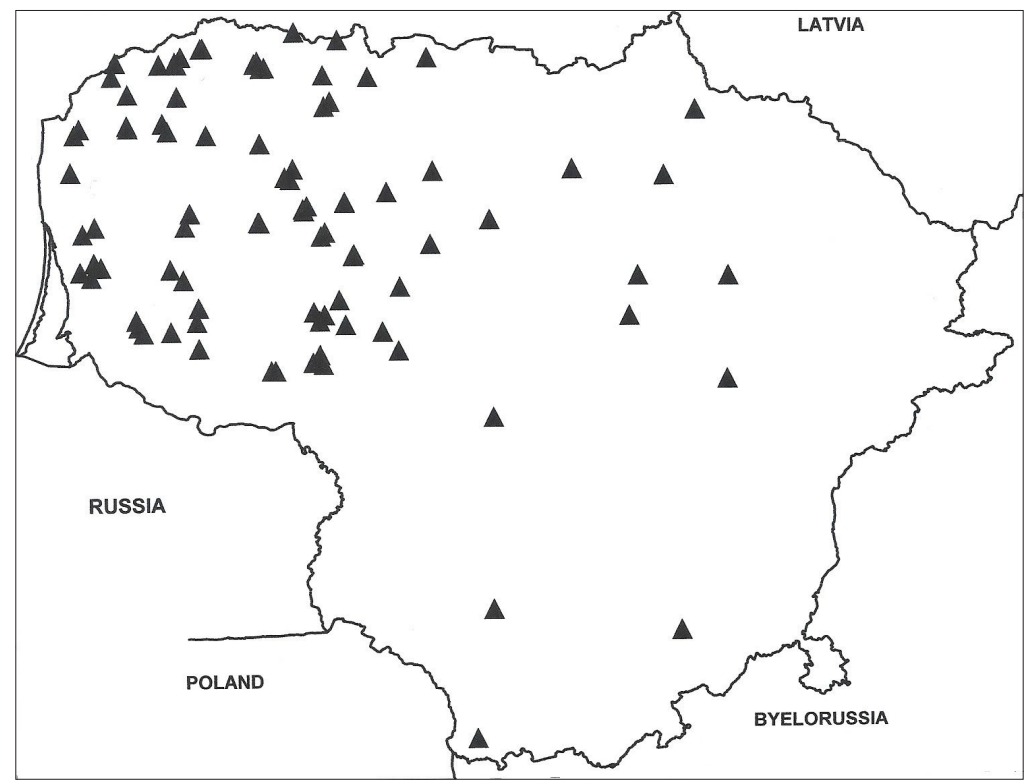

Figure 2. Youth outdoor fete at Užgavėnès (1920-1940) (Šaknys 2001a: 51).

reconstruct the ritual behaviour of the Užgavènès costumed processioners as paying special attention to girls. Like in other Western European countries, the Samogitian costumed processioners went to 'buy spinsters and barren women' (Lith. bergždininké, literally a barren animal), tested how fat they were, forced them to kiss the ground through their apron, jokingly sprinkled them with 'holy water', 'incensed' them with smoke from a pot with embers, jabbed their hands with a nail or used a needle affixed in a mask, etc. (Balys 1993: 50-56). It is also difficult to explain how older people during the interwar period tolerated the abuse that these girls experienced. Genovaitè Jacénaitè described it as follows:

It is better today not to get mad even if the 'Jews' (costumed processioners Ž.Š.) play a practical joke: unleashing the cattle or letting the piglets loose, breaking a jar, pouring milk into the swill, or pouring water into wooden shoes. Better to laugh off everything and even give the pranksters a treat. It could be even worse. I have heard of even greater losses: someone entering a kitchen and tossing a dead crow or rat into the soup, immersing a dungy hobble or wooden shoe into the cream, pushing the housewife into a basket full of eggs, throwing the bucket, sometimes full of milk, into the well... (Jacènaitè 1992: 11) 
To summarise, it is possible to state that during 1920-1940, Užgavènès was already perceived by young people as recreation and relaxation before Lent. In the Lenten period the activities of the youth community were the least intensive of the year in western Lithuania.

\section{URBAN UŽGAVĖNĖS IN THE FIRST HALF OF THE 20TH CENTURY}

A question arises as to how Užgavènès was celebrated in the large cities where the festival had little connection with the agricultural calendar. According to L. Jucevičius, the costumed processions of Užgavènès in the early 19th century were similar to urban masked balls (Jucevičius 1959: 448). As mentioned by Lina Petrošienè, by the 20th century there were already two different, yet interacting traditions: the local-type celebration in rural areas and the imported European-type celebration in noble estates and among city-dwellers (Petrošienè 2013: 14-21). Nevertheless, the urban ritual year was not dissociated from the religious calendar. According to Laima Laučkaitè, the number of celebrations that were connected with the recreational culture born of capitalism, rather than with religion, increased in Vilnius in the early 20th century. The new merriments strictly conformed to the traditional Christian calendar, which in Vilnius dictated a specific recreational rhythm. Public recreation and merriment could not occur during the Orthodox Lenten period (Vilnius at that time being part of the Russian Empire) (Laučkaitè 2008: 472-473). Also there are data that in Vilnius, in the late 19th to early 20th century, women dressed as men and men as women, and visited the homes of the people they knew. Like in villages, people used to eat 6, 7, 9, or 12 times, and pancakes, doughnuts, dumplings, angel wings (sweet crisp pastry), and large quantities of meat were prepared (Znamierowska-Prüfferowa 2009: 162).

But the Užgavėnès of the students in the temporary capital of Lithuania ${ }^{11}$ stands out. A good example of it was the festivity organised by the Student Riflemen's Union in 1936. A gigantic straw effigy of Morè was carted around. In addition to the traditional characters, there were clowns and the straw figure's guard, Kiaulinskis (Pig) ${ }^{12}$. At the Pienocentras (milk processing company) building the clowns 'milked a goat' and 'treated' the nearby people to warm milk (Budreckas 1936: 4). Although the press called the festival participants clowns, this Užgavènès was the first step in holding a Lithuanian Užgavènès in the city. Later on the festival gradually began to spread in the smaller cities of Samogitia (Kudirka 1992: 4). The former agricultural festival was reconstructed in the city and acquired new features. 


\section{THE CONSTRUCTION OF A SOVIET FESTIVAL}

The first post-revolutionary years in Russia showed that elements of traditional calendar festivals could be successfully used for ideological purposes. An important ritual element of the festival was a costumed procession, which is superbly illustrated by the case of Izhevsk (Udmurt Republic, Russia) presented by Maxim Blinov. The main roles in the 1923 carnival were performed by people wearing masks portraying Orthodox, Catholic, Muslim, and Jewish clergymen, and straw figures representing these religions were also carried. After stopping near an Orthodox church, a person in an Orthodox priest's costume began to conduct a mass. Near the executive committee building, a Komsomol member read an announcement, proving the 'pagan' origin of the Christmas festival. Upon completion, the religious straw figures were burnt to the accompaniment of the Internationale (Blinov 2013: 133-134).

Lithuania was under the Communist regime in 1940-1941 and then again in 1944-1990. The first years of the Soviet rule featured mass deportations and a partisan war, and it was not a favourable time to celebrate. On the other hand, the local party figures monitored even innocent attempts to continue former traditions. Užgavènès was regarded as a religious festival and therefore opposed (Kudirka 1992: 4). For example, in western Lithuania, around 1950, those who cooked and ate pancakes during this festival received lower marks for behaviour at school. Young people were also forced to have their hair cut short and go to dances every Saturday throughout the entire Lenten period (Mickevičius 2008: 399). This way the authorities fought against the Catholic traditions forbidding merriment during the Lenten season. Besides denying and banning the old religious festivals during the first years of the Soviet occupation, an attempt was made to create socialist festivals with nothing in common with the traditional ones. As this idea failed, the authorities decided to take advantage of the old festivals by giving them a 'socialist content'. Merriment was encouraged during the Lenten period in another manner, i.e., by holding a winter festival, which replaced Užgavėnès.

In about 1957-1958, Užgavènès began to be revived. It was decided to celebrate the festival in early March (during Lent); mask sketches were ordered, and a famous composer wrote a song for this purpose (Kudirka 1992: 4). A methodical publication Užgavenès - žiemos šventè (Shrove Tuesday - Winter Festival) was published in 1959. It presented recommendations, based on the Samogitian Užgavènès example of how it was possible to adapt this festival to the new traditions of Soviet life (Užgavènès 1959: 1-11). In 1961, regional differences were also examined in the new Užgavènès festival described in the 
methodical publication Naujo gyvenimo tradicijos (New Traditions of Life). A traditional three-meter-high effigy of Morè with a broom and a whip appeared during the winter festival in the vicinity of Pakruojis (north Lithuania). The main goal of the costumed procession was fight against the evil. The traditional symbol of mesédas, the obese Lašininis, was accompanied by bribe takers, profiteers, bureaucrats, bootleggers, and kid-gloved ladies. Meanwhile the escort of Kanapinis, the embodiment of the Lenten period, was formed by traditional characters: a bear, a crane, and clowns. The carnival participants collected carelessly placed objects and the owners had to redeem them with pancakes. After that Lašininis was tried. During visits to various establishments, good workers were praised and slackers rebuked (Černeckis 1961: 9). Morè (the symbol of not only the end of winter, but also of the extermination of all kinds of maladies, evils, and deficiencies) was also burnt in the city of Klaipèda (western Lithuania). But the traditionally lean Kanapinis of the city inhabitants was now pudgy. An ideological explanation was even given: previously, during the fast, Kanapinis had dried out greatly and slimmed down since he had always been very pious and strictly obeyed the church's instructions. Now he had changed completely. Kanapinis no longer believed in religious superstitions and did not keep the fast. On the contrary, he had become an active fighter against everything that was old and obsolete. This positive character sternly criticised the city's evils, and a big tub with idlers, bootleggers, profiteers, and bureaucrats was hitched to the car carrying Kanapinis (ibid.: 8-9). In explaining the festival's origin, the initiator of this Užgavènès festival identified it with the pre-Christian celebration of the spring equinox, which had been moved to Užgavènès after the introduction of Christianity (ibid.: 10).

Although according to Stasys Skrodenis, 1958 was the last year of a real Užgavènès (Skrodenis 2010: 36), in places in Samogitia the traditional Užgavènès still exists (cf. Andriuškevičius 1969: 224-227; Olechnovičienè 2008: 121).

The Winter's Farewell Festival (Lith. Žiemos palydu šventè) more similar to the traditional festival attracted people. In 1977, the Open Air Museum of Lithuania in Rumšiškès began to promote this event. In 1980, the unchanging festival date was set on the last Saturday in February (in fact, even in this case the festival was usually celebrated during Lent). The festival attracted tens of thousands of spectators and tens of folklore ensembles. Although the festival in Rumšiškès levelled the festival's regional differences, according to ethnologist Juozas Kudirka, the festival encouraged people to take an interest in customs as something valuable (Kudirka 1992: 4). Užgavènès, renamed 'Winter's Farewell', the authentic masks, and the cry 'Winter, winter, flee our courtyard!' chanted by thousands of people has gradually given it the features of a 'pre-Christian' 
winter-end ritual, granting it the value of a festival marking the change of seasons. This has caused the festival's success and its rapid spread in Lithuania.

In 1959, the Spring Festival, which was to replace Easter, with the main role played by Old Man Cold, who symbolised the winter period and handed the keys over to Young Man Spring, began to be celebrated (Vyšniauskaitė 1964: 554-556). But this festival did not embody the symbols of the changing of the seasons and did not become established; nor did the Harvest Festival carnival organised in September-October (ibid.: 556-558). These newly created festivals disappeared whereas Užgavènès survived. A festival that evokes no connection with any tradition, as has been mentioned by Catherine Bell, is apt to be found anomalous, inauthentic or unsatisfying by most people (Bell 1997: 45).

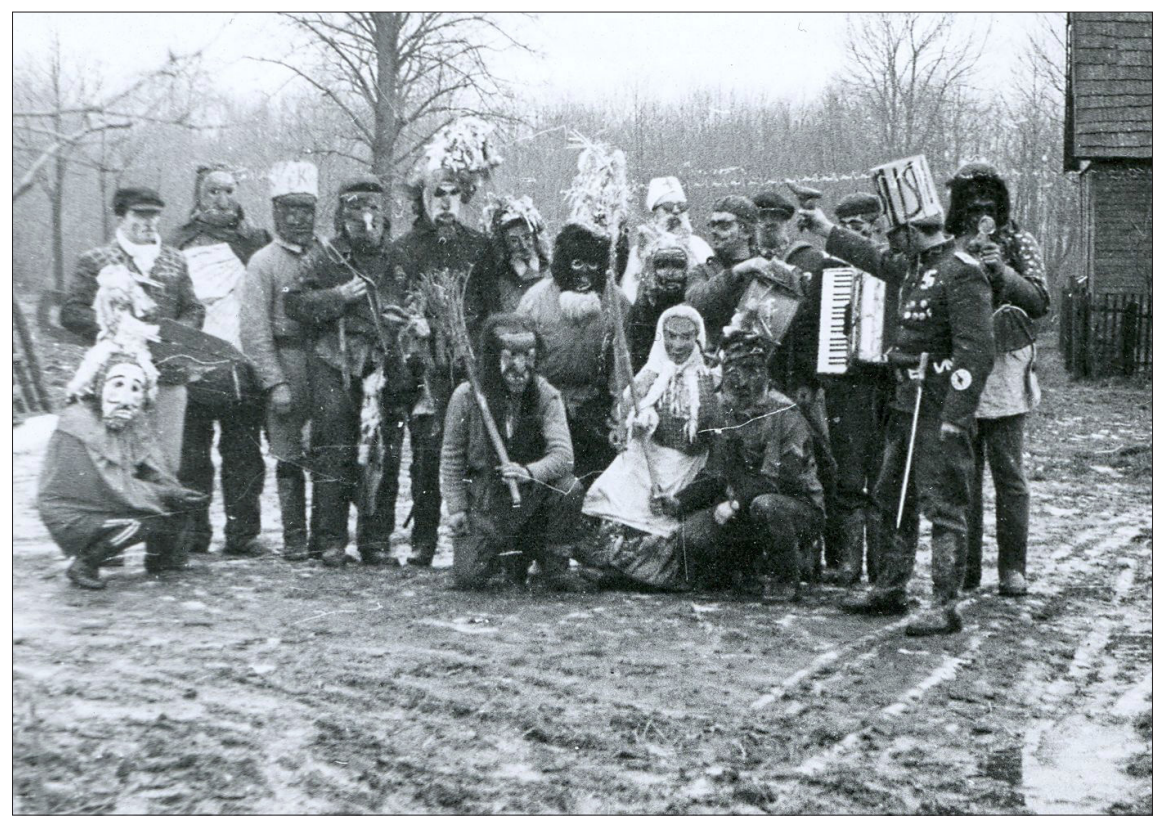

Figure 3. Užgavènès. Plateliai, Plungè district. Photograph by Juozas Mickevičius 1973. MFL, photographic negative No. 80111. 


\section{UŽGAVĖNĖS IN THE 21ST-CENTURY LITHUANIA}

During the years 1988-1990, attention greatly focused on the rejuvenation of pre-Soviet calendar festivals. Rarely did a newspaper or journal, radio station or television channel not recall the 'traditional' Užgavènès customs in an article or programme. This rejuvenation process was actively encouraged. In 1992, books devoted to this festival were published by ethnologists Juozas Kudirka and Inga Krikščiūnienè. A methodical publication in 1996 instructed readers on how to revitalise the festival using ethnographic and folklore material from local people, compiled on site, and to awaken the memory of older people during the festival (Kudirka 1996). However, this practice is not justified in the case of Užgavenès. In many Lithuanian localities this festival is based on slightly adjusted Užgavėnès programmes created during the Soviet era. As is shown by fieldwork in 150 Lithuanian villages and towns, in the 21st century Užgavènès costume customs predominate (masked processions on other traditional occasions - for example, Epiphany - are rare and only isolated instances of other traditional costumed groups have been recorded). Similar to the Soviet era, the festival is frequently celebrated on the weekend, but without moving it into the Lenten period, and the costumed figures devised during the Soviet era are rejected. The Soviet festival was widespread throughout Lithuania. Yet, field research revealed different assessments of the Užgavènès festival in the Lithuanian countryside and cities. Some people think that a real festival should be held on a day off; some (e.g. schoolchildren) think that it is an important festival. Festival mood predominates during classes at schools, and some of them, especially at primary school, are conducted only formally. The opportunity to participate in a costumed procession, an evening dance or a party organised in a group of friends, and/or the town's festival events, live music, and an Užgavènès bonfire make an ordinary school day seem like a holiday. As is seen in Figure 4, almost everywhere in Lithuania events are organised on the occasion of Užgavènès and bonfires are lit to drive out winter (Šaknys 2007: 86).

Young people in south Lithuania organise mainly recreational evenings (Šaknys 2012: 101). Costumed processions of young people (aged 14 and older) are also popular in this part of Lithuania. In other ethnographic regions, only groups of younger children usually parade in costumes (Šaknys 2007: 86; 2009: 80; 2012: 102).

Field research shows that costumed processions participated by girls only or jointly by girls and boys currently prevail. A somewhat different situation exists only in Samogitia, where in some places the processions take place on two days, the first one being called the beggars' day and the second one the Jews' day. On the first day, only children parade in costumes, on the second day young people 


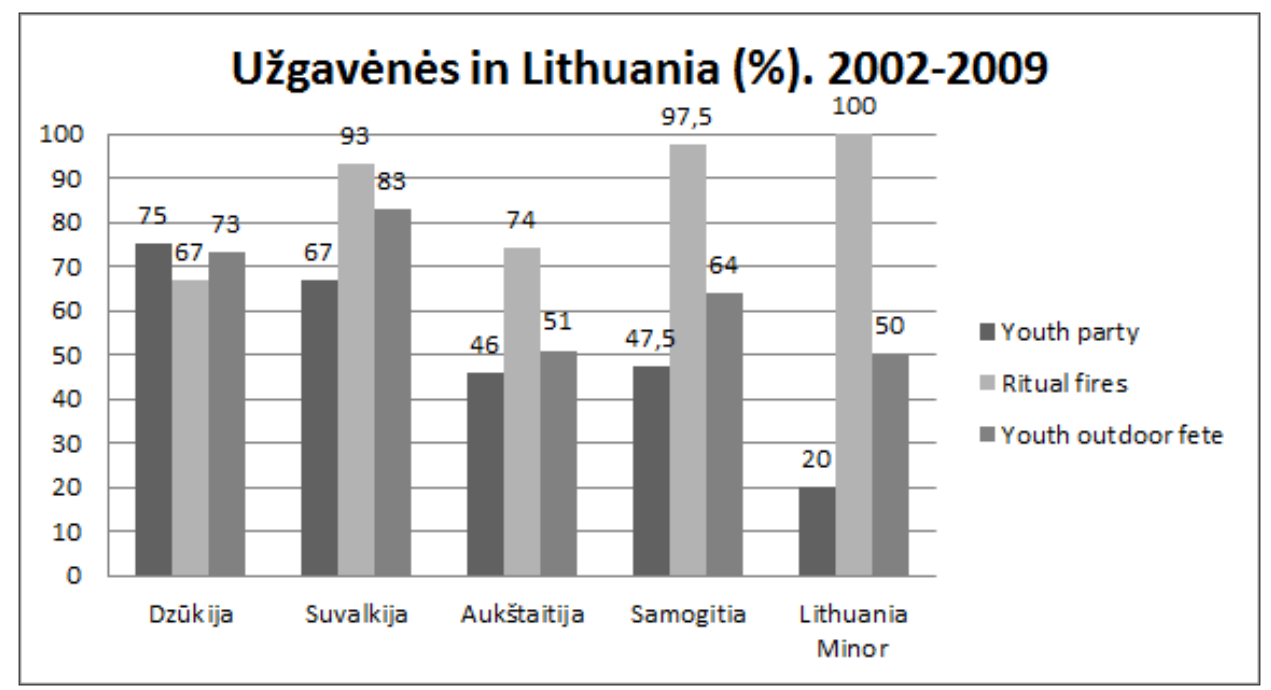

Figure 4. Youth activity at Užgavenès in different parts of Lithuania (2002-2009) (data from Šaknys 2007: 86; Šaknys 2009: 80; Šaknys 2012: 101-102).

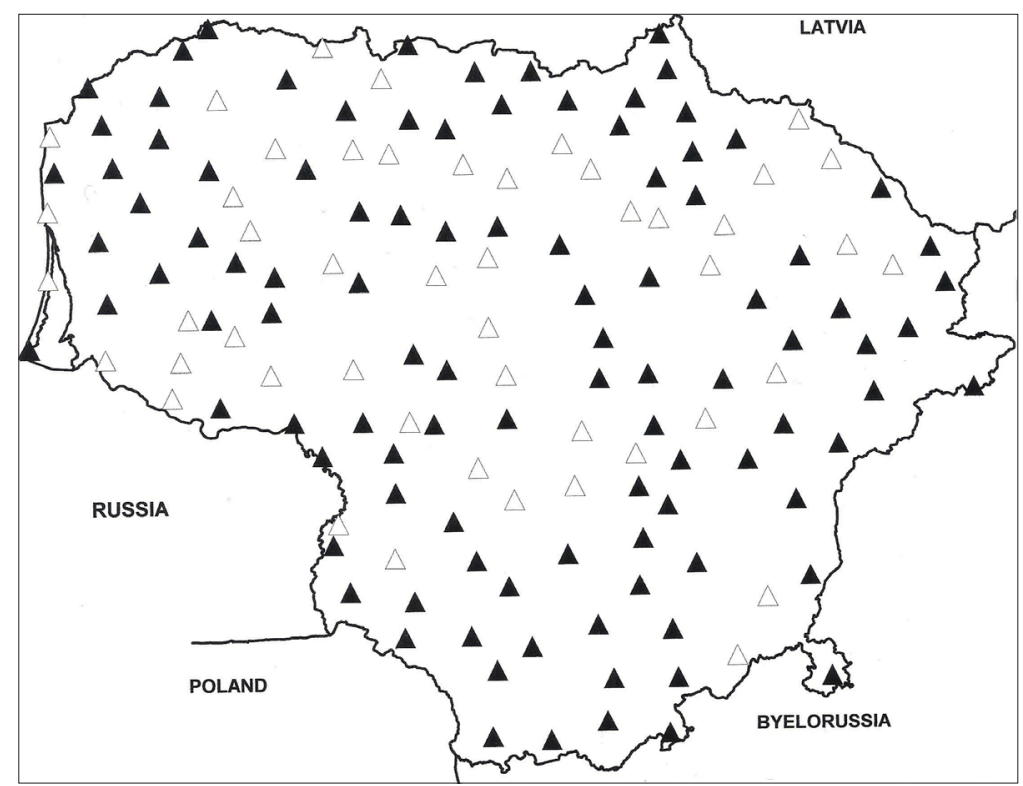

Figure 5. $\Delta$ Youth and children's outdoor fetes at Užgavènè; $\triangle$ Children's outdoor fetes at Užgavenès (2002-2009) (data from: Šaknys 2007: 107; Šaknys 2009: 99; Šaknys 2012: 125). 
and adults. In Grūšlaukè, for example, on the first day 6-13-year-old 'little beggars' and on the second day 15-24-year-old 'Jews' parade. Somewhat differently than in the majority of the localities in Lithuania, the boys are more active in this area (Šaknys 2012: 93). A similar situation can also be seen in Vilnius, where the costumed processions have acquired a commercial character. For example, according to one respondent, they used to dress up as Jews, Gypsies, and devils at Užgavènès. In groups of six they visited bars and cafes, promising 'to drive out winter' in exchange for gifts. They used to be rewarded with sweets and money. When comparing young people's costume customs in the provinces and in the capital, we can say that they are more diverse in Vilnius, where they are not concentrated on only Užgavènès, but also encompass other traditions and modern festivals. According to as much as a third of Vilnius residents, carnivals are also organised on Halloween. Many Vilnius residents are also attracted to the Epiphany festival organised by the Vilnius Ethnic Culture Centre, and they go to fancy dress or theme parties during Christmas and New Year and even on St. Valentine's Day (Šaknys 2013: 103-106). According to A. Vaicekauskas, Lithuania is distinguished from the rest of the Baltic region by its surviving traditional style costumed figures. In fact, modern Western popular culture tendencies can also be encountered (Vaicekauskas 2013: 48-56). Užgavènès is spreading beyond Lithuanian borders, but is being called a Lithuanian festival rather than a boundary festival marking the change in seasons or the driving out of winter.

\section{THE SPREAD OF UŽGAVĖNĖS BEYOND LITHUANIAN BORDERS}

The analysis of the situation in the late 19th and early 20th centuries reveals that Užgavenès costume parade customs were also known in the neighbouring lands: in the present-day territories of Latvia (Olupe 1992: 87-92), Belarus (Kukharonak 2001: 78-80) and Poland (Drożdż 2002: 285-289). However, Užgavenès costume customs were not known in the areas of these countries that bordered on present-day Lithuania. This allowed the Lithuanians of these states who were living in the border areas to perceive these Užgavenès customs as 'Lithuanian', and the local non-Lithuanian inhabitants to recognise their Lithuanian nature.

The largest Lithuanian community close to Lithuanian border is in the vicinity of Punskas (Puńsk) in northeast Poland. According to the recollections of Aldona Vaicekauskienè, in 1981, the ethnographic club of Puńsk School and 
the Lithuanian Society culture club of Puńsk Lyceum organised an Užgavènès festival with a costumed procession, riding in sledges, a bonfire, traditional food, and dancing (Vaicekauskienè 1996a: 177-182). Thus another 'Lithuanian' symbol, i.e., dressing up in costumes, was added to this region's traditional Užgavènès customs of dancing and sledge-riding. In 1985 an attempt was made through the ethnographic club to recreate a theatricalised Užgavènès festival. The pupils were encouraged to appear at the Węgorzewo Spring Festival, where calendar customs from different areas of Poland were presented. They modelled the performance of Samogitian traditions ${ }^{13}$, which they had become acquainted with in Lithuania. According to A. Vaicekauskienè, young people keen on ethnography had come from Lithuania through the club's efforts and had taught the local population new folk dances and games. One of the club members had also had an opportunity to become acquainted with Lithuanian folklore in Lithuania. After returning home she taught the local young people in Puńsk Lithuanian songs, dances, and games (Vaicekauskienè 1996b: 158). Thus the Soviet era Užgavènès became a festival of the Lithuanian diaspora in Poland.

The custom of masking on Užgavènès could not have been so easily established in the Lithuanian community in southeast Latvia since costumed Christmastide processions occurred in this part of Latvia and in the northeast of Lithuania bordering it, but in the late 20th century Lithuanian Užgavènès costume customs started to take root in this region (Šaknys 2001b: 236, 241). Later on this custom migrated to the Lithuanian villages in the vicinity of Gervèčiai (Gervyaty) village in western Belarus. Fairly archaic customs have survived in the villages that have not separated into isolated farmsteads. Yet, Lithuanian Užgavènès began to spread there as well (2011 and 2012 field research data).

The Užgavėnès programmes are somewhat different in the Lithuanian communities in the countries that do not border on Lithuania. However, they are united by a common feature. Užgavènès is becoming 'Lithuanian' only in a polyethnic environment where no festival of a similar nature is celebrated. As Jeremy Boissevain has noted:

One of the most traditional and effective ways to stress the identity of a group is to celebrate a fète or ritual together. In doing so, one can feel 'at home' among each other. One creates a 'face' vis-à-vis other groups. The celebration of festivals is not only a reflection of one's own identity; it is at the same time the model for the manifestation of an identity. (cited in Van Ginkel 2007: 37) 
The internet sources and interviews show that the festivals are organised by the embassy staff, members of the Lithuanian community, foreign Lithuanian youth organisations, the teachers at Lithuanian language Saturday schools, or simply groups of friends. In some cases exceptional significance is attached to Užgavènès. For example, the Lithuanian organisation in Tallinn, Estonia (Šimkute 2012), the Lithuanian organisation Židinys (Hearth) in Moscow, and the Lithuanian Šaltinèlis (Wellspring) Gymnasium in Moscow celebrate only three festivals: Christmas, Easter, and Užgavėnès (Rusijos Lietuviu Bendruomenių Sajunga). Saule Lithuanian language school in Stockholm celebrates Lithuanian Independence Day (February 16), Christmas, Užgavėnės, and Easter (Lietuvių Bendruomenè Švedijoje).

Užgavėnès is already being organised by using modern means. For example, the Lithuanian Youth Union SILTA in Finland organised the festival in Helsinki. Especially for this occasion, the organisers created a Facebook page titled 'Užgavènès', where they invited people to come to Alppipuisto Park in Helsinki on February 10, 2013. Young people decorated a tree with the colours of the Lithuanian flag (as they did not have a big flag). About 20 people assembled. Lithuanians living in Finland came not only with their children, but also with their non-Lithuanian spouses. The participants brought pancakes, cakes, crackers, homemade jam, tea, and coffee. Some also brought Užgavėnès masks they had made. A competition between Kanapinis and Lašininis teams was planned at the festival. Children rode on sleds and other sliding devices. There were snow carrying and tug-of-war competitions and later a mini-Morè was burnt. One of the festival participants described the Užgavènès celebration during an interview. When asked why Užgavènès had been selected, the interviewee answered:

We selected Užgavenès because it is a very pleasant and interesting Lithuanian [emphasis mine - Ž.Š.] festival during a fairly dreary time of the year. It was also an excellent occasion for everyone to meet and do something together. Do we miss our homeland? Perhaps. Although we do not live far from Lithuania and visit our homeland fairly frequently, we miss the language as well as 'our faces', food, and humour. Both the SILTA youth union and the Lithuanian community in Finland actively organise various meetings and events, through which they encourage the preservation of their Lithuanian traditions and promote interaction among Lithuanians. We are all 'strangers' here and do not have the kind of strong ties we would have in Lithuania. (e-mail interview on December 2-3, 2013) 


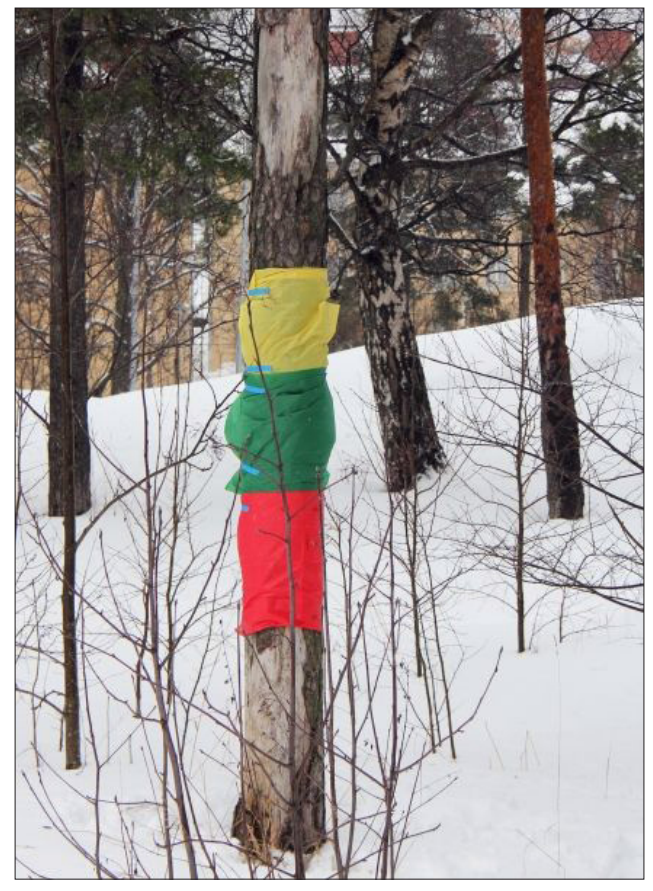

Figure 6a. Tree decorated with the colours of the Lithuanian flag.

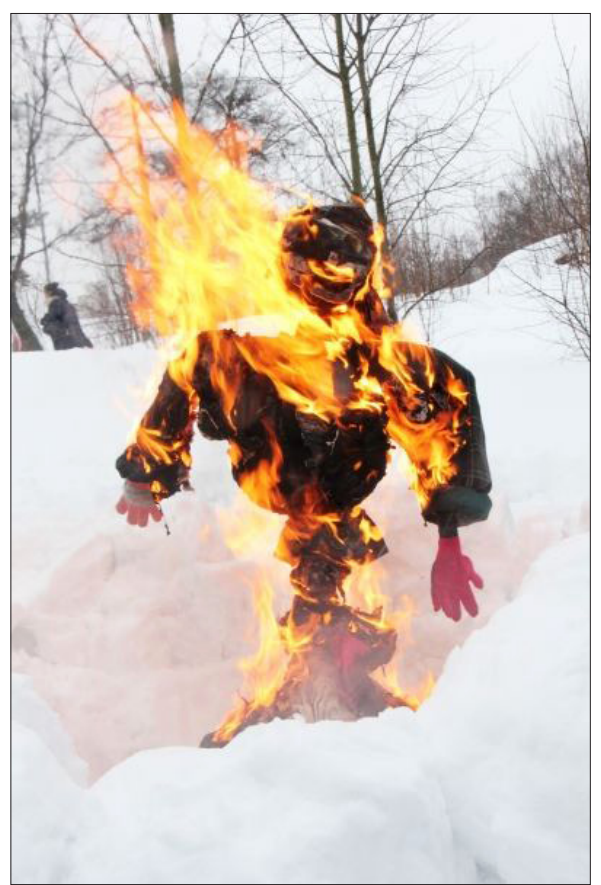

Figure 6b. Burning a mini-Moré. Finland.

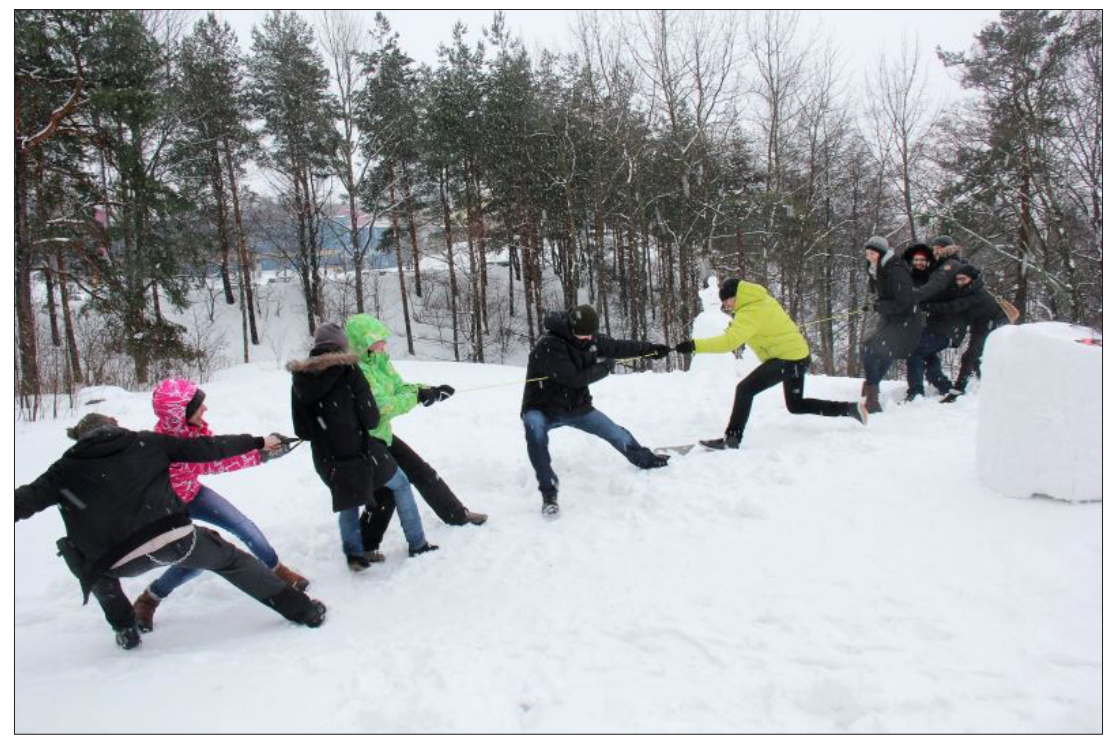

Figure 6c. Competition between Kanapinis and Lašininis teams. Photographs by Rūta Gjerde 2013. 
But there is no winter to be escorted or driven out in every foreign country. In some countries, like, for example, Greece, Užgavėnès is marked only by a general assembly of Lithuanians and the eating of pancakes (e-mail and telephone interviews on March 3, 2013, and December 3, 2013). Traditional foods can be a way for earning money. For example, a woman who immigrated from Lithuania Minor to Canada around 1950, popularised the tradition of eating stew on Pancake Tuesday among her fellow countrymen, using the money she had collected from the participants to support national organisations (Blockytè 2010: 258-259).

The central festival symbols include masked people, Moré, Kanapinis and Lašininis, and traditional Lithuanian dishes. It often takes only one traditional festival symbol to create, in the words of Jolanta Kuznecoviene, a deterritorialised ethnic cultural space (Kuznecovienè 2011: 93) that allows people to be safe and 'feel at home'.

\section{CONCLUSIONS}

The conducted research shows the transformations of the content of the Užgavenès festival over the course of time. The research reveals that the agrarian festival also had the features of a religious festival. The real effect of Christianity was not direct, but was connected with the structure of the Catholic ritual year. Užgavènès was the last day before the 46-day Lenten fast, which affected the festival mood and folk customs and provided a pretext during the Soviet occupation to call Užgavènès a religious festival.

Through the performance of many of the agricultural rituals by the youth and children, the festival acquired a recreational meaning. It also had such a meaning in the city where a pan-European recreational culture lacking any national character had formed. In the fourth decade of the 20th century Užgavènès acquired a national character. The Lithuanian festival, which began to spread also in the smaller cities, was created in Kaunas, the temporary capital of Lithuania, on the basis of Užgavènès traditions that existed in westLithuanian villages. This experience was also used in creating the socialist Užgavènès festival in Soviet Lithuania.

After the authorities had failed to create successful socialist festivals that had nothing in common with the traditions, it was decided to use the old festivals by giving them a 'socialist content'. The main accent of the Užgavėnès festival was shifted to the costumed procession. The costumed characters portrayed positive and negative figures that had to show the advantages of the new socialist life, 
fight against religion, praise good workers, and rebuke slackers. On the other hand, Užgavėnès, which maintained closer ties with the tradition, acquired the features of a ritual for driving out winter, and giving it the value of a festival marking a change in the seasons.

While discussing the creation of a Soviet ritual year in Lithuania and the meaning of the Užgavènès festival in this structure, several frequently intertwining meanings can be detected: the fight against religiousness, the objective of creating a socialist festival, the efforts to nurture Lithuanian festivals, and the encouraging of young people to take an interest in the ancient pre-Christian customs. This festival, which is treated in various ways, corresponded to the expectations of the gradually secularising general public throughout Soviet Lithuania.

Up until now, the status of Užgavènès as a festival for driving out winter and marking a change in the seasons has determined its fate and has even rendered meaning to it. Its spread in Lithuanian communities abroad has created a temporary deterritorialised Lithuanian ethnic cultural space and allowed people to feel 'at home' among their own kind and to maintain their ethnic identity.

\section{NOTES}

1 Shrove Tuesday is the traditional day of celebrating. However, many Lithuanians who are busy on this day, or due to other reasons, celebrate it on another - nonworking - day, which is close to this particular Tuesday. In the article, I have used the Lithuanian name Užgavenès to denote this festival.

${ }^{2}$ Lithuania consists of five ethnographic regions: Lithuania Minor and Samogitia in the west, Suvalkija in the southwest, Dzūkija in the southeast; Aukštaitija, the largest ethnographic region, covers the rest of the country.

3 The costumed figures embody representatives of ethnic groups, who in the agricultural community symbolised 'other' people who were engaged in non-agricultural professions (Anglickienè 2011: 10).

4 The Hungarians were known as physicians; in the processions they offer to check people's health and to sell them medicines.

5 The Jews were known as merchants; in the processions they offer to sell things to people.

6 A traditional Užgavènès costume portraying a very obese man who personifies satiety and symbolises the period from Christmas to Shrove Tuesday (Lith. mésedas).

7 A traditional Užgavėnès costume portraying a very thin man who personifies fasting and symbolises the period from Ash Wednesday to Easter. Kanapinis playfully battles Lašininis during the procession, eventually defeating him. 
8 A female figure, which is sometimes drowned or burnt during traditional Samogitian Užgavènès festivals.

9 In Lithuania, until the second half of the 20th century, it was not traditional to bake and eat pancakes on Shrove Tuesday.

${ }^{10}$ For example, 16,871 tickets were sold in $2011,16,343$ in $2012,16,477$ in 2013 , and 15,186 in 2014 (museum information as of 27.10.2014).

${ }^{11}$ During 1920-1939, Vilnius belonged to Poland and the capital of the Republic of Lithuania was moved to Kaunas.

${ }^{12}$ An analogy to the traditional Užgavènès character of Lašininis.

${ }^{13}$ Puńsk borders only on Dzūkija and Suvalkija ethnographic regions.

\section{ARCHIVAL SOURCES}

MFL - Manuscript fund of the Lithuanian Institute of History. Files 1272, 1318, 1319, $1325,1330,1334,1379-1388,1422,1442,1446-1452,1457,1505,1534-1536,1661$ 1664, 1693-1695, 1998-2000, 2075, 2219, 2309, 2328, 2334, 2340, 2341 (Žilvytis Šaknys' fieldwork materials from 1988 to 2009).

MFL, file 949. Mickevičius, Juozas. Užgavènès [Shrove Tuesday] (photographs in the file). MFL, photo negative No. 80111.

\section{MANUSCRIPT SOURCES}

Fieldwork materials from the years 2012 to 2013 in possession of the author.

\section{REFERENCES}

Andriuškevičius, Alfonsas 1969. Užgavėnès Grūšlaukyje. [Shrove Tuesday in Grūšlaukis.] Kraštotyra, pp. 224-227.

Anglickienè, Laima 2011. Kitataučių personažų transformacijos persirengimo papročiuose. [Transformations of Strangers' Masks in Lithuanian Feasts.] Tradicija ir dabartis, Vol. 6, pp. 9-24.

Balys, Jonas 1993. Lietuviu kalendorinès šventès. [Lithuanian Calendar Customs.] Vilnius: Mintis.

Bell, Catherine 1997. Ritual: Perspectives and Dimensions. New York \& Oxford: Oxford University Press.

Blinov 2013 = Blinov, Maksim. Grazhdanskaia kul'tura provintsial'nogo goroda v rannesovetskii period (na primere Izhevska). [Civil Culture of a Provincial Town in the Early Soviet Period (Izhevsk Case).] In: J. Mardosa (ed.) Šventès moderniame mieste / Festivals in the Modern City. Vilnius: Edukologija, pp. 127-137. 
Blockytè, Kristina 2010. Užgavènių šventès (Šiupinio vakaro) specifika Klaipėdos krašte. [The Specifics of the Shrove-Tide Celebrations (Stew Eve) in the Klaipeda Region.] Res Humanitariae VII, pp. 243-265. Available at http://www.ku.lt/leidykla/ files/2012/09/Visas_tekstas_2010_17.pdf, last accessed on February 3, 2015.

Budreckas, Petras 1936. Žemaitiški Užgaveniu papročiai Laisvès Alejjoje. [Samogitian Shrove Tuesday Customs in Laisvės Boulevard.] Newspaper Lietuvos aidas, No. 96, p. 4. Available at http://www.epaveldas.lt/vbspi/biRecord.do?biExemplarId=67120, last accessed on February 4, 2015.

Černeckis, Vincas 1961. Naujo gyvenimo tradicijos. [Traditions of a New Life.] Vilnius: Valstybinè politinès ir mokslinès literatūros leidykla.

Drożdż, Anna 2002. Komentarze do Polskiego Atlasu Etnograficznego. T. VII. Pomoc wzajemna: Wspótdziatanie społeczne $i$ pomoc sasiedzka. [Commentaries to the Polish Ethnographic Atlas. Vol. VII. Mutual Help: Social Cooperation and Neighbours' Help.] Wrocław \& Cieszyn: Polskie Towarzystwo Ludoznawcze \& Uniwersytet Śląski Filia w Cieszynie.

Jacėnaitè, Genovaitè 1992. Užgavėnės Užventyje. [Shrove Tuesday in Užventis.] Liaudies kultūra, No. 1, p. 11.

Jucevičius, Liudvikas Adomas 1959. Raštai. [Writings.] Vilnius: Valstybinė grožinès literatūros leidykla.

Krikščiūnienè, Inga 1992. Užgavėnès. [Shrove Tuesday.] Vilnius: Techlab.

Kudirka, Juozas 1992. Užgavenès. [Shrove Tuesday.] Vilnius: Mokslas.

Kudirka, Juozas 1996. Papročiai ir kaimo kultūra. [Customs and Folk Culture.] Vilnius: Lietuvos Respublikos žemès ūkio rūmai.

Kukharonak 2001 = Kukharonak, Tatstsiana. Maski v kalendarnoi obriadnosti Belorussii. [Masks in Calendar Rituals of Belarus.] Minsk: Uradzhai.

Kuznecovienè, Jolanta 2011. Išteritorinto identiteto alternatyvos: Lietuvių emigrantai Airijoje, Anglijoje, Ispanijoje ir Norvegijoje. [Deterritorialised Identity Alternatives: Lithuanian Emigrants in Ireland, UK, Spain, and Norway.] In: Vytis Čiubrinskas (comp.) Lietuviškas identitetas šiuolaikines emigracijos kontekstuose. [Lithuanian Identity in the Context of Modern-Day Emigration.] Kaunas: Vytauto Didžiojo universitetas, pp. 89-104.

Laučkaitè, Laima 2008. Vilniaus šventès ir pramogos prieš Pirmajį Pasaulinį karą. [Vilnius Festivals and Recreation before the First World War.] Naujasis židinysAidai, No. 11-12, pp. 468-475. Available at http://www.nzidinys.lt/files/various/ NZ-A\%202008\%20nr\%2011\%2012.pdf, last accessed on February 4, 2015.

Merkienė, Irena Regina 2011. Kalendorinių švenčių apeigos. [Rituals in Calendar Festivals.] In: Vida Savoniakaitè (ed.) Lietuvos etnologijos ir antropologijos enciklopedija. [An Encyclopaedia of Lithuanian Ethnology and Anthropology.] Vilnius: LII leidykla, pp. 173-174.

Mickevičius, Juozas 2008. Tévu ir proteviu žemé: I knyga. [The Land of Parents and Grandparents: 1st Book.] Vilnius: Regionų kultūrinių iniciatyvų centras.

Olechnovičienè, Vida 2008. Lietuvos liaudies buities muziejus: Kalendorinių švenčių papročiai. Tradicijos atgaja. [Open Air Museum of Lithuania: Customs of Calendar Festivals. Refreshing of the Tradition.] Gimtasai kraštas, Vol. 1, pp. 120-126. Available at http://www.ziemgala.lt/lt/metrastis-gimtasai-krastas/gimtasaikrastas-2008/lietuvos-liaudies-buities-muziejus-kalendoriniu-svenciu-paprociaitradicijos-atgaja, last accessed on February 4, 2015. 
Olupe, Edīte 1992. Latviešu gadskārtu ieražas. [Latvian Calendar Customs.] Rīga: Avots. Petrošienè, Lina 2013. Užgavėnių šventès atgarsiai lietuviškoje XX a. pirmosios pusès periodikoje: kaip šventè miestiečiai? [Glimpses of the Shrovetide Holiday in the Early 20th Century Lithuanian Press: How Townspeople Celebrated It.] Istorija, Vol. 2 (90), pp. 14-21. Available at http://www.istorijoszurnalas.lt/images/stories/ Istorija_90/Istorija90.pdf, last accessed on February 4, 2015.

Šaknys, Žilvytis 1996. Jaunimo brandos apeigos Lietuvoje: XIX a. pabaigoje - XX a. pirmojoje puseje. [Youth's Initiation Rites in Lithuania: End of the 19th - 1st Half of the 20th Centuries.] Vilnius: Pradai.

Šaknys, Žilvytis 2001a. Kalendoriniai ir darbo papročiai Lietuvoje XIX a. pabaigoje $\mathrm{XX}$ a. pirmoje pusejje: Jaunimo vakarèliai. [Lithuanian Calendar and Work Customs in the Late 19th - 1st Half of the 20th Centuries: Youth Parties.] Vilnius: Diemedžio leidykla.

Šaknys, Žilvytis 2001b. Pietryčių Latvijos lietuviai: kultūra, etniškumas ir bendraamžiu bendrija. [Lithuanians in Southeast Latvia: Culture, Ethnicity and the Community of Peers.] Lietuvos etnologija: Socialinès antropologijos ir etnologijos studijos, Vol. 1 (10), pp. 231-250. Available at http://etalpykla.lituanistikadb.lt/fedora/ objects/LT-LDB-0001:J.04 2001 1367158523539/datastreams/DS.002.0.01. ARTIC/content, last accessed on February 4, 2015.

Šaknys, Žilvytis 2007. Jaunimo iniciaciniai ir kalendoriniai papročiai. [Youth Initiation and Calendar Customs.] In: R. Paukštytė-Šaknienė \& V. Savoniakaitė \& Ž. Šaknys \& I. Šidiškienè (eds.) Lietuvos kultūra. Aukštaitijos papročiai. [Lithuanian Culture: Traditions of Aukštaitija.] Vilnius: LII leidykla, pp. 65-116.

Šaknys, Žilvytis 2009. Jaunimo iniciaciniai ir kalendoriniai papročiai. [Youth Initiation and Calendar Customs.] In: R. Paukštytè-Šaknienè \& V. Savoniakaitè \& Ž. Šaknys \& I. Šidiškienè (eds.) Lietuvos kultūra:Dzūkijos ir Suvalkijos papročiai. [Lithuanian Culture: Traditions of Dzūkija and Suvalkija.] Vilnius: LII leidykla, pp. 64-110.

Šaknys, Žilvytis 2012. Jaunimo iniciaciniai ir kalendoriniai papročiai. [Youth Initiation and Calendar Customs.] In: R. Paukštytė-Šaknienè \& V. Savoniakaitè \& Ž. Šaknys \& I. Šidiškienè (eds.) Lietuvos kultūra: Mažosios Lietuvos ir Žemaitijos papročiai. [Lithuanian Culture: Traditions of Lithuania Minor and Samogitia.] Vilnius: LII leidykla, pp. 77-135.

Šaknys, Žilvytis 2013. Ritualiniai metai šiuolaikinèje Lietuvoje: Miesto ir kaimo perspektyvos. [Ritual Year in Contemporary Lithuania: Prospects of City and Province.] In: J. Mardosa (ed.) Šventes moderniame mieste / Festivals in the Modern City. Vilnius: Edukologija, pp. 100-109.

Šimkutè, Dalia 2012. Kazimiera Vellemaa: "Dabar jau mano šaknys ten, Estijoje". [Kazimiera Vellemaa: "Now my roots are there in Estonia".] Newspaper Vakarine Palanga, November 19. Available at http://www.vakarinepalanga.lt/ lt/archyvas/?id=3577, last accessed on February 4, 2015.

Skrodenis, Stasys 2010. Folkloras ir gyvenimas. [Folklore and Life.] Vilnius: Vilniaus pedagoginio universiteto leidykla.

Užgavėnès 1959 = Užgavènès - žiemos šventè. [Shrove Tuesday - Winter Festival.] Metodinè medžiaga. Vilnius: LTSR kultūros ministerija \& Respublikiniai liaudies kūrybos namai. 
Vaicekauskas, Arūnas 2005. Lietuviǔžiemos šventès: Bendruomeninès kalendorinio ciklo apeigos XIX a. pab. - XX a. pr. [Lithuanian Winter Festivals: The Rites of the Community Calendar Cycle in the Late 19th - Early 20th Centuries.] Kaunas: VDU leidykla.

Vaicekauskas, Arūnas 2010. Lietuvių Užgavėnès: Nacionalinio tapatumo linkme? [Lithuanian Shrovetide Customs: Towards National Identity?] Liaudies kultūra, No. 2, pp. 23-29. Available at http://www.llkc.lt/index.php?1532573788, last accessed on February 4, 2015.

Vaicekauskas, Arūnas 2013. Carnival Culture in the Baltic Region: New Tendencies. In: Arūnas Vaicekauskas (ed.) The Power of the Mask: The Ritual Year 5. Kaunas: Vytautas Magnus University, pp. 48-54.

Vaicekauskienè, Aldona 1996a. Iš Punsko licejjaus LVKD būrelio veiklos. [From Puńsk Lyceum LVKD Circle Activities.] In: M. Černelienè (ed.) Punsko Kovo 11-osios lietuviu gimnazija. [Gymnasium of the 11th March in Puńsk.] Punskas: Aušra, pp. $177-182$.

Vaicekauskienè, Aldona 1996b. Gimnazijos etnografinis būrelis. [Gymnasium Ethnographic Club.] In: Punsko Kovo11-osios gimnazija. [Gymnasium of the 11th March in Puńsk.] Punskas: Aušra, pp. 156-162.

Van Ginkel, Rob. 2007. Celebrating Localism: The Festive Articulation of Texel's Identity. In: Peter Jan Margry \& Herman Roodenburg (eds.) Reframing Dutch Culture: Between Otherness and Authenticity. Wiltshire: Ashgate, pp. 37-57.

Vèlius, Norbertas (ed.) 1996. Baltų religijos ir mitologijos šaltiniai. [Sources of Baltic Religion and Mythology.] Vol. 1. Vilnius: Mokslo ir enciklopedijų leidybos institutas.

Vyšniauskaitè, Angelè 1964. Naujų tarybinių papročiu formavimasis. [The Formation of New Soviet Customs.] In:Lietuvių etnografijos bruožai. [Lithuanian Ethnography.] Vilnius: Valstybinè politinès ir mokslinès literatūros leidykla, pp. 551-567.

Znamierowska-Prüfferowa, Maria 2009. Vilnius, Miestas arčiausia širdies. [Vilnius: The City Closest to my Heart.] Vilnius: Alma littera.

\section{INTERNET SOURCES}

Užgavėnès Vilniuje! Renginių programa. [Shrove Tuesday in Vilnius! Event programme.] Available at http://www.makalius.lt/kelioniu-naujienos/uzgavenes-vilniuje-renginiuprograma, last accessed on January 23, 2015.

Prezidentè D. Grybauskaitè: Užgavènès tai - kvietimas kiekvienam įveikti negeroves ir atsinaujinti. [President D. Grybauskaitè: Shrove Tuesday is an invitation to each of us to overcome problems and to renew ourselves.] Available at http://alkas. lt/2013/02/12/prezidente-d-grybauskaite-uzgavenes-tai-kvietimas-kiekvienamiveikti-negeroves-ir-atsinaujinti-video/, last accessed on February 3, 2015.

Rusijos Lietuvių Bendruomenių Sajunga. [Union of Russian Lithuanian Communities.] Available at http://www3.lrs.lt/pls/inter/w5_show?p_r=509\&p_d=7286\&p_k=1, last accessed on February 3, 2015.

Lietuvių Bendruomenè Švedijoje. [Lithuanian Community in Sweden.] Available at http://www.lietuviai.se/index.php?page=saule, last accessed on February 3, 2015. 


\section{IN MEMORIAM}

\section{ÜLO TEDRE}

FEBRUARY 12, 1928 - MARCH 9, 2015

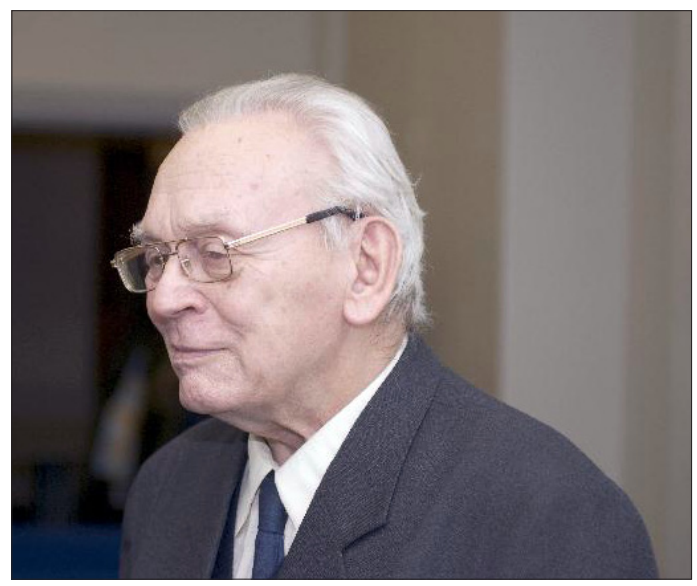

March 9, 2015, was the last day of Ülo Tedre's life and scholarly career. His legacy is comprised of more than 400 written, compiled and edited works, which cover practically all folklore genres as well as Estonian literary and cultural history, such as Eesti mees ja tema sugu (Estonian Man and His Kin) (1952-1954/2003), the four-volume Estonian folk song anthology (1969-1972), a short monograph Eesti pulmad (Estonian Weddings) (1973), a beautiful album to celebrate Jakob Hurt's 150th birth anniversary (1989), the song collections of Jõhvi and Iisaku parishes in the series Vana Kannel (Old Zither) (1999), a voluminous overview of Estonian mumming and masking traditions published in Sweden (2007), to name but a few. In addition, he published a number of shorter writings about the Estonian runo song, beliefs and practices, and about Estonian folklore classics Jakob Hurt, Matthias Johann Eisen, Oskar Loorits, and Walter Anderson, as well as overviews of Estonian folklore in different collections and school textbooks, and more than 70 reviews on folkloristics, literature, and culture. We should also mention his fruitful collaboration with Veljo Tormis in reinstating the original runo song in Estonian choir music, his work as head of the folklore section at the Institute of Estonian Language and Literature (1962-1991), membership of different professional associations and boards, and the III Class Order of the White Star conferred on him in 2000. 
The majority of Ülo Tedre's scholarly works have been enumerated in the bibliography compiled by Karin Maria Rooleid in 2008, and his scholarly contribution has been abundantly cited by folklorists from Estonia, Finland and other countries. Yet, I have found only one writing in which Tedre's works have been analytically analysed.

Considering the extent of Ülo Tedre's research and scholarly activities, it is understandable that the number of people who knew him and with whom he communed was enormous. It is hard to guess, in retrospect, which clusters and strata were involved. Most of his contemporaries have already passed away, and their memories about Ülo Tedre as a person both inside and outside the world of research, with all his rational and emotional characteristics, interests and hobbies, are lost for us; so, in-depth information about Ülo Tedre's life events is rather scarce.

There is a portrait film by Vallo Kepp, titled "Life as a Runic Verse: Ülo Tedre" (1994), in which Tedre himself and several of his colleagues speak about him. Also, the scholar published his reminiscences of life and people at the folklore section of the Institute of Estonian Language and Literature in the years 1947-1990 in a collection Eesti filoloogia poolsajand Teaduste Akadeemias (Half a Century of Estonian Philology at the Academy of Sciences) (1997), and an interview with him was published in the journal Mäetagused in 2008, on the occasion of his 80th jubilee. However, there are still people who knew him personally and could be interviewed.

I first met Ülo Tedre in 1964, so I knew him for half a century, although due to differences in the age and social status, I was never part of the circle of his closest friends.

However, in the autumn of 1963 Matti Kuusi launched a major Finnish-Estonian joint paremiological project, and Ülo Tedre as a representative of the Institute of Estonian Language and Literature at the Academy of Sciences of the ESSR was a member of the commission responsible for the work on the Estonian side. The primary task of the Tartu working group, under the lead of Erna Normann, was to compile a publication on Estonian proverbs. The imposed time limits were unrealistically optimistic, and we immediately faced difficulties, which required numerous discussion meetings with the participation of the leading committee and members of the working group throughout 1964-1966. This was when I first met Ülo Tedre, a middle-aged curly-haired stoutish man with spectacles, whose presence in the building was betrayed by the aromatic tobacco smell emanating from his pipe. He acquainted himself with our problems, and when in the autumn of 1965 we faced yet another crisis, it was him who resolutely suggested that we should replace the acting leader.

In 1969 our working group was practically dissolved, and I managed to start my post-graduate studies at the Institute of Estonian Language and Literature. The topic of my dissertation was a mixture of the image semantics, worldviews and classification of proverbs, and Ülo Tedre became my supervisor. At that time we were p r o b a b l y on a first-name basis with him, although it did not come so easily back then, even in the company of men, especially those with a different social status. I had some colleagues who worked side by side for decades and still addressed one another formally.

Tedre was not especially eager to speak about his personal life; yet, he repeatedly recalled suffering from lack of food at the university hostel (due to the post-war poor economic situation), and a banner with a motto "Aqua et panis - vita canis", which the 
students hung on the wall. When a hostel warden came and saw it, he commented on it: "Why are you hanging those English slogans here, better use Estonian ones instead!" Once we happened to walk through the old town, and I asked him something about a building that we were passing. He then told me the entire history of this house and continued with each following one on our way.

Ülo Tedre was a figure that our children found fascinating, with a beret aslant over his forehead, a pipe hanging from the corner of his mouth, always carrying a briefcase; he made contact with children easily and was called Uncle with a Pipe in our family. Ülo was constantly reading something. He lit his pipe to the morning coffee, grabbed a random book from the shelf, and sometimes read it for hours.

In September of the year of the Chernobyl catastrophe, 1986, there was a folklore conference at the Institute for World Literature in Moscow, and the pair of us represented Estonia. They accommodated us in the hotel Akademicheskaya, which was a nice one, but we were warned that the walls were 'micro-concrete' (full of microphones), so we were trying to keep our evening conversations under control. I remember that we could not keep to the conference schedule at all, and instead of planned presentations we had fierce arguments about structuralism and semiotics and whether they were useful or senseless in folkloristics. During intervals everybody gathered around the Ukrainian participants to enquire what had happened and what the situation was like. In the afternoons we walked around in Moscow, admiring the abundance of bookshops, snooping around at second-hand booksellers, but mainly bought coffee beans by kilograms, later to be distributed to our Tallinn and Tartu colleagues, as in the second year of perestroika this delightful substance had disappeared from Estonia altogether.

In 2014, Tellervo Krogerus published an 856-page book titled "Sanottu, tehty: Matti Kuusen elämä 1914-1998”, to mark the 100th birth anniversary of Matti Kuusi, a Finnish folklorist, paremiographer and paremiologist. The author who could publish - if not earlier then in 2028 at the latest - a book of a similar volume titled "The Life of Ülo Tedre (1928-2015)", may already be visible in the arena of folkloristics, but maybe not yet.

Arvo Krikmann 


\section{NEWS IN BRIEF}

\section{MAGIC IN THE RITUAL YEAR}

On September 25-27, 2014, the 10th annual international conference of the Societé Internationale d'Ethnologie et de Folklore (SIEF) Working Group on The Ritual Year took place in Innsbruck, Austria. It was organised by the University of Innsbruck and the Institute for History and European Ethnology with the Organising Committee consisting of Leander Petzold (chair), Tatiana Minniyahmetova, and Kamila Velkoborská.

The fascinating topic of the conference, "Magic in Ritual and Ritual in Magic", the hard work of the organisers and, probably, the magic of the location (Innsbruck in the Alps) resulted in 120 paper proposals. For a variety of reasons, not everybody who had submitted a topic were able to participate, but still 72 people from 28 countries came to the conference and delivered their papers. Many of the participants were taking part in the series of annual conferences of the Ritual Year Working Group for the first time. For example, 15 first-time Russian scholars came from different cities of the Russian Federation and spoke on various ethnic traditions, including the archaic traditions of the Russian North. Actually, dozens of traditions were discussed in the conference papers including European, Latin American, North American, Asian, and African ones. The development of magic was also traced from prehistoric times through early Christianity up to the present day.

After the ceremonial opening of the conference and the greetings by the organisers and the hosts, the plenary session started. The first five presenters initiated discussions on various aspects of magic in the ritual year and on magic as such. The first speaker, with a paper titled "The Cosmic Connections of the Eight Key Points in the Indo-European Ritual Year", was the President of the Ritual Year Working Group, Emily Lyle (Scotland), who shared her views on the division of the year as connected to cosmic structure and reflecting divine and heroic myths, life circle events, and colour semiotics. Marlene Mifsud-Chircop (Msida, Malta) delivered a paper on Good Friday rituals in contemporary Malta, in which she covered the history of religious processions and performances in the capital and other cities, emphasising the changes in the scenario of Maltese Good Friday during the last decades, which she has witnessed herself and studied as a folklorist and ethnologist.

Terry Gunnell (Iceland) introduced the theme of Neo-Pagan and New-Age movements, which have spread widely in recent times. His presentation, "The Background and Nature of the Annual and Occasional Rituals of the Ásatrúarfélag in Iceland", showed the origin, history, and modern ritual and social activity of a very popular Icelandic group, worshipping ancient Norse gods. Interviews with the priests and analysis of the prayers and activities raised questions regarding the source of decisions: who actually prescribe the magic acts and to what extent they can be regarded as designed by the priesthood and the members of the group. Éva Pócs (Budapest, Hungary) in her lecture "The Living and the Dead at the Time of the Winter Solstice in Central Eastern European Beliefs" analysed the functions of food and fasting during the most sacred periods of the year. According to this scholar, the archaic pre-Christian semantics of restraint from eating is actually an offering to the gods. Finally, the paper by another prominent Hungarian 
folklorist, Vilmos Voigt (Budapest), "Rebus - Charms - Evil Force - Magic", stressed the importance of studying verbal magic acts and their connection with evil spirits.

After the plenary session, parallel panels started. Some of them did not deal with the ritual year, which is at the core of the activity of the Working Group, but concentrated on magic itself and its distinctive features. The following presentations can be listed as examples of classical complex studies of magic in the ritual year: Evy Johanne Håland's (Greece) "Magical Ceremonies during the Ritual Year of the Greek farmer"; Betea Raluca's (Germany) "Magic Practices for Stealing the Milk of Animals: A Case Study on the Romanian Villages in Transylvania (18th-19th Centuries)"; Katya Mihaylova's (Bulgaria) "Andrzejki and Katarzynki in Polish Ritual Year"; Yulia Krasheninnikova's (Russia) "Magic of Holy Thursday in the Modern Tradition of Peasant Population of the Russian North"; Ekaterina Iagafova and Valeria Bondareva's (Russia) “Traditional Rituals in Modern Festive Ceremonial Culture of the Chuvash". The papers were based on unique personal field material, collected in archaic Slavic and south-east European zones, which show excellent preservation of the rituals. All these papers dealt with reconstructions of old magic acts aimed at fertility, the health of cattle and rich crops, as well as at driving away evil spirits and witches.

Another group of papers followed the initial theoretical guidelines of the Working Group - to study parallelism between calendar and life circle rituals. Iryna Koval-Fuchylo (Ukraine) in her lecture "Ukrainian Calendar Cry: Magic Value and Functional Features of the Tradition" analysed lamentations for the dead carried out on certain calendrical dates, especially on the Saturday before Whitsun. Similar parallelism, but on the basis of other traditions was studied by Rasa Paukštytė-Šaknienè (Lithuania). In her lecture "Ritual Year of Godparents and Godchildren in Contemporary Society in Lithuania" she showed how the traditional roles of the godparents in the calendrical festivals, organised for their godchildren, are growing today and starting to spread to almost all the bigger feasts, not just Easter, as it used to be before. Nadezhda Rychkova (Russia) in her paper "Magic of Communications in Family Rituals of Russians" shed light on the communicative aspects of magic acts in the life cycle and their newest transformations.

Similar parallels between the life cycle and the calendar, but in another direction, were discussed in a panel dedicated to calendrical divinations. Certain periods in the ritual year are filled in with mantic magic acts, which are aimed at revealing the future life of a person. Such rituals in Lithuania, Greece and Russia were explored by Žilvytis Šaknys (Lithuania) in his presentation "Magic or Entertainment? Marital Divinations and Ritual Year in Lithuania", by Ksenia Klimova (Russia) in "Fortune-Telling in Modern Greek Ritual Year", and Nina Vlaskina (Russia) in "The Types of Divination Used by the Don Cossacks: Highlighting Areas of Distribution". The presenters showed a mixture of magic and entertainment in all the modern divination acts, with the domination of love mantic rituals. The magic for love, as was argued by Oksana Mykytenko (Ukraine) in her paper "Padlock and Key as Attributes of the Wedding Ceremony: Traditional Symbolism and Contemporary Magic (on the Material of the Slavic Tradition)", is still present and even developing in quantity and quality in Slavic wedding customs.

Other panels scrutinised various details and components of magic in the ritual year and beyond its frame. Sacrifice or offering as a powerful magic act was investigated in the paper by Aida Rancane on the motifs of sacrifice in the context of present-day search for spiritual experience, in light of traditions and innovations, and in the presentation by Billy Fhloinn (Ireland) on sacrificial magic and the twofold division of the Irish ritual year. 
Basic elements, such as water, air, fire and earth are used for magic techniques and were at the core of the investigation of many scholars. A special session was dedicated to fire, which, together with water, dominates in many rituals. Irina Sedakova (Russia) in her paper "Magico-Religious Symbolism of a Candle in the Slavic Calendar Rituals" showed the polysemy and multiple functions of a candle in church and domestic services. She showed the development of a candle into a universal visual symbol of a tragedy, death and commemoration as a result of commemorative acts and performances with the lighting of candles all over the world. Tatiana Minniyakhmetova (Austria) delivered a paper on ritual fire in the annual cycle of Udmurtian calendric customs, in which she provided an in-depth analysis of the magic functions of fire in this tradition, its usage for contacting the gods, cooking the ritual meals, divinations, etc. Urszula Wilk (Poland), who studies Spanish festive culture, devoted her presentation titled "The Valencian Festival of Las Fallas as an Example of Symbolic Violence" to an iconic local festival in Valencia, which is performed annually on March 19 and is based primarily on huge fire effects. Georgi Mishev (Bulgaria) provided an interesting lecture titled "Where do you come from, ashes? - I come from a clean place. Healing Magical Practices from the Region of Thracian Cult Centre Starosel, Plovdiv Province, Bulgaria”, which gave the audience insights into the Thracian roots of modern Bulgarian folk medicine based on the magic of fire and its products.

This conference demonstrated the growing interest of scholars of the ritual year in Neo-Paganism, new cults and occult groups. Seasonal magic is at the centre of NeoPagan activity and theory. Joanna Malita (Poland) in the paper "Magic in Everyday Life of a Polish Wiccan: Field Study" shared her festive and routine magic experience. Kathrin Fischer (Switzerland) in her lecture "Wicca - Cycle of the Season and Life: PreChristian Traditions?" offered a survey of the pre-Christian basis of Wicca. Morgana Sythove (Netherlands), as a practising Wicca witch, in her lecture "The Wheel of the Year - Seasonal Rituals in Wicca" analysed and documented her own and her group's magical activity aimed at global and individual prosperity.

Arūnas Vaicekauskas (Lithuania) in his presentation "Religion and Imagination: Magic in the Neo-Pagans' Activity" argued that the creative element is a must in any occult movement. The theme of creativity and religious-cultural issues was continued by Fehlmann Meret (Switzerland) in her presentation "The Earth's Unseen Powers of Growth Need to Be Nourished': On Images of Seasonal Pagan Rituals in Popular Culture". Regional forms of Neo-Paganism with archaic forms of animistic and zoonymic magic were investigated by Graf Franz (Austria) in "Magic Revisited? Contemporary Animistic Rituals within British Neo-Paganisms from an Anthropological Perspective", and Kamila Velkoborská (Czech Republic) in "Magic as Practiced by the Brotherhood of Wolves".

Many of the papers alluded to modern innovations in traditional magic practice or were concentrated on the development of new festivals. Mácsai Boglárka (Hungary) in her presentation "I Am a Tractorist - This Is My Feast!': Sabantuy as Post-Soviet Political Calendar Ritual" analysed the revival and modification of a traditional Muslim holiday in Bashkortostan after the atheistic decades in this former Soviet autonomous republic. Dalia Senvaityte (Lithuania) in her paper "Annual Holidays in Lithuania: Discourse in Press and the Reality of the Daily Life" compared the festive topics which are discussed in families and in the public mass media discourse. The internet as an important source and tool for a survey of modern magic in various Russian regions was the topic of Evgeniya Litvin (Russia) in her paper "The Ways and Conceptions of Internet-Magic Representation". 
The magic of food and eating was the object of several presentations. Katarina EkNilsson (Sweden) spoke on the folk belief and rituals related to bread in Sweden in the past. She was concerned with the historical transformation of sacred food, especially bread, in the Swedish folk tradition. Elena Popova (Russia) dealt with the topic "The Role of Ritual Meals in Modern Christmastide Customs of the Besermyans". Her investigation showed that the culinary and entertainment inspirations remain the most significant parts of Christmastide and other celebrations, even if the magic function has waned away. Apart from eating, drinking has also manifold magic functions. Sergey Rychkov (Russia) dwelt on the magic of toast, a verbal festive genre, which has not been investigated fully, neither in Russian, nor in other traditions. Mojca Ramšak (Slovenia) in her colourful presentation "Wine Queens' Rituals in the Service of Wine Marketing" demonstrated the transformation of magic activity into commercialism.

Masking and ritual dresses, theatrical performance and figurines also have magical purposes, as the scholars Konrad Kuhn (Switzerland) ("Wooden Carnival Masks between Magic Objects and Collective Representations"), Alessandro Testa (Czech Republic) ("The Re-Enchantment of Europe: Traditional Carnivals and the Belief in Propitiatory Magic (Two Ethnographic Cases from Italy and the Czech Republic)") and Celia Sánchez Natalías (Spain) ("Magical Puppets in the Western Roman Empire") showed in their papers. Laurent Sébastien Fournier (France) investigated another important component of festive life in his presentation "The Magic of Traditional Games: From Anthropological Theory to Contemporary Case Studies".

Different parameters of the magic acts and rituals, such as space, have also been central to the interests of scholars. Nadezhda Shutova (Russia) discussed ritual as a way of organising the sacred space in the Kama-Viatka region at the end of the 19th and early 20th centuries on the example of Udmurts. Cozette Griffin-Kremer (France) in her lecture "Is Doing Things Right, and the Right Number of Times, Magical? May Day and Maying Customs" reflected on the direction of movement as a magic technique in festive and everyday contexts. Andrey Khudyaev (Russia) ("Magic Ritual and Its Spatial Structure in Archaic Cultures of the North") and Jurij Fikfak (Slovenia) ("Magic - Sacred Chronotopes of Ritual Practices") touched upon theoretical issues of sacred space and its magic semantic.

Magic acts and a search for miracles based on folk religion were analysed in the paper by Irina Stahl (Romania) ("The Nine Miraculous Graves: Seeking Help from Beyond"), while Aigars Lielbārdis (Latvia) was concerned with the topic "Catholic Saints in the Latvian Calendar".

Folk astrology was investigated in the papers by Mare Kõiva and Andres Kuperjanov (Estonia), titled "The Moon, Astronomic Objects and Symbolic Rites in 20th-Century Healing Strategies", and Oksana Tchoekha's (Russia) presentation "Lunar Folk Magic in the Balkan Region".

A special panel was dedicated to plant lore and herbal magic. Aleksandra Ippolitova (Moscow, Russia) described rituals for picking plants in Russian herbal manuscripts of the 17th-20th centuries, and Svetlana Sidneva (Moscow) spoke on the magic herbs in modern Greek and Italian calendar customs.

The conference gave the floor to many scholars, including those who did not touch upon the ritual year and calendrical magic. History, folklore texts, literature, arts, and theology have all been investigated from the point of view of magic acts, reflecting and implementing pre-Christian pagan beliefs. Scholars dwelt on the image of the sorcerer 


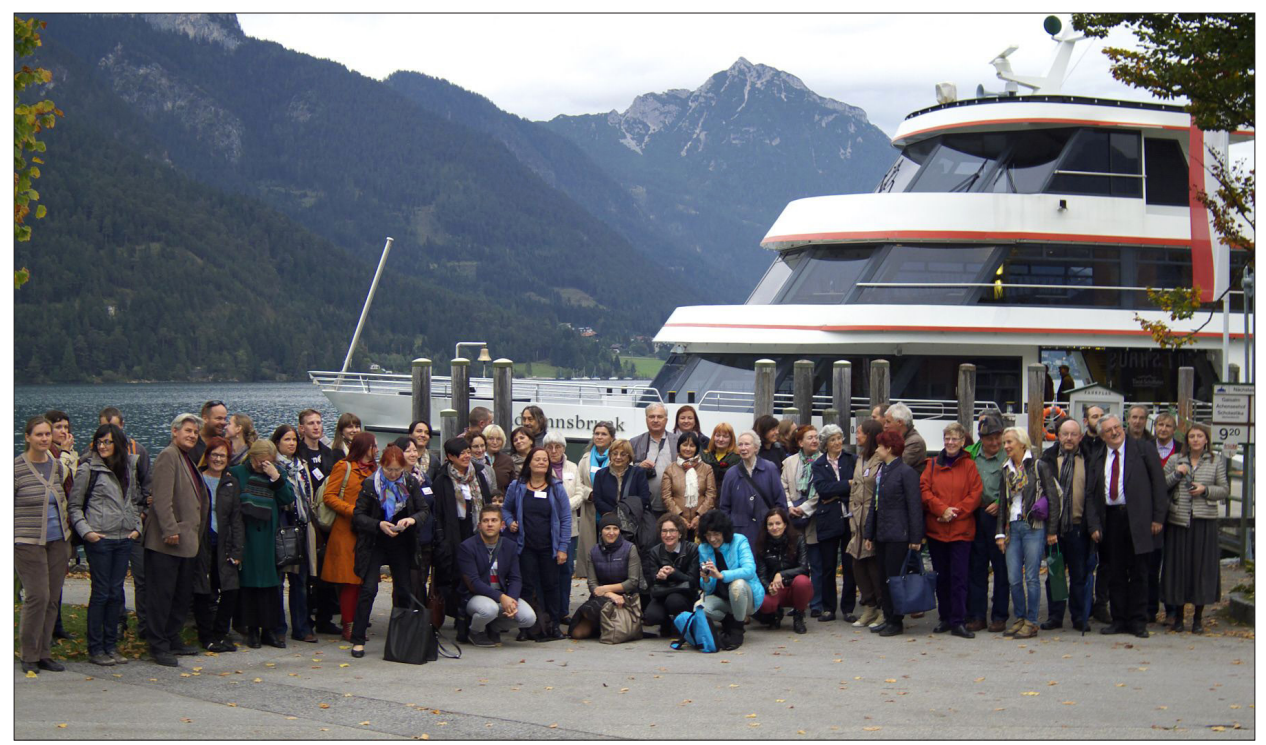

Conference participants at Lake Achensee. Photograph by Andres Kuperjanov 2014.

and the witch, on Shamanic traditions, on gender aspects of magic, and many other academic issues.

The Innsbruck conference celebrated the tenth jubilee of the Working Group on The Ritual Year. The founder and president of the group, Emily Lyle, asked to step down and retire from her position. The members of the group voted to apply to the SIEF administration for permission to grant to this outstanding scholar the title of honorary president of the Working Group on The Ritual Year. In accordance with the new SIEF bylaws, for the next two years the Working Group on The Ritual Year has elected two co-chairs (Irina Sedakova, Russia, and Terry Gunnell, Iceland), a secretary (Irina Stahl, Romania) and a liaison person with the SIEF administration (Laurent Sébastien Fournier, France).

The next (11th) conference of the Working Group on The Ritual Year will be held in Kazan, Russia, on June 4-7, 2015, and will be dedicated to the general topic "Traditions and Transformation". At the 12th SIEF Congress (Zagreb, June 21-25, 2015) the group will be represented by two panels, convened by Nina Vlaskina and Irina Sedakova (http:// www.nomadit.co.uk/sief/sief2015/panels.php5?PanelID=3462) and Irina Stahl (http:// www.nomadit.co.uk/sief/sief2015/panels.php5?PanelID=3409).

Irina Sedakova

\section{Acknowledgement}

Participation in the conference and this review was partly supported by the Presidium of the Russian Academy of Sciences (grant "Balkan Text in Ethnocultural and Ethnolinguistic Perspective", 2012-2014). 


\section{NATALIA ERMAKOV DEFENDED A DOCTORAL THESIS ON ERZYA LAMENTATIONS}

On October 15, 2014, Natalia Ermakov from the Estonian Institute of Humanities at Tallinn University defended her doctoral thesis titled Erzianskie prichitaniia: traditsii bytovaniia $i$ sovremennoe sostoianie (Erzya Lamentations: Traditions and Current Status).

This dissertation is the first comprehensive survey of the history and role of the lamentation genre in Erzya traditional culture conducted on the basis of the lore of a concrete region - Ardatovsky district in the Republic of Mordovia. As the author of the thesis has grown up amidst this tradition, she is the right person to collect and interpret the material. She presents interesting observations about the religious taboos concerned with recording lamentations and describes the differences between lamentations in an authentic situation and those used separately from rituals.

Natalia Ermakov's research is based on material interpretation and context analysis, and proceeds from different research methodologies. She has used genre, semantic and thematic analyses of lamentations. This research is especially topical as Mordvinian written culture is still young and oral heritage constitutes an essential part of culture, whereas the lamentation tradition is gradually fading. 49 of her informants are Erzyans and 5 are Mokshans, predominantly older women, but also 5 men. Part of them reside in Estonia. In addition, the researcher has obtained material from periodicals, literary sources, archives and the Internet.

The author gives an overview of the historical research of Mordvinian lamentations, pointing to the features common with the tradition of other Finno-Ugric peoples. Both funerals and weddings are rites of passage; therefore the respective rituals and lamentations of different nations are largely similar.

The author emphasises that each lamentation is unique, and every time each lamenter, by using traditional elements, creates something unique. Lamentations have magic, psychological, social, ritual and artistic functions. Artistic imagery plays an important role in the structure of lamentations. Poetic imagery involves epithets, personification, alliteration, and synonymic repetitions. Part of the formal features of lamentations, such as alliteration and synonymic parallelism, are inherent also in Balto-Finnic lamentations and runo songs. A more general feature of lamentations is the monologue.

The chapter titled Archaic Components of Erzya Lamentations as a Source of Mordvinian Ritual Culture Research analyses early historic features that have survived especially in ritual funeral customs. Here the author of the thesis describes interesting funeral customs, which imitate the unrealised weddings of the untimely dead, using a "replacement", as well as the international custom of passing on the bridal chaplet to the next potential bride.

A separate chapter analyses traditional elements and changes in lamentation tradition on the basis of the material obtained from the villages of Ardatovsky district. The author states that today old funeral customs have been replaced by new ones; yet, people still believe that the deceased for whom funeral rituals have not been performed, can turn into the "dangerous dead". 
Mourning motifs in lamentations are intertwined with religious motifs, which in turn mix pre-Christian with Christian and old funeral customs with church rituals.

A separate chapter is dedicated to ancestral cult (incl. the 40-day commemoration period), which is based on the belief in afterlife and ancestors' ability to influence the fate of the living. The cult features special prayers and sacrifices.

Ermakov also refers to Mordvins and Mari's peculiar coffin with one or several openings, through which the spirit of the deceased could ascend to the ground. This must be a pre-Christian common feature of Finno-Ugrians, as it can also be observed in Carelians, Setos, etc.

A separate mention is made of wedding rituals and lamentations; the latter were performed, besides the bride, also by her mother, friends and other relatives. In case the bride was not able to lament herself, she was replaced by someone else.

The dissertation describes individual stages of the wedding (proposing, preparations, bridal sauna), and the respective bridal lamentations. The sauna ritual was related to the belief in the cleansing power of water and the magic influence of the sauna. The Mordvinian bride expressed her gratitude to the sauna fairy with her lamentation; she also lamented to next of kin when she had to leave home. In Mordvinian bridal lamentations pagan gods are also thanked for their expected help in future life.

In conclusion, the author observes that in the course of time changes occurred in wedding rituals, whereas part of them were preserved in their old form, along with respective beliefs, whereas some others lost their original meaning but were preserved as ritual elements, and yet others turned into wedding jokes.

A separate mention is made of draftee and soldier lamentations, which are said to have emerged already before Peter I enacted the conscription law in Russia in 1699. These lamentations are largely similar to death lamentations; they reflect social and political circumstances and feature Russian influences. The tradition of lamentations was revived with each subsequent war, in which Mordvinian young men had to participate.

Side by side with ritual lamentations, non-ritual ones also spread. These reflected people's personal destinies and hardships of life, and integrated pagan customs and beliefs, orthodox influences, reflections of the surrounding reality, language specifics and continuity of generations. Here we could agree with the author's opinion that they only emerged in the cultures in which ritual lamentations occurred.

In the conclusion the author maintains that lamentations constitute an essential part of Mordvinian culture, and, in addition, they also carry ethnic identity and unite the community and the nation. While death lamentations have survived until today, draftee lamentations have re-emerged in critical periods, and wedding lamentations are no longer used. The reason why old traditions fade away lies in the influence of neighbouring peoples and Orthodoxy, social and economic development, as well as increasing urbanisation and overall globalisation.

Natalia Ermakov specifies three tendencies in changing rituals: reverting to old traditions (death lamentations), modernisation (using lamentations in new forms outside rituals, which used to be a taboo), and fading away (wedding lamentations have nearly disappeared even in villages). In order to foster the preservation of folk culture, the mother tongue and folk culture are taught at kindergartens and schools, and old traditions are kept alive by amateur groups as well as in professional culture - theatre, concerts, etc. 
The dissertation is highly interesting due to the abundance of authentic empiric material, which is described, interpreted and construed. The author's conclusions are reliable as she is part of the studied community. However, she has also been able to distance herself as a researcher, combined empirical sources with theoretical works, and presented parallels with the cultures of other nations.

The dissertation offers novel, interesting, and valuable information both for folklorists and representatives of neighbouring sciences, especially for researchers of folk belief, rituals and lamentations. It is also an inestimable source of information and valuation of Mordvinian culture for each representative of this nation.

Ingrid Rüütel

\section{SEMINAR ON DIGITAL HUMANITIES AT THE ESTONIAN LITERARY MUSEUM: INFOTECHNOLOGICAL INNOVATION IN HUMANITIES AND EDUCATION}

A seminar titled Digital Humanities in Estonia: Infotechnologocal Innovation in Humanities and Education took place on October 27 and 28, 2014, at the Estonian Literary Museum. A year before, a seminar on digital humanities had taken place for the first time, and now a tradition is about to be created. The two-day event featured both presentations and workshops and aimed to give an opportunity for humanities researchers to share their competence and experience in digital methods and learn from the others.

On the first day, October 27, presentations about various topics were given. The seminar began with the presentation of the webpage and publication based on the papers given a year before. Both of these are available in Estonian and in English at http://www.folklore.ee/dh/en/dhe_2013/. One of the main topics was concerned with various databases and research opportunities created by them. Anu Lepp from the University of Tartu introduced the water mark research and gave an overview of how to use the database of early Estonian prints (http://paber.ut.ee/EN/vesimargid/), which is connected with Bernstein: The Memory of Paper watermark database that displays watermarks from different regions of Europe. Marin Laak from the Estonian Literary Museum introduced the digitisation project of Estonian literary classics, through which 87 books will become freely available as e-books. The choice of books is determined by the compulsory reading lists of schools as well as copyright issues. Ülo Treikelder from the Tartu Public Library spoke about the database Tartu in Fiction (http://teele.luts. ee), which contains excerpts of poetry and fiction that describe Tartu. In this database data can be searched by names, locations, time-related or general keywords. Maps and photographs are being added as well. Interest in place-related texts has also spread in other disciplines. Kaisa Kulasalu from the Estonian Literary Museum gave an overview of how folklore texts and multimedia related to places in Estonian national parks have 
led to an online map application on the web map server of the Estonian Land Board. The difficulties with academic open access web journals and the publishing process in such journals were mapped by Mare Kõiva and Andres Kuperjanov from the Estonian Literary Museum. The discussions about databases and websites showed that displaying digital content online has brought new sets of problems, but, at the same time, also opened new paths for research.

One of the new possibilities created by massive amounts of digital content is crowdsourcing: people can work with archive collections online, adding information in a way that is interesting for them and useful for the memory institutions. Maive Mürk from the National Archives of Estonia introduced the new crowdsourcing portal that gives an opportunity to work with materials about the First World War. Another crowdsourcing platform called Timepatch (in Estonian: Ajapaik (http://ajapaik.ee/)), however, is not created by a particular memory institution; instead, the site uses photos from different institutions, users can geotag and rephotograph them. In creating a site like that, good standards for digitising and data exchange across memory institutions are essential.

In addition to discussing the existing projects and platforms, some papers pondered upon new research perspectives. Mari Sarv from the Estonian Literary Museum introduced the methods of social network analysis and showed the benefit thereof in analysing Estonian folk songs. Raivo Kelomees from the Estonian Academy of Arts described the artist multimedia projects from the 1990s. Big changes in both hard- and software mean that it is very difficult to display these pieces of art. Therefore, a good archiving solution is definitely needed.

The day ended with a discussion about the current state and developments in Estonian digital humanities. The seminars and workshops could take place more often and in different locations. The dialogue between humanitarians and programmers should be seen more in events like this, although attracting the interest of programmers needs different means of communication. There is also a need for further collaboration in the field of education. Especially in this regard, questions of functionality, design, and user experience should not be neglected.

Tuesday, October 28, was filled with workshops. The day began with the workshop “Text corpora: Analysing tools and possibilities". Kadri Muischnek displayed a simple analysis of texts using the Linux operating system. This was followed by Liina Lindström and Kristel Uiboaed, who showed the tools they had used for analysing Estonian dialects. Software can be of considerable help in formalising, visualising and analysing various kinds of humanities data. In the afternoon, Hembo Pagi held a workshop about RTI (Reflectance Transformation Imaging) photography. This is a computational photographic method that is excellent for studying cultural heritage materials; the surface shape and colour are seen in detail through interactive re-lighting of the object from any direction. The object should be lit from different angles, and the equipment for this includes a camera, a separate flash, a small sphere, and a piece of string.

The seminar about digital humanities helped to form a community and learn from each other. The tradition of analysing research in the framework of digital humanities is rather new in Estonia, but the network is gradually forming. Among other disciplines, folkloristics definitely benefits from this.

Kaisa Kulasalu 


\section{ESTONIAN FOLKLORE, CULTURAL HISTORY AND LITERATURE IN A DIGITAL FORM: THE FILE REPOSITORY AND ARCHIVAL INFORMATION SYSTEM KIVIKE}

In the past years, Open Data, Open Access and Open Government have become buzzwords in media and in the discussions about the information systems of various institutions of Estonia. From the beginning of 2015, the sets of open data in Estonia have been gathered to a web portal https://opendata.riik.ee/.

Among other datasets, the user can find the collections of the Estonian Literary Museum. The European Regional Development Fund (ERDF) has been financing the project "Open Data at the Estonian Literary Museum", which has made a huge amount of data about folklore, literature and cultural history available for wide audiences. As of 2012 , the file repository and archival information system Kivike (http://kivike.kirmus. ee) has enabled those interested to use the digital collections of the Estonian Literary Museum. The goal of the museum and its departments (the Archival Library, Estonian Cultural History Archives, Estonian Folklore Archives, Department of Folkloristics, Department of Ethnomusicology) is to preserve and study materials related to Estonian culture. The online repository and information system Kivike is essential for preserving digitalised and born-digital materials and making them available for wider audiences.

The metadata of the collections of the Estonian Literary Museum have been described in different indexing systems. Card catalogues are still widely used, but in the 1990s the practice of describing data in digital format evolved. The metadata of folklore collections were described in different formats, and so were the transcriptions. Folklore collections were made available to wider audiences in their home computers via a variety of online databases. The new materials were described in different formats. With the help of the ERDF funded project, Kivike as the archival information system gathers all this information in one environment and makes it possible to search all the sets of digital metadata related to a certain area or person. For specific genre-related searches, the specialised databases offer better options, but the general overview of all of the materials is better in Kivike. There are different search options: from a very simple one-field-search to advanced queries. By now, there are more metadata descriptions than files in the repository. The amount of descriptions makes it possible to place orders for the files that are not yet digitised.

The language of the repository is Estonian, as well as the majority of the data; yet, there are exceptions: for instance, in folklore collections there are materials in other Finno-Ugric languages, as well as in German and Russian. Music, photographs and videos may possibly be interesting for international audiences. Already now, Kivike has been used in 52 countries, Germany, Finland and the United States, being among the top three. The users are likely to be part of Estonian diaspora. For the future, usage possibilities in English and Russian are being planned, as well as the representation of the collections in Europeana.

Kaisa Kulasalu 


\section{INTERNATIONAL WINTER SCHOOL "CIRCULATION AND COLLABORATION: PERSPECTIVES FOR/IN INTERDISCIPLINARITY”}

One of the factors in establishing the position of the humanities in the research landscape is interdisciplinarity, i.e., purposeful perception and application of diverse possibilities and search for new cooperation forms and opportunities. Cooperation requires both learning and teaching, but also a pragmatic basis in the form of economic and institutional leverage. The Estonian Graduate School of Culture Studies and Arts (GSCSA), established in the autumn of 2009, is supported by the European Union Structural Funds and integrates graduate students of the humanities and their supervisors from the University of Tartu, Tallinn University, the Estonian Academy of Arts, and the Estonian Academy of Music and Theatre. The graduate school covers more than a dozen curricula and organises over twenty interdisciplinary scientific events annually. Institutionally, the graduate school cooperates with the Estonian Literary Museum, the Under and Tuglas Literature Centre of the Estonian Academy of Sciences, the Estonian Arnold Schönberg Society, the Center of Modern Humanities (Zentrum für Theorie und Methodik der Kulturwissenschaften) at the University of Göttingen, and the Centre of Excellence in Cultural Theory in Estonia. In addition to smaller and more specifically oriented intensive seminars, the majority of graduate school members get together for the annual winter school, which is alternately organised by Tartu and Tallinn Universities. Different fields of research are integrated in view of a diverse selection of courses on cultural analysis and involvement of foreign competence; yet, bearing in mind similar theoretical and methodological problems.

The 5th International Winter School organised jointly with the Centre of Excellence in Cultural Theory, under the heading "Circulation and Collaboration: Perspectives for/ in Interdisciplinarity" took place in Tartu on February 2-6, 2015, and attracted more than a hundred researchers and graduate students. The winter school focused on the keywords 'circulation' and 'collaboration', as well as cooperation opportunities between different disciplines, and issues concerned with the visibility of research results. We witness today a growth of networks, new infrastructures and channels, which circulate knowledge and in which information moves with previously unthinkable speed. A critical consideration of the processes of circulation and cooperation, as well as crossdisciplinary theorising and methodological discussions on the issues involved provides us with innovative analytical space for both synchronic and diachronic research. The seminars and workshops of the winter school discussed the advantages and benefits of interdisciplinary cooperation, but also pointed out possible obstacles; for example, it was stated that taking over theories, methodologies or terminology of another discipline may suggest innovative symbioses but also pose problems in understanding, for which we should be prepared.

The winter school programme included lectures by Estonian and foreign academics, targeted at a wider audience, as well as workshops in smaller groups, with in-depth discussion of the topics presented in lectures. One of the days was dedicated to practical group work, with a choice between four topical themes. A workshop led by anthropologist Laura Siragusa (University of Tartu / University of Aberdeen) discussed publishing opportunities for early career researchers; the participants were able to test different 


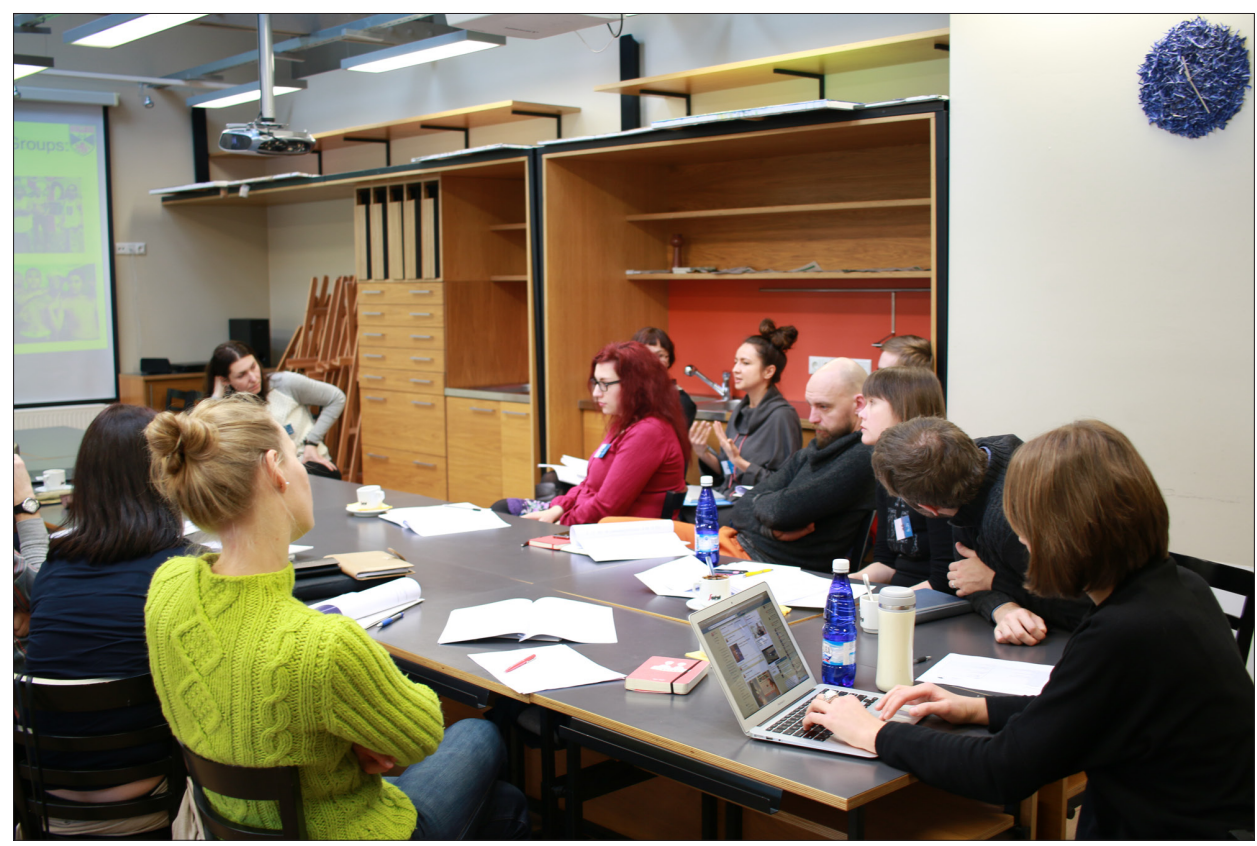

Collaboration in a workshop. Photograph by Aivo Põlluäär.

ways of interdisciplinary research involvement while being also prepped by editors-inchief of two journals, Journal of American Folklore (Thomas DuBois) and Journal of Ethnology and Folkloristics (Ergo-Hart Västrik), who gave an overview of the editing process of scholarly articles. The workshop participants came to the conclusion that both in the framework of one or in cooperation between several disciplines one of the most challenging and unpredictable aspects is the compatibility of concrete researchers.

The workshop "Digital Humanities: Data and Metadata from a Semiotic Perspective" demonstrated points of intersection between semiotic data models and digital approaches. Indrek Ibrus (Tallinn University) spoke, in a Skype presentation, about the digitisation plans of Estonian film heritage in the context of similar developments in Europe and analysed the addition of metadata from a semiotic viewpoint. The groups led by Katre Pärn (University of Tartu) discussed the metadata sought by different user groups and possibilities for their mediation. The ever-significant issues of ethics and morality in the context of interdisciplinary research were taken up in the workshop run by Stavroula Pipyrou (St. Andrews University) and Daniel M. Knight (Durham University). Among other things the participants discussed ethic dilemmas that are confronted when conducting anthropological research among controversial social groups, such as right extremists or imprisoned criminals. The workshop led by Monika Tasa (Centre of Excellence in Cultural Theory) dealt with the issues concerned with making qualitative research visible, understandable and available.

All the lectures with their following discussions, as well as seminars, offered an inspiring range of ideas and approaches. Matti Sintonen, Professor of Philosophy 
at Helsinki University, delivered a more general theoretical lecture on interdisciplinarity in the humanities. The lecturer noted that arguments arise already when defining the research discipline, as new disciplines and discipline conglomerates keep emerging due to professional, institutional and financial reasons. Sintonen suggested that we should speak about research fields rather than disciplines. Also, the lecturer maintained that interdisciplinary cooperation is understood in different ways: either by continuing everyday work under the umbrella of a collaboration project or by formulating new common objectives and gaining scientific added value with the help of newly elaborated theoretical and analytical framework. Regina Bendix, Professor of European Ethnology from Göttingen University, also pointed out the primary challenge of finding consensus during the process of interdisciplinary collaboration. She contended that although the funding policy usually favours innovative forms of cooperation between different research fields, in the case of malfunctioning collaboration the project partners have to cope with arising problems on their own. On the other hand, the complex cultural and communication networks of the globalising world feature an increasing number of research issues, which require the contribution of more than one discipline. In order for researchers to better understand the expectations and resources of their cooperation partners, distinguishing between different ways of cooperation (e.g. multidisciplinary, transdisciplinary) is needed from the very beginning.

The presentation of Penelope Harvey, Professor of Anthropology from Manchester University, focused on the 'political economy' of materials and material agency, as well as their potent vitality, including animistic attitudes related to them. Harvey suggested that here we can speak about collaboration between material and its shapers, as the communicative aspect is mutual in such interaction. Using the example of stone and concrete, she showed how the same material conveyed different messages in different eras; for instance, symbolising strength, power and perpetuity, but also corruption and decline.

Alexei Yurchak, Associate Professor of Anthropology at the University of CaliforniaBerkeley, gave an intriguing lecture on the 'bodies' of Lenin, which, to a certain extent, touched upon similar issues. He provided a captivating visual demonstration of how depictions of Lenin and metaphors used in political rhetoric (e.g. the rhetoric of the utmost truth) were in correlation with social changes. Notions of Lenin as the embodiment of wisdom and morality started to crumble only as late as during perestroika, when facts about his sexual orientation, illnesses, nationality, and financial sources were gradually disclosed. Yurchak proposed an ultimate deconstruction of Lenin's cult to have occurred in a TV show which linked Lenin's fondness of mushrooming to consuming their psychedelic properties, with a conclusion that thus the entire October Revolution and the subsequent Soviet regime had been based on perceptual anomalies. The postlecture discussions drew parallels between the cults of political dictators and religious leaders on the example of the motif of rebirth and resurrection and the widely spread religious custom to honour, instead of the physical relics of spiritual leaders, the texts authored by them. The following seminar continuing on this topic ran an hour longer than scheduled, with endless questions about current political issues. It was debated whether Russia, an enormous country from remote villages to huge metropolises, should be treated as a uniform research object. Yurchak considered it feasible because the juridical framework and economic opportunities or restrictions are nevertheless the same. 
Pärtel Piirimäe, Associate Professor of History at the University of Tartu, spoke about the historical evolution of the perception of 'own' and 'alien' in nations and ethnic groups, discussing civilisation and barbarism in early modern international law. Piirimäe maintained that international law well reflects the attitudes and ideals of the era. Since the very beginning, international law has been an interdisciplinary sphere, as in its early days, in the 16th century, it was thought to be the domain of theologians, and later on that of philosophers; by advocating the idea of the superiority of civilised people natural sciences were also referred to. Piirimäe emphasised that the labelling of non-European peoples as 'barbarian' did not necessarily present justification for their colonisation but could rather have been the way they were subjectively perceived by their colonisers. Examples of depicting the adversaries as barbaric and incapable of development were also presented from present-day military conflicts.

Similar mechanisms have also determined attitudes towards minorities more recently and, as was shown in the presentation by Thomas A. DuBois, folklorist and Professor of Scandinavian Studies at the University of Wisconsin-Madison, on the example of the North-American Chippewa/Ojibwe/Anishinaabe or the Scandinavian Sami, representatives of these peoples contest but also argue about the prevailing stereotypes and representations. For instance, they disagree about whether the use of modern electrical tools in making traditional artefacts marks the decline of old culture or, vice versa, its vitality and capability to evolve. In his following seminar DuBois introduced the use of the new media (e.g. Internet forums, social media communities, digital gaming) for the purposes of preservation and revitalisation of the identity and culture of ethnic minorities, illustrating it with colourful examples.

Lars Elleström, Professor of Comparative Literature from Linnæus University, discussed old and new communication forms from the point of view of intermediality. The lecturer interrogated why certain communication forms are flexible and easily transmitted to other media, yet some others are not. Elleström suggested theoretical means for studying different communicative situations and phenomena.

Martin Stokes, Professor of Musicology at King's College London, contemplated about music as a creative form carrying a communicative message, or, more specifically, expressive ways of sentimentality in the music of different cultures. Often the medium for expressing feelings in a concrete culture is an instrument of iconic significance (e.g. the accordion in tango music), manner of performance, or body language (e.g. in Portuguese fado). Among other things, Stokes highlighted era-specific changes in expressing sentimentality. For instance, in the 1950s singers were reproved for using the microphone because it distorted the voice and authentic expression of feelings, whereas today electronic distortion and artificiality are characteristic of certain popular music trends and artificial sound is in turn a means to express the moods inherent in the style.

In addition to lectures and seminars, the winter school offered opportunities for socialising and establishing new contacts, hopefully forming a basis for some future interdisciplinary collaboration projects.

Reet Hiiemäe, Kristin Kuutma 


\section{BOOK REVIEWS}

\section{TRAVELS OF AN EXILED WRITER}

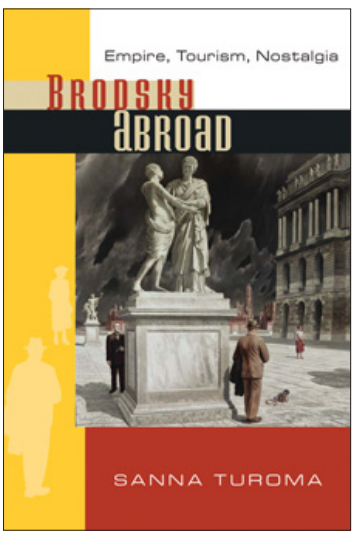

Sanna Turoma. Brodsky Abroad: Empire, Tourism, Nostalgia. Madison, Wis. \& London: The University of Wisconsin Press, 2010. 292 pp.

This is a book about the Nobel Prize awarded Russian poet Joseph Brodsky's travels after he was expelled from the Soviet Union in 1972. Brodsky was born in Leningrad (now St. Petersburg) in 1940 and died in New York after a heart attack in 1996. He has retained a prominent status for people who appreciate Russian and classic world literature.

The author, Sanna Turoma, is a senior researcher at the Aleksanteri Institute (University of Helsinki), Academy of Finland, and the book is based on her doctoral dissertation.

Due to his oppositional stance, Brodsky was repressed in the Soviet Union, sentenced, and later on 'strongly advised' to emigrate. After settling down in the USA and pursuing various academic and nonacademic jobs, he had the opportunity to travel around the world. These travels were reflected in his poems, and Sanna Turoma has written a book where Brodsky's writings about four locations - Mexico, Rio de Janeiro, Istanbul and Venice - are scrutinised. As a comparison, Brodsky's pre-emigration period poems and essays about his native Leningrad are analysed in the second chapter.

The focus of the book is defined on the fifth page: "The book aims at setting Brodsky in a dialogue with leading representatives of postcolonial and postmodern theories in order to recontextualize the scholarly investigation of his travel poetry and prose." In short, Turoma looks at how places are contextualised and interpreted depending on their cultural and social meaning for Brodsky. Attention is concentrated on how Brodsky links different locations with culture, religion, or history, and how the description of a visited place depends on how the poet positions himself, his cultural background and origin. The self-positioning of Brodsky was determined by different markers; he carried with him the burden of being an emigrant from the Soviet Union who never really adapted to the West. In his travels outside Europe, Brodsky also encountered cultures that were non-European or non-Christian - factors that also changed his selfpositioning. The personality and biography of Brodsky is so intensively reflected in his poems that by reading this book I came to realise that the monograph could be seen as a psychoanalytical treatise through travel writing.

The book certainly reveals much about Brodsky's ideas and attitudes through his poetry. By looking at the travel poetry, one perception of the author is that travel writing as such has its roots in colonialism, in the period when Western nobles travelled outside Europe and described the countries they visited as the Other, from the perspective of Orientalism (p. 56). Brodsky, who grew up in Leningrad, had similar attitudes. His writings from that period reflect his strong nostalgia for the empire combined with the 
Soviet 'kitchen dissidents', typical of piterskie (St. Petersburg) intellectuals (p. 69). This imperial nostalgia was apparently also the reason why Brodsky was always hostile to contemporary art and architecture (p. 58). In his later years Brodsky published several poems and essays idealising Leningrad/St. Petersburg's 'magnificent' past (p. 76), even comparing it to the British Empire. In the last pages of the chapter about Leningrad, Turoma introduces another aspect in Brodsky's philosophy: constant attempts to define Russian national identity, rooted in the imperial past expressed in the architecture of the 'old Petersburg'. These few pages help to explain why Russian émigrés often failed to adapt in the West. Notwithstanding their anti-Soviet regime stance, they identified themselves with the culture of a country with a great history and significant influence on the world. Turoma here finds traces of post-colonial nostalgia and self-identification with a great empire that has ceased to exist.

Turoma views Brodsky's interpretation of other countries through the eyes of the piterskii intellectual who never felt comfortable in, and never fully accepted, other cultures. "From Brodsky's metropolitan Soviet viewpoint" (p. 86) Mexico resembles the Soviet Central Asian republics with its exotica, underdeveloped economy, poverty, and inheritance from a long destroyed native empire. In his poetry, Brodsky takes a strong anti-colonial position condemning the Spanish and American colonialism that destroyed the natives' dignity, languages and traditions. Turoma draws on other Russian Soviet poets like Mayakovsky and Blok in order to demonstrate how the discourse of "Euroimperial" and "Russian imperial knowledge" (p. 92) has changed over time. Brodsky's position is definitely more critical of contemporary Western politics. What makes Brodsky's 'Mexican cycle' different from writing about other places is that he obviously studied the history of the country and the biographies of its rulers. There is a difference in the poet's position on Brazil, described by Turoma as "the Metropolitan man in the Third World". The Brazilian writing is even described by Turoma as an "anti-travelogue" ( $p$. 108). Brodsky is disappointed by the "amnesia" (p. 108) he encounters: the past has been wiped clean and the country is trying to modernise itself by building European style cities, roads and large-scale blocks of flats. For Brodsky, Rio de Janeiro appears as a model for future European decay: boring, monotonous, promiscuous, a "jungle" dominated by poverty (pp. 110-111). The Third World perspective is prevalent here: Rio wants to be Europe but fails, it is too backward. However, Istanbul receives a different treatment. Turoma finds in Brodsky's writings his love of the city's classical Orientalism: a former capital of the Ottoman Empire, architecture that resembles past victories and once led the world culture. Simultaneously, Istanbul embodies the "Eastern savagery" (p. 139), being erratic, violent, and dirty. Brodsky places Turkey in the Russian imperial framework, seeing it as Caucasian (kavkazskii) or Eastern (vostochnyi). This discourse seems to be more comfortable and understandable for the poet. Istanbul reflects the uneasy relationship that Russian intellectuals have with Soviet Caucasian and Central Asian republics, in which admiration for impressive cultural and historical inheritance is fused with the arrogance of the culturally and technically superior Christian conqueror. In the travelogue about Turkey, Brodsky slightly gets personal and biographical, comparing Istanbul/Constantinople with St. Petersburg/Leningrad. The chapter about Brodsky's writings on Venice starts with a brilliant overview about the ambivalent place this city occupies in the 19th and 20th century Russian travelogues. Venice is simultaneously the home of classic European culture and a symbol of European decay with dilapidating palaces and monuments. This chapter is worth reading due to the polemic about Brod- 
sky's place in Western literature where he remained "marginal" but not a "marginalised" writer (p. 159). The chapter about Venice also contains more biographical information about Brodsky. In short, this section of the book helps to localise the Russian émigré's disillusionment with the West, where he gained quite a prominent position as a public figure.

Sanna Turoma's book is theoretically well founded and brilliantly analytical. It is not only about Brodsky; it also skilfully reflects his status in the Soviet Russian poetry tradition, with references to other Soviet Russian poets like Mayakovsky, Tsvetaeva, Akhmatova, Mandelstam and Blok. Turoma shows the inner confusion of Russian poets about the era where they were unable to find a clear position between the oppositional stance, euphoria about the Soviet might and progress, and nostalgia for the Tsarist empire with its high culture. Currently, when the national soul-seeking of Russian poets and writers has become prominent in Russian mainstream newspapers, the book gives a glimpse into the way of thinking by which such people seem to be influenced. The book is also a great contribution to existing literature about postcolonial writing by showing another angle: the Eastern European emigrant perspective on the Western cultural and economic dominance they wish to deny. Turoma's monograph, however, would have needed more biographical information about Joseph Brodsky at the beginning of the book. Many crucial facts of the poet's life are mentioned throughout the book but, unless the reader already knows who Brodsky was, they can find other sources for a more coherent biography of the poet.

Aimar Ventsel

\section{ISLAMIC CIVILISATION AND MUSLIM NETWORKS}

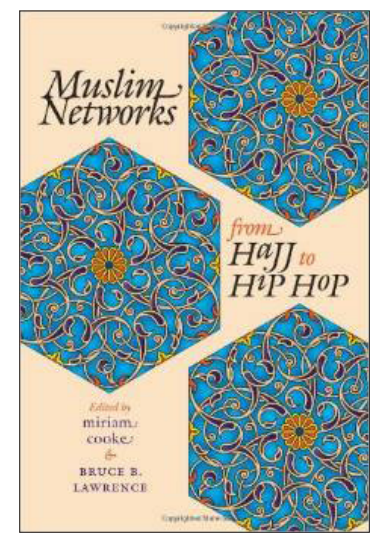

Muslim Networks from Hajj to Hip Hop. Edited by miriam cooke and Bruce B. Lawrence. Chapel Hill \& London: The University of North Carolina Press, 2005. 344 pp.

I wanted to review this book for one particular purpose: I know very little about Islam, and the title of the book suggested it could be a good place to begin. Therefore, this review should be seen from that perspective. In general, I have to admit that I was not disappointed.

The main argument of this edited volume is that networks are crucial for understanding Islam. As it appears, Muslim networks enforce a sense of community and help to create common identity on a group level, and in a larger perspective, expanding over continents and supporting the movement of ideas or people. This collection of articles focuses on the networks that are related mainly to various facets of identity, centred around the common perception of being Muslim. These identities are related to a common 
origin, religious group affiliation, gender, or political views, and stretch across time and space. The economic aspect or larger social issues are left out, but the selection of topics is diverse. Geographically the book goes beyond the Orient, discussing Muslim groups and activities in Europe, North America and the World Wide Web. From the 14th-century scholarly travels via politically motivated Mosque networks and various women's groups, to aspects of modern culture like the Internet and hip hop, the reader discovers more about the importance of spiritual interconnection within the worldwide Muslim community. These networks are flexible, in a state of constant recreation, and surprisingly vital. In short, as Taieb Belghazi writes, "we encounter the idea of Islam on the move" (p. 275).

The book is comprised of thirteen chapters, a masterly analytical introduction and an afterword. It is more than a review can grasp and therefore only selected chapters will be discussed below. As a social anthropologist, I found fascinating the view on Muslim networks presented in the Introduction by miriam cooke and Bruce B. Lawrence. Instead of looking at networks as concrete social relationships, the editors describe Muslim networks as a medium, method and metaphor defining the Muslim community ' $u m m a$ '. This approach justifies the claim that such networks are fluid, in process. In the Introduction, general network theories are avoided and the Muslim world is presented as a continuum of heterogeneous forms of identities throughout world history, in a situation where Muslims were both a dominant group and a minority. Simultaneously, the Introduction also shows how the following chapters interact with each other in order to form a coherent narrative.

The book is compiled in chronological order, starting in the Middle Ages and progressing into the 21st century. The first chapter by Vincent J. Cornell describes the travels of a 14th-century Moroccan scholar Ibn-Battuta. This chapter exposes how medieval Muslim identity differs from the modern nation state, where loyalties are defined territorially rather than philosophically. The chapter includes a brief but interesting analyses that shows how 'medieval Muslim notables resembled mafia dons' (p. 33), and how hierarchies of loyalties were structured in such states. The travels of Ibn-Battuta are also described as a process revealing the nature of Muslim networks as those of identity and loyalty. Ibn-Battuta, as a typical medieval scholar, lived in different courts, served local sultans as an expert on Islamic law and by necessity changed his patrons. During his lifetime he travelled from Maghreb to India, and in his own way he was the forefather of modern mobile scholars. This chapter points out how the Muslim world was held together by common knowledge and jurisprudence as a global spiritual community and how this spirituality was carried by men of knowledge or 'ulama'. As the author writes: "The solidarity of 'ulama' was based in part on a common education and a common epistemology" (p. 43). This made possible Ibn-Battuta's travels and activities in different regions as an expert on Quaranic law.

The next chapter is directly linked to the first one. David Gilmartin gives a detailed overview of how 'ulama' was involved in the creation of the state of Pakistan. Here the 'ulama' is shown in a different role, using modern means of communication such as print media and publications in order to foster the creation of a modern nation state. The author goes back to the 19th century and shows how structures of the British colonial empire, separation of the state from society, and the introduction of print media, created an environment different from that of the medieval state, discussed in the previous chapter. In this chapter, 'ulama' is shown as the network that instrumentalised colonial 
structures and modern means of technology in order to mobilise Muslims around the idea of a common Muslim state. Valuable are also remarks that show how, for example, Taliban and organisers of September 11 are directly linked to the networks of political mobilisation established in the 19th century.

Gender in the Muslim world is tackled in several chapters that focus on women in different regions and socio-political contexts. Tayba Hassan Al Khalifa Sharif has contributed a chapter about the Iraqi Shiite women in the Netherlands, and the meaning of the mourning ritual majlis al-qiraya, which is a ritual conducted only by women and dedicated to remembrance and mourning of the members of the Prophet's family. A reader unfamiliar with Muslim culture and specific characteristics of different religious schools finds in this chapter an excellent explanation to the main conceptual differences between Sunni and Shiite Muslims. The chapter focuses on a diasporic women's network "that projects female actors as the custodians of hope" (p. 133). Through the detailed ethnographic descriptions, the author paints an excellent picture of the ritual and atmosphere in the room. It is argued that the ritual has a therapeutic meaning for participants who link their new home in Holland not only to the Iraq prior to Iran-Iraq War but also to Iraq history. As a whole, the chapter sheds light on how Muslim refugee communities are able to establish their group solidarity around intimate rituals, using poetry and historical narratives.

The concluding research paper about the Muslim hip hop networks in the USA is rather disappointing. The author H. Samy Alim shows how different American hip hop artists use 'Islamic knowledge' and particularly the Quran to link hip hop with Islam. For someone who has conducted research on hip hop, the chapter contributes too little to what we know about the different forms and ideologies of hip hop culture. Apart from discovering that some of the most notable hip hop artists like Mos Def, Chuck D or RZA are Muslims, the reader will not find any particular new insight into the world of American Muslims and their take on hip hop. It is shown that Afro-American Muslim artists feel part of the global Muslim community 'ummah' but the chapter does not answer the question 'How?'. At the end of the chapter the author poses questions for 'further research', which are related to the process of Muslim nation building with the help of contemporary urban music culture. I hope that H. Samy Alim will have a chance to explore these issues in the concluding pages and will present us with some new and fascinating research in the future.

In general, this book is a well written and refreshing collection of individual research articles. These articles present a reading alternative to networks, discussing issues of a philosophical, religious and ideological nature rather than strategies or structures. All contributions are theoretically well founded, in some chapters unexpected links are made between different philosophers and analysis of the network. However, the most glaring attribute of the book is how readable it is for people without a deep knowledge of Islam or the Orient. Regional histories, rituals, the essence of different spiritual schools, are elegantly explained and the whole text is perfectly understandable and interesting for a non-expert. Therefore, this book is not only recommended to scholars of the Middle East, Islam, or the Orient, but also to anybody who wishes to get an insight into Muslim culture. Moreover, anybody interested in diasporas, nation building, networks, or identity construction finds in this book some solid case studies of comparative material.

Aimar Ventsel 


\section{OUR AUTHORS}

Irina Sedakova, Candidate of Sciences 1984, $\mathrm{PhD}$ in Slavic languages (2007), is a leading research fellow at the Institute for Slavic Studies, Russian Academy of Sciences, Moscow, and head of the Center for Linguo-Cultural Studies Balcanica. She has published two books and over 300 articles on Slavic and Balkan folklore, ethnolinguistics and sociolinguistics.

irina.a.sedakova@gmail.com

Laurent Sébastien Fournier is assistant professor at the University of Nantes, France. His research focuses on the transformations of traditional rituals, festivals, games and sports in Europe. He has conducted fieldwork in France and Great Britain and has acted as an expert in the field of intangible cultural heritage.

laurent.fournier@univ-nantes.fr

Ingrid Slavec Gradišnik is ethnologist and research advisor at the ZRC SAZU Institute of Slovenian Ethnology, Ljubljana, Slovenia. Her main fields of research include history and theory of ethnology and socio-cultural anthropology, methodology, cultural heritage, and ritual practices.

ingrid.slavec-gradisnik@zrc-sazu.si

Jurij Fikfak is ethnologist and cultural anthropologist, associate professor at the Institute of Slovenian Ethnology SRC SASA, Ljubljana, Slovenia. His research focuses primarily on qualitative methodology, history of scientific and common-sense discourses, and rituals.

jurij.fikfak@guest.arnes.si

Juraj Belaj is senior research associate at the Institute of Archaeology in Zagreb, Croatia. His research interests mainly revolve around mediaeval topics: from issues dealing with the presence and influence of military orders in Europe, to the interpretation of pre-Christian Slavic sacred space.

juraj.belaj@iarh.hr

Marijana Belaj is associate professor at the Department of Ethnology and Cultural Anthropology, Faculty of Humanities and Social Sciences, University of Zagreb, Croatia. Her major fields of interest are religion and politics, inter-religious dynamics, (noninstitutional) practices and processes of consecration of places, persons and time, as well as contemporary pilgrimages.

marijana@belaj.com 
Petra Kelemen is senior assistant at the Department of Ethnology and Cultural Anthropology, Faculty of Humanities and Social Sciences, University of Zagreb, Croatia. Her main research interests include anthropology of tourism, anthropology of festivals, processes of heritage construction, and contemporary Croatian migrations.

pkelemen@ffzg.hr

Filomena Sirovica is archaeologist at the Archaeological Museum in Zagreb, Croatia, and a PhD student at the Department of Archaeology, University of Ljubljana, Slovenia. Her main areas of research include archaeological methods and theory with special emphasis on the relationship between scientific and socio-political values of archaeological heritage.

filomena.sirovica@amz.hr

Nina Vlaskina is senior researcher at the Institute of Social-Economic Research and Humanities of the Southern Scientific Centre, Russian Academy of Sciences, and has a PhD in Russian linguistics from the Southern Federal University, Rostov-on-Don, Russia. Her research interests primarily concern Cossack folk calendar, cultural dynamics and traditional culture of the Nekrasov Cossacks.

nvlaskina@gmail.com

Žilvytis Šaknys is ethnologist and has a PhD in European ethnology from the Lithuanian Institute of History and the Vytautas Magnus University. His research interests are primarily concerned with the anthropology of age, ethnic processes, history of ethnology, ritual years, and minorities. He is senior research fellow at the Department of Ethnology, Lithuanian Institute of History, Lithuania.

shaknys@gmail.com 

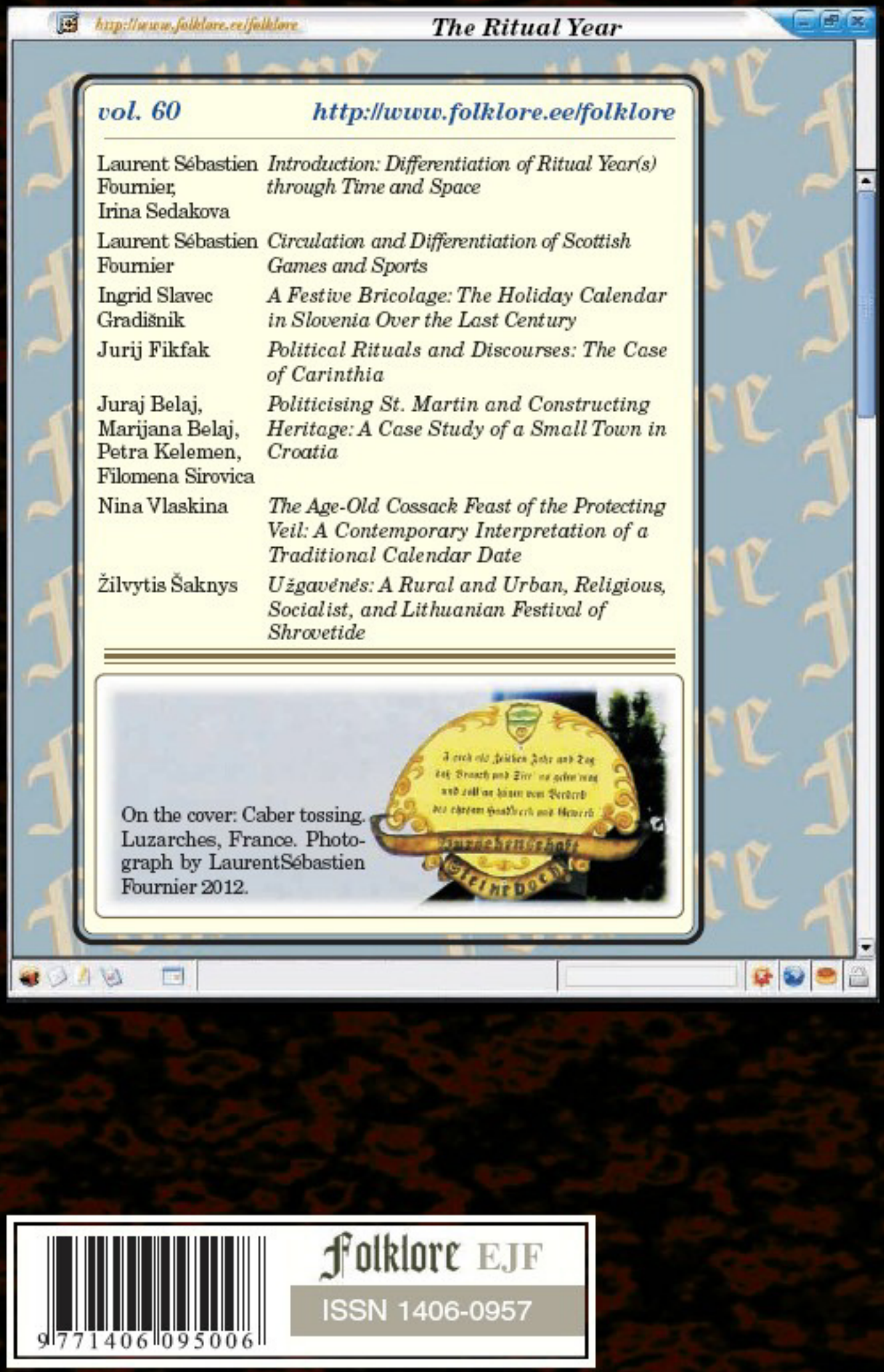